\title{
Registration Information
}

European Thyroid Journal

\section{Main Conference Fees}

\begin{tabular}{l|l|l|l}
\hline Membership status & $\begin{array}{l}\text { before } \\
\text { 30th June }\end{array}$ & $\begin{array}{l}\text { 1st July - } \\
\text { 31st August }\end{array}$ & on site \\
\hline Ordinary and Senior & $150 €$ & $175 €$ & $200 €$ \\
\hline Junior $<35$ yrs & $60 €$ & $80 €$ & $100 €$ \\
\hline Corresponding & $250 €$ & $300 €$ & $350 €$ \\
\hline Non-Member & $500 €$ & $550 €$ & $600 €$ \\
\hline Student /Res. fellow $<30$ yrs & $125 €$ & $160 €$ & $200 €$ \\
\hline Accompanying Person & $30 €$ & $40 €$ & $50 €$
\end{tabular}

Pre-Conference Events Fees

\begin{tabular}{|l|c|}
\hline ETA-CRN and ESES Meeting & $50 €$ \\
\hline ICCIDD & $40 €$ \\
\hline Ultrasonography Course & $150 €$ \\
\hline Basic Thyroid Course & free \\
\hline
\end{tabular}

\section{Day Tickets (only available on site)}

Saturday: $100 €$

Sunday, Monday, Tuesday: $150 €$ per day

Wednesday: $75 €$

\section{Main Conference Registration Entitlements}

\section{Delegate registration includes:}

- Access to all congress sessions and commercial exhibition

(according to Dutch Law, only physicians are permitted to visit the commercial exhibition)

- All congress materials and a name badge

- Programme/Abstract Book

- Lunch boxes

- Coffee breaks during the congress

- Welcome Reception

\section{Registration does not include:}

- Accommodation, tickets to the social events (unless otherwise stated) or optional excursions

\section{Accompanying person registration free includes:}

- Name badge

- Welcome Reception

- Access to the lecture halls and commercial exhibition is not included! 


\section{Pre-Conference Registration Entitlements}

ETA-CRN, ICCIDD and Ultrasonography Course and Basic Thyroid Course

Admission to the Scientific Sessions, congress material, lunch and coffee breaks

\section{Social Programme}

7th September

Welcome Reception at Hooglandse Kerk

9th September

ETA Excursion to Scheltema Complex

10th September

Gala Dinner at the National Museum of

Antiquities

On-Site Registration / Secretariat Desk / Membership Information

The Congress Registration Desk will be located in the entrance area of the Congress Centre and will operate the following hours:

\begin{tabular}{|l|l|l|}
\hline Saturday & 7th September & $07.30-19.00$ \\
\hline Sunday & 8th September & $07.30-19.00$ \\
\hline Monday & 9th September & $07.30-18.00$ \\
\hline Tuesday & 10th September & $07.30-18.00$ \\
\hline Wednesday & 11th September & $07.30-13.00$ \\
\hline
\end{tabular}

During these hours, staff at the Registration Desk can be contacted at this number: $0031(0) 715162435$.

\section{ETA Commercial Exhibition Opening Hours}

The commercial exhibition will commence on Saturday, 7th September and finish on Tuesday, 10th September.

\begin{tabular}{|l|l|l|}
\hline Set-up: & Friday, 6th September & $09.00-20.00$ \\
\hline Preliminary opening times: & Saturday, 7th September & $09.00-18.00$ \\
\hline & Sunday, 8th September & $09.00-18.00$ \\
\hline Monday, 9th September & $09.00-17.00$ \\
\hline Break-down: & Tuesday, 10th September & $09.00-18.00$ \\
\hline & Tuesday, 10th September & $18.00-22.00$ \\
\hline
\end{tabular}




\section{Floor Plan of the Congress Venue - Ground Floor}

\section{European}

\section{Thyroid Journal}

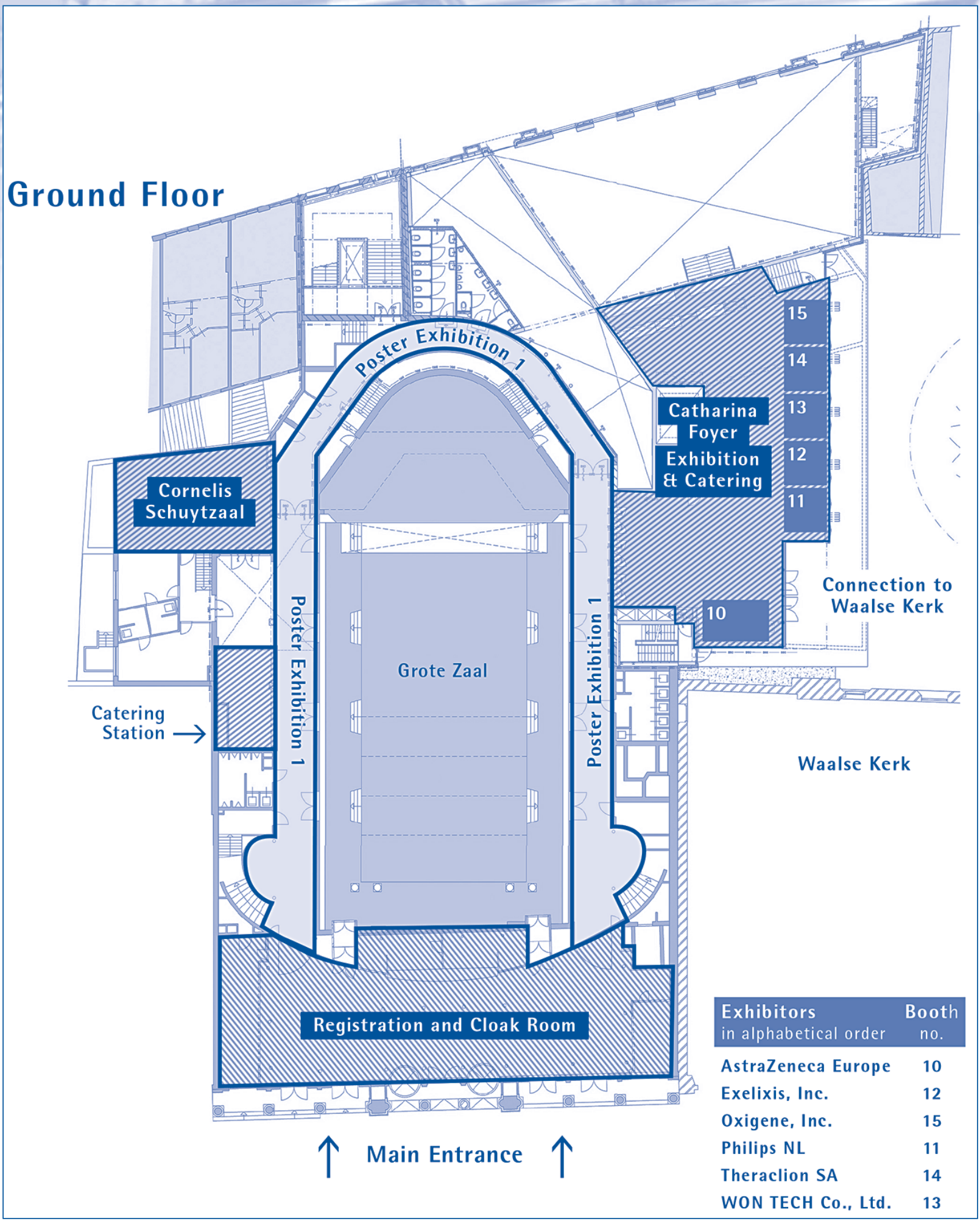




\section{European}

\section{Thyroid Journal}

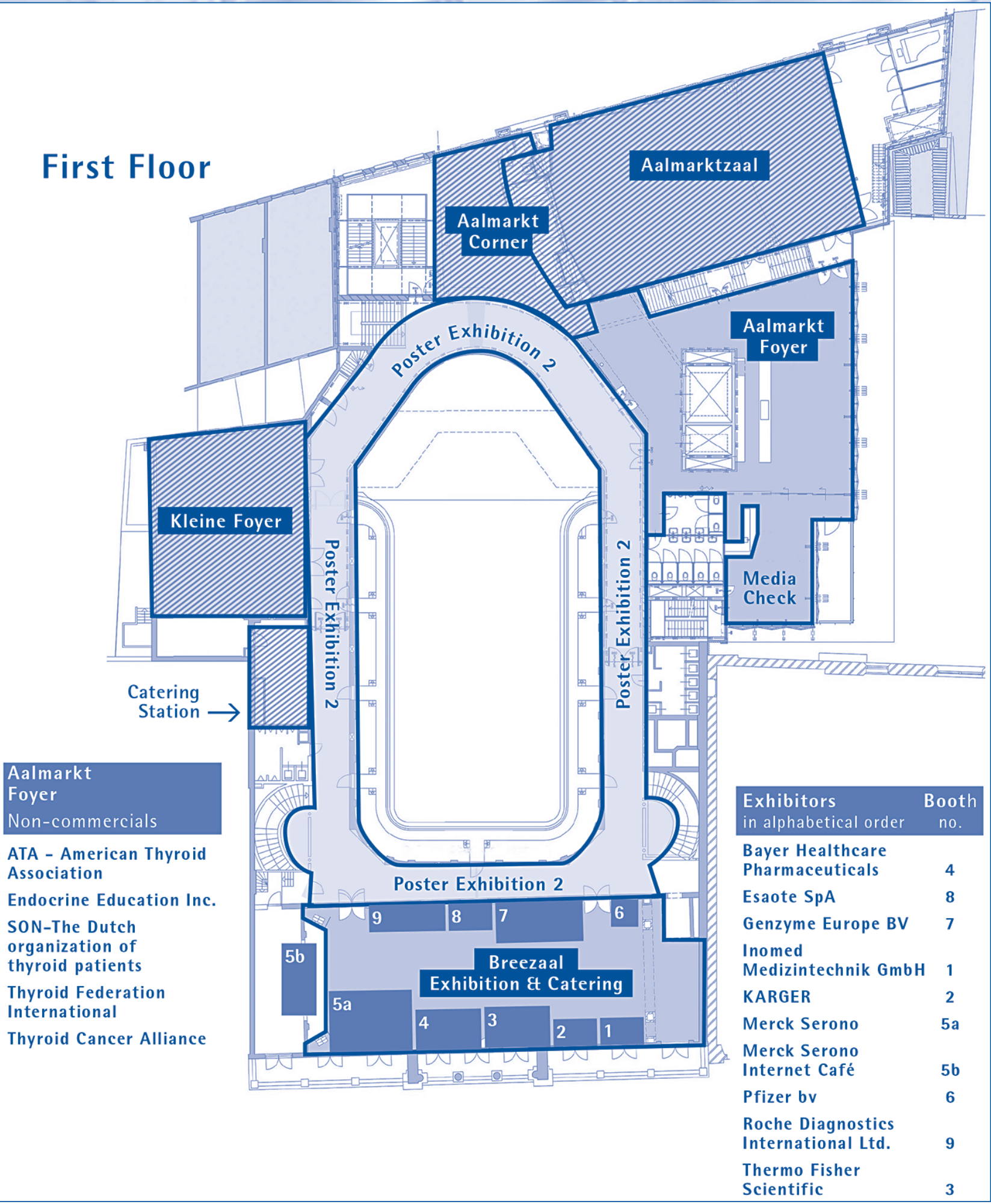




\section{Poster Exhibition Areas}

Sunday, 8th September

\begin{tabular}{|l|l|l|l|}
\hline Poster Session & $\begin{array}{l}\text { Ground Floor } \\
\text { Poster Exhibition } \\
\text { Area 1 }\end{array}$ & $\begin{array}{l}\text { First Floor } \\
\text { Poster Exhibition } \\
\text { Area 2 }\end{array}$ & $\begin{array}{l}\text { First Floor } \\
\text { Aalmarkt Corner }\end{array}$ \\
\hline PO1: Thyroid Autoimmunity Basic & Posters 01-07 & & \\
\hline PO2: Thyroid Basic & & Posters 08-17 & \\
\hline PO3: Thyroid Cancer Basic 1 & & Posters 18, 20-29 & \\
\hline PO4: Thyroid Cancer Diagnostics 1 & Posters 30-38 & & \\
\hline PO5: Thyroid Cancer Pathogenesis & Posters 39-47 & & \\
\hline PO6: Thyroid Cancer Therapeutics 1 & Posters 48-56 & & \\
\hline PO7: Case Reports 1 & & Posters 57-65 & \\
\hline PO8: Clinical Thyroidology 1 & & Posters 66-76 & \\
\hline PO9: Graves' Orbitopathy & & Posters 77-85 & Posters 86-94 \\
\hline PO10: Hyperthyroidism 1 & & & \\
\hline
\end{tabular}

Monday, 9th September

\begin{tabular}{|l|l|l|l|}
\hline Poster Session & $\begin{array}{l}\text { Ground Floor } \\
\text { Poster Exhibition } \\
\text { Area 1 }\end{array}$ & $\begin{array}{l}\text { First Floor } \\
\text { Poster Exhibition } \\
\text { Area 2 }\end{array}$ & $\begin{array}{l}\text { First Floor } \\
\text { Aalmarkt Corner }\end{array}$ \\
\hline P011: Thyroid Autoimmunity Clinical & Posters 95-104 & \\
\hline P012: Thyroid Cancer Basic 2 & $\begin{array}{l}\text { Posters 19, 105-115 \& } \\
\text { Oral 16 }\end{array}$ & \\
\hline P013: Thyroid Cancer Diagnostics 2 & Posters 116-124 & \\
\hline P014: Thyroid Nodules \& Goitre 1 & & Posters 125-132 \\
\hline P015: Thyroid Cancer Therapeutics 2 & & Posters 133-141 & \\
\hline P016: Case Reports 2 & & Posters 142-150 & Posters 151-156 \& 158 \\
\hline P017: Clinical Thyroidology 2 & & Posters 159-166 \\
\hline $\begin{array}{l}\text { P018: Environmental Influences on } \\
\text { Thyroid Function }\end{array}$ & & Posters 167-175 \\
\hline P019: Hyperthyroidism 2 & & Posters 176-183 \\
\hline P020: Hypothyroidism & & \\
\hline
\end{tabular}


Tuesday, 10th September

\begin{tabular}{|l|l|l|l|}
\hline Poster Session & $\begin{array}{l}\text { Ground Floor } \\
\text { Poster Exhibition } \\
\text { Area 1 }\end{array}$ & $\begin{array}{l}\text { First Floor } \\
\text { Poster Exhibition } \\
\text { Area 2 }\end{array}$ & $\begin{array}{l}\text { First Floor } \\
\text { Aalmarkt Corner }\end{array}$ \\
\hline PO21: Thyroid Cancer Diagnostics 3 & Posters 184-192 & \\
\hline PO22: Thyroid Cancer Diagnostics 4 & Posters 193-201 & \\
\hline PO23: Thyroid Cancer Therapeutics 3 & Posters 202-210 & \\
\hline PO24: Thyroid Cancer Therapeutics 4 & Posters 211-218 & & Posters 219, \\
\hline PO25: Case Reports 3 & & 221-227 \\
\hline PO26: Imaging & & Posters 228-231, & 233-237 \\
\hline $\begin{array}{l}\text { PO27: Thyroid Hormone Metabolism } \\
\text { and Action }\end{array}$ & & Posters 238-249 & \\
\hline PO28: Medullary Thyroid Cancer & & Posters 250-257 & \\
\hline PO29: Thyroid Nodules \& Goitre 2 & & Posters 259-266 & \\
\hline $\begin{array}{l}\text { PO30: Thyroid in Reproduction \& } \\
\text { Development }\end{array}$ & & Posters 267-275 & \\
\hline
\end{tabular}


Grote Zaal/Main Auditorium

08.30-15.15

ETA-Cancer Research Network (CRN) Meeting

in cooperation with the European Society of Endocrine Surgeons \& the European Association of Nuclear Medicine

\section{Kleine Foyer}

08.15-15.00

Advanced Thyroid, Neck Ultrasonography \& Ultrasound-Assisted Procedures

\section{Satellite Meeting on Thyroid Ultrasonography with} Live Session

\section{Aalmarkt Zaal}

08.00-15.45

\section{ICCIDD Global Network West-Central Europe Regional Meeting}

De Waag (Corner Aalmarkt/Mandenmakerssteeg) 10.00-15.30

\section{Basic Thyroid Course}

\section{Cornelis Schuytzaal}

12.00-13.00

\section{TFI Doctors-Patients Workshop}

A Joint Workshop from the Thyroid Federation International (TFI) and the Dutch Organization of Thyroid Patients (SON)

1. Short talk by a representative from the TFI Board about how TFI came to be and about its objectives and activities (10 minutes)

2. Short talk by a representative from SON about its objectives and activities (10 minutes)

3. Discussion: 'Do's and Don'ts' of setting up a Patient Organization (10 minutes)

4. Question time (30 minutes) 


\section{ETA-Cancer Research Network (CRN) Meeting}
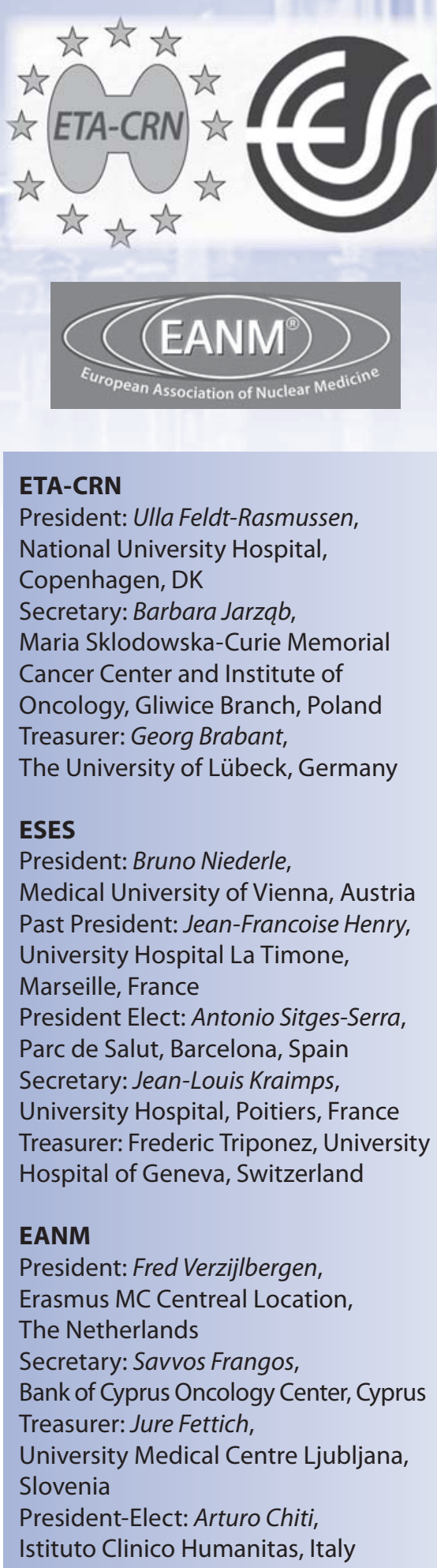

\section{ESES}

President: Bruno Niederle, Medical University of Vienna, Austria Past President: Jean-Francoise Henry, University Hospital La Timone, Marseille, France

President Elect: Antonio Sitges-Serra, Parc de Salut, Barcelona, Spain Secretary: Jean-Louis Kraimps, University Hospital, Poitiers, France Treasurer: Frederic Triponez, University Hospital of Geneva, Switzerland

\section{EANM}

President: Fred Verzijlbergen, Erasmus MC Centreal Location, The Netherlands

Secretary: Savvos Frangos, Bank of Cyprus Oncology Center, Cyprus Treasurer: Jure Fettich, University Medical Centre Ljubljana, Slovenia President-Elect: Arturo Chiti, Istituto Clinico Humanitas, Italy

in cooperation with:

European Society of Endocrine Surgeons (ESES)

European Association of Nuclear Medicine (EANM)

\section{Grote Zaal/Main Auditorium}

08.30-15.15

\section{Clinical Trials in Thyroid Cancer: An Update and Call for Further Studies}

08.30-08.50 Registration and coffee

08.50-09.00 Presidential address

\section{Session 1 Nuclear Medicine Treatment in Europe}

Chairperson: Ulla Feldt-Rasmussen, Denmark

09.00-09.45 The HiLo trial results: an update

Ujjal K. Mallick, UK

10.00-10.45 ESTIMABL trial in low risk differentiated thyroid cancer: an update Sophie Leboulleux, France

11.00-11.45 How the HiLo study and ESTIMABL study have influenced the nuclear medicine practice in Europe?

Markus Luster, Germany

\subsection{5-12.15 Discussion}

12.15-13.00 Lunch break

Session 2 Surgery of Thyroid Cancer: Prophylactic Lymphadenectomy in Papillary Thyroid Cancer - Pros and Cons

Chairpersons: Marcin Barczynski, Poland; Radu Mihai, United Kingdom

13.00-13.30 Prophylactic lymphadenectomy in papillary thyroid cancer: rationale and complications

Juan José Sancho, Spain

13.45-14.15 Feasibility of clinical trial for prophylactic lymphadenectomy in thyroid cancer Agnieszka Czarniecka, Poland

14.15-14.45 'Insight in the quality of care for patients with thyroid cancer': update of the project in The Netherlands and discussion about the future European collaboration in this field Ad Hermus, The Netherlands

14.45-15.15 General comments and discussion

15.15-16.00 ETA-CRN General Assembly. Elections of the ETA-CRN Board 


\section{Advanced Thyroid, Neck Ultrasonography \&}

\section{Ultrasound-Assisted Procedures}

\section{Satellite Meeting on Thyroid Ultrasonography with Live Session}

\section{Kleine Foyer \\ 08.15-15.00}

08.15-08.30 Introduction

Jan Smit, The Netherlands and Paolo Vitti, Italy

Thyroid Ultrasound (US) Guided Fine Needle Aspiration (FNA)

Chairperson: Paolo Vitti

08.30-08.45 Basics \& history of US in endocrine clinics; advantages, disadvantages and pitfalls

Murat Erdogan, Turkey

08.45-09.00 Doppler sonography and elastosonography in thyroid nodules.

Different results and comparison of different equipment

Teresa Rago, Italy

09.00-09.15 US guided FNA procedure; advantages, disadvantages and pitfalls? Enrico Papini, Italy

Ultrasound Management of Multinodular Goiter

Chairperson: Paolo Vitti

09.15-10.45 Interactive case illustrations on video presentations.

Laurence Leenhardt, Teresa Rago, Enrico Papini, Gilles Russ,

Alptekin Gürsoy, Herve Monpeyssen, Steen J. Bonnema

10.45-11.15 Coffee break

\section{Ultrasound Management of Thyroid Cancer}

Chairperson: Murat Erdogan

11.15-11.30 Undetected carcinomas: learning from one's mistakes

Gilles Russ, France

11.30-11.45 Ultrasound guidelines for the follow up of thyroid cancer Laurence Leenhardt, France

11.45-12.15 Mini-invasive treatment procedures (PEl and thermal ablation) for thyroid nodules and metastatic cervical lymph nodes

Laszlo Hegedüs, Denmark

12.15-13.30 Lunch break

$13.30-15.00$

Live Session, Video Presentations of Clinical Cases, US Procedures and Take Home Messages

Chairperson: Laurence Leenhardt

- The Italian team (Teresa Rago, Enrico Papini, Paolo Vitti)

- The French team (Gilles Russ, Herve Monpeyssen, Laurence Leenhardt)

- The Turkish team (Alptekin Gürsoy, Murat Erdoğan)

- The Danish team (Steen J. Bonnema, Laszlo Hegedüs)

Kindly sponsored by Esaote, Benelux and Philips, The Netherlands 


\section{ICCIDD Global Network West-Central Europe Regional Meeting}

\section{Aalmarktzaal, First Floor, City Music Hall, Leiden \\ 08.00-15.45}

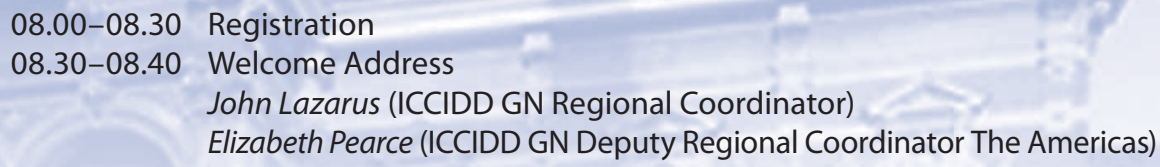

\section{Scientific Symposium \\ Section 1 \\ Chairmen: Paolo Vitti (Italy) \\ John Lazarus (UK)}

08.40-08.55 Effects of maternal thyroid state and iodine intake on development of the offspring

Marco Medici (The Netherlands)

ICCIDD

08.55-09.00 Discussion

09.00-09.15 Mild iodine deficiency and neurocognitive outcomes

Peter Taylor (UK)

09.15-09.20 Discussion

09.20-09.35 The Norwegian mother and child cohort study Helle Margrete Meltzer (Norway)

09.35-09.40 Discussion

09.40-09.55 Coffee break

\section{Section 2}

Chairmen: Peter Smyth (Ireland)

Elizabeth Pearce (Deputy Regional Coordinator The Americas)

09.55-10.10 The iodine cycle and IDD protection

Alex Stewart (UK)

10.10-10.15 Discussion

10.15-10.30 Serum thyroglobulin as a biomarker for iodine deficiency Tomislav Jukic (Croatia)

10.30-10.35 Discussion

10.35-10.50 Salt reduction/salt iodisation Ludmila Ivanova (Bulgaria)

10.50-10.55 Discussion

10.55-11.25 Aldo Pinchera Memorial Lecture Professor Paolo Vitti (Italy)

11.25-12.15 Lunch and Poster Viewing 
Section 3

lodine Nutrition Status in West and Central Europe:

An Update on Present Status and Future Developments

12.15-12.25 Introduction

John Lazarus (UK)

12.25-13.55 Presentation of Country Data: ICCIDD GN National Representatives Chairmen: John Lazarus (ICCIDD West \& Central Europe Regional Coordinator) Murat Erdogan (Turkey)

\begin{abstract}
Albania - Agron Ylli
Bulgaria - Ludmilla Ivanova

Croatia - Zvonko Kusic

Cyprus - Georgios Georgiades

Denmark - Peter Laurberg

Estonia - Toomas Podar

Finland - Matti Valimaki

France - Phillipe Caron

Germany - Henry Volzke

Greece - Kostas Markou

Hungary - Endre Nagy

Ireland - Peter Smyth

Israel - Aron Troen

Italy - Paolo Vitti
\end{abstract}

Belgium - Rodrigo Moreno-Reyes

Bosnia Herzegovina - Amela Lolic

Czech Republic - Vaclav Zamrazil

\title{
13.55-14.10 Coffee break
}

14.10-15.45 Presentation of Country Data: ICCIDD GN National Representatives Chairmen: Paolo Vitti (ICCIDD West \& Central Europe Deputy Regional Coordinator) Peter Laurberg (Denmark)

\author{
Latvia - Valdis Pirags \\ Lithuania - Albertas Barzda \\ Luxembourg - Yolande Wagener \\ Macedonia - Borislav Karafilski \\ The Netherlands - Robin Peeters \\ Norway - Lisbeth Dahl \\ N. Cyprus - Hasan Sav \\ Poland - Zbigniew Szybinski \\ Portugal - Edward Limbert \\ Romania - Mihaela Simescu \\ Serbia - Bozo Trbojevic \\ Slovakia - Jan Podoba \\ Slovenia - Segej Hojker \\ Spain - Lluis Vila \\ Sweden - Mehari Gebre-Medhin \\ Switzerland - Michael Zimmermann \\ Turkey - Murat Erdogan \\ United Kingdom - Mark Vanderpump
}

\section{ICCIDD GLOBAL NETWORK}

Regional Coordinator West and Central Europe: John Lazarus

Deputy Regional Coordinator: Paolo Vitti

Secretariat ICCIDD GN West Central Europe E-Mail: ICCIDD@cf.ac.uk 


\section{Basic Thyroid Course}

\section{De Waag (Corner Aalmarkt/Mandenmakerssteeg) \\ 10.00-15.30}

Thyroid Development, Function and Carcinogenesis

Session 1

Chairpersons: Josef Köhrle, Germany; Theo J. Visser, The Netherlands

10.00-10.30 Thyroid anatomy and hormone production

Patrice Rodien, France

10.30-11.00 Regulation of the hypothalamus-pituitary-thyroid axis Eric Fliers, The Netherlands

11.00-11.30 Thyroid gland embryology Roberto Di Lauro, Italy

11.30-12.00 From stem cells to thyroid gland Sabine Costagliola, Belgium

12.00-12.30 Discussion

12.30-13.00 Lunch break

\section{Session 2}

Chairpersons: Clara Alvarez, Spain; Luca Persani, Italy

13.00-13.30 Congenital hypothyroidism: defects in thyroid gland development Heiko Krude, Germany

13.30-14.00 Signaling pathways in the thyroid gland Pilar Santisteban, Spain

14.00-14.30 Molecular causes of thyroid cancer Massimo Santoro, Italy

14.30-15.00 Thyroid development and carcinogenesis: reciprocal processes? Mikael Nilsson, Sweden

15.00-15.30 Discussion

$15.30 \quad$ End 


\section{European}

\section{Thyroid Journal}

\section{Scientific Programme}

Saturday, 7th September 2013

\section{Grote Zaal/Main Auditorium \\ $16.00-18.00$ \\ „MerckSerono \\ Living science, transforming lives}

Merck Serono Symposium

\section{The Impact of Hypothyroidism in Daily Life}

Chairperson: Leonidas Duntas, Greece

Co-Chairperson: Luigi Bartalena, Italy

16.00 Welcome Introduction

Leonidas Duntas, Greece

16.10 Hypothyroidism during pregnancy and the post-partum

Victor Pop, The Netherlands

16.35 Neuroendocrine and cognitive impact of hypothyroidism

Peter Laurberg, Denmark

17.00 Association of high TSH level with obesity and thyroid cancer risk

Furio Pacini, Italy

17.25 Morbidity and mortality of hypothyroidism

George J. Kahaly, Germany

17.50 Closing remarks

Luigi Bartalena, Italy 


\section{Grote Zaal/Main Auditorium}

18.00-18.15

\section{Opening Ceremony}

Welcome by Theo Visser and Jan Smit

\section{Grote Zaal/Main Auditorium \\ 18.15-19.00}

The European Thyroid Journal Lecture

Chair: Wilmar M. Wiersinga, The Netherlands

Editor-in-Chief of the European Thyroid Journal

Disorders of thyroid hormone action: insights from human genetics

Krishna Chatterjee, UK

\subsection{0-21.00 Welcome Reception (Hooglandse Kerk)}

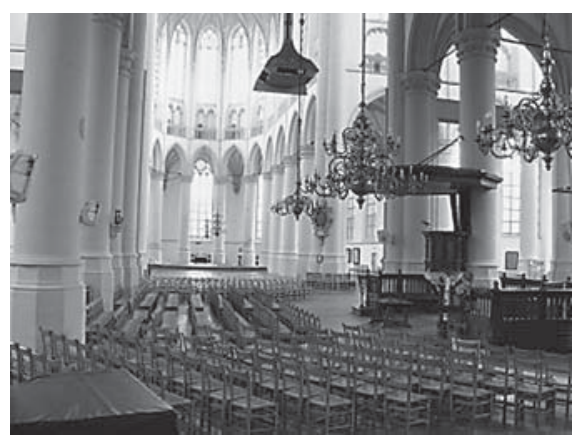




\section{Scientific Programme - Oral Sessions}

\section{European Thyroid Journal}

\section{Sunday, 8th September 2013}

Grote Zaal/Main Auditorium

\section{$08.00-10.00$ \\ Oral Session 1: \\ Topic Highlights (OP01-OP06) \\ Chairpersons: Theo Visser, The Netherlands \\ Jan Smit, The Netherlands}

\subsection{0-08.20}

OP01 EFFICACY OF CABOZANTINIB IN A PHASE 3 STUDY OF MEDULLARY THYROID CANCER (MTC) PATIENTS WITH RET OR RAS MUTATIONS

Sherman $\mathrm{SI}^{1}$, Cohen $E E W^{2}$, Schöffski $P^{3}$, Elisei $R^{4}$, Schlumberger $M^{5}$, Wirth $L^{6}$, Mangeshkar $M^{7}$, Aftab $\mathrm{DT}^{7}$, Clary $D \mathrm{O}^{7}$, Brose $\mathrm{M}^{8}$

${ }^{1}$ University Texas MD Anderson Cancer Center, Houston, United States, ${ }^{2}$ University of Chicago, Chicago, United States,

${ }^{3}$ University Hospitals Leuven, KU Leuven, Leuven, Belgium,

${ }^{4}$ University of Pisa, Pisa, Italy, ${ }^{5}$ Institut Gustave Roussy, University Paris-Sud, Villejuif, France, ${ }^{6}$ Massachusetts General Hospital, Boston, United States, ${ }^{7}$ Exelixis, Inc., South San Francisco, United States, ${ }^{8}$ University of Pennsylvania Health System, Philadelphia, United States

08.20-08.40

OP02 A RANDOMIZED, DOUBLE-BLIND, PLACEBOCONTROLLED PHASE III TRIAL (DECISION) OF SORAFENIB IN LOCALLY ADVANCED OR METASTATIC PATIENTS WITH PROGRESSIVE RADIOACTIVE IODINE-REFRACTORY DIFFERENTIATED THYROID CANCER

Schlumberger $M^{1}$, Jarzab $B^{2}$, Elisei $R^{3}$, Siena $S^{4}$, Bastholt $L^{5}$, de la Fouchardiere $C^{6}$, Pacini $F^{7}$, Paschke $R^{8}$, Worden $F^{9}$, Bockisch $A^{10}$, Nutting $\mathrm{C}^{11}$, Shong $Y K^{12}$, Sherman $\mathrm{SI}^{13}$, Smit JWA ${ }^{14}$, Chung ${ }^{15}$, Kappeler $\mathrm{C}^{16}$, Molnar ${ }^{15}$, Brose $\mathrm{MS}^{17}$

${ }^{1}$ Institut Gustave Roussy, Villejuif, France, ${ }^{2}$ Maria SklodowskaCurie Memorial Cancer Centre and Institute of Oncology, Gliwice, Poland, ${ }^{3}$ University of Pisa, Department of Clinical and Experimental Medicine, Pisa, Italy, ${ }^{4}$ Ospedale Niguarda $\mathrm{Ca}^{\prime}$ Granda, Milan, Italy, ${ }^{5}$ Odense University Hospital, Odense, Denmark, ${ }^{6}$ Hospices Civils-Centre Anticancéreux, Consortium Cancer Thyroïdien, Lyon, France, ${ }^{7}$ University of Siena, Unit of Endocrinology, Siena, Italy, ${ }^{8}$ Leipzig University, Department for Endocrinology and Nephrology, Leipzig, Germany, ${ }^{9}$ University of Michigan Health System, Ann Arbor, United States,
${ }^{10}$ Universitätsklinikum Essen-Radiologie, Essen, Germany,

${ }^{11}$ Royal Marsden Hospital, London, United Kingdom,

${ }^{12}$ University of Ulsan College of Medicine, Asan Medicine Center, Seoul, Republic of Korea, ${ }^{13}$ The University of Texas MD Anderson Cancer Center, Houston, United States, ${ }^{14}$ Radboud University Nijmegen Medical Center, Department of Internal Medicine, Nijmegen, Netherlands, ${ }^{15}$ Bayer HealthCare Pharmaceuticals, Montville, United States, ${ }^{16}$ Bayer Pharma AG, Berlin, Germany, ${ }^{17}$ University of Pennsylvania Health, Abramson Cancer Center, Philadelphia, United States

08.40-09.00

\section{OP03 INAPPROPRIATE HEAT DISSIPATION IGNITES} BROWN FAT THERMOGENESIS IN MICE WITH A MUTANT THYROID HORMONE RECEPTOR a1

Warner $A^{1}$, Rahman $A^{2}$, Gottschling $K^{1}$, Davis $B^{2}$, Vennström $B^{1}$, Arner $A^{2}$, Mittag J

${ }^{1}$ Karolinska Institutet, Department of Cell and Molecular Biology, Stockholm, Sweden, ${ }^{2}$ Karolinska Institutet, Department of Physiology and Pharmacology, Stockholm, Sweden

09.00-09.20

OP04 A NOVEL MECHANISM OF TBG DEFICIENCY: MUTATION IN A LIVER SPECIFIC TRANSCRIPTION ENHANCER

Ferrara $A M^{1}$, Dumitrescu $A M^{1}$, Brown $C D^{2}$, Peterson $A^{2}$, Moeller $L C^{3}$, Wyne $K^{4}$, White KP2, Weiss RE ${ }^{1,5}$, Refetoff $S^{1,5,6}$ ${ }^{1}$ University of Chicago, Medicine, Chicago, United States, ${ }^{2}$ University of Chicago, Human Genetics, Chicago, United States, ${ }^{3}$ University of Duisburg-Essen, Endcrinology and Metabolic Diseases, Essen, Germany, ${ }^{4}$ Weill Cornell Medical College, The Methodist Hospital, Medicine, Houston, United States, ${ }^{5}$ University of Chicago, Pediatrics, Chicago, United States, ${ }^{6}$ University of Chicago, Committee of Genetics, Chicago, United States

$09.20-09.40$

OP05 DICER1 PLAYS A CRUCIAL ROLE IN THYROID FUNCTION AND GOITER DEVELOPMENT IN MICE Undeutsch $H^{1}$, Löf $C^{1}$, Pakarinen $P^{1}$, Poutanen $M^{1}$, Kero $J^{1}$ ${ }^{1}$ University of Turku, Department of Physiology, Turku, Finland 
A Satellite Symposium Held in Conjunction With the $37^{\text {th }}$ Annual Meeting of the European Thyroid Association
This activity is sponsored by prIME Oncology.

\section{TARGETED THERAPY FOR}

\section{ADVANCED MEDULLA
THYROID CANCER: \\ PRACTICAL ADVICE FOR CLINICIANS}

\section{Sunday, 8 September 2013 13.00-14.00}

Grote Zaal/Main Auditorium

City Music Hall (Stadsgehoorzaal)

Breestraat 60

2311 CS Leiden

the Netherlands

CHAIR

Thera P. Links, MD, PhD

University Medical Centre Groningen

Groningen, the Netherlands

\section{FACULTY}

Lars Bastholt, MD

Odense University Hospital

Odense, Denmark

Martin Schlumberger, MD

Institute Gustave-Roussy

Villejuif, France

\section{Y}

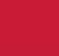


09.40-10.00

OP06 GENOME-WIDE MICRORNA EXPRESSION ANALYSIS

OF THYROID CANCER BY NEXT GENERATION SEQUENCING IDENTIFIES MICRORNAS INVOLVED IN THYROID DIFFERENTIATION

Riesco-Eizaguirre $G^{1,2}$, Wert $L^{2}$, Santisteban $P^{2}$

${ }^{1}$ Hospital Universitario La Paz (IdiPaz), Endocrinology, Madrid, Spain, ${ }^{2}$ Instituto de Investigaciones Biomédicas (CSIC-UAM),

Madrid, Spain

10.00-10.30 Coffee break

Aalmarkt Zaal

$10.30-12.00$

Symposium 1 (Basic): Thyroid Hormone

Regulation in Brain

Chairpersons: Juan Bernal, Spain

Anita Boelen, The Netherlands

$10.30-11.00$

Role of Dio2 in the HPT axis

Antonio Bianco, USA

11.00-11.30 Cell-specific function of TRa Frédéric Flamant, France

11.30-12.00 Role of Dio3 in brain development Arturo Hernandez, USA

Grote Zaal/Main Auditorium

10.30-12.00

Symposium 2 (Clinical): Imaging and Thyroid Incidentaloma

Chairpersons: Paolo Vitti, Italy

Romana Netea-Maier, The Netherlands

10.30-11.00 Epidemiological aspects: the size of the problem

Sophie Leboulleux, France

11.00-11.30 Risk stratification by ultrasound Gilles Russ, France

11.30-12.00 Management of thyroid incidentaloma Laszlo Hegedüs, Denmark

Poster Area

12.00-13.00

Lunch and Poster Discussion 1 (Posters 1-94*)

* poster 19 will be presented on Monday in Poster Session 12 (see pages 39 to 47 )

Poster Session 1: Thyroid Autoimmunity Basic

Chairperson: Paul Banga, UK

Poster Session 2: Thyroid Basic

Chairperson: Josef Köhrle, Germany

Poster Session 3: Thyroid Cancer Basic 1

Chairperson: Rosa Marina Melillo, Italy
Poster Session 4: Thyroid Cancer Diagnostics 1

Chairperson: Sophie Leboulleux, France

Poster Session 5: Thyroid Cancer Pathogenesis

Chairperson: Cristina Romei, Italy

Poster Session 6: Thyroid Cancer Therapeutics 1

Chairperson: Christine Spitzweg, Germany

Poster Session 7: Case Reports 1

Chairperson: Istvàn Szabolcs, Hungary

Poster Session 8: Clinical Thyroidology 1

Chairperson: Murat Erdogan, Turkey

Poster Session 9: Graves' Orbitopathy

Chairperson: Anja Eckstein, Germany

Poster Session 10: Hyperthyroidism 1

Chairperson: Mario Salvi, Italy

\section{Grote Zaal/Main Auditorium}

13.00-14.00

\section{AstraZeneca}

prIME Oncology Satellite Symposium supported by AstraZeneca

Targeted Therapy for Advanced Medullary Thyroid Cancer (MTC): Practical Advice for Clinicians

Welcome and introduction

Thera P. Links, The Netherlands

13.00 The when, what, and how of targeted therapy for MTC in 2013

Martin Schlumberger, France

13.15 Clinical scenario \#1-Symptomatic metastatic MTC in 2013: Using the right treatment for the right patient at the right time Lars Bastholt, Denmark

13.35 Clinical scenario \#2-Progressive metastatic MTC following first-line tyrosine kinase inhibitor therapy: A look forward Thera P. Links, The Netherlands

13.55 Symposium "pearls" and concluding remarks Thera P. Links, The Netherlands

14.00 Adjourn 


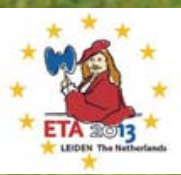

A BAYER HEALTHCARE-SPONSORED SATELLITE SYMPOSIUM AT THE D

37TH ANNUAL MEETING OF THE EUROPEAN THYROID ASSOCIATION

The Road Ahead in Differentiated
Thyroid Cancer in Differentialec
Thyroid Cancer
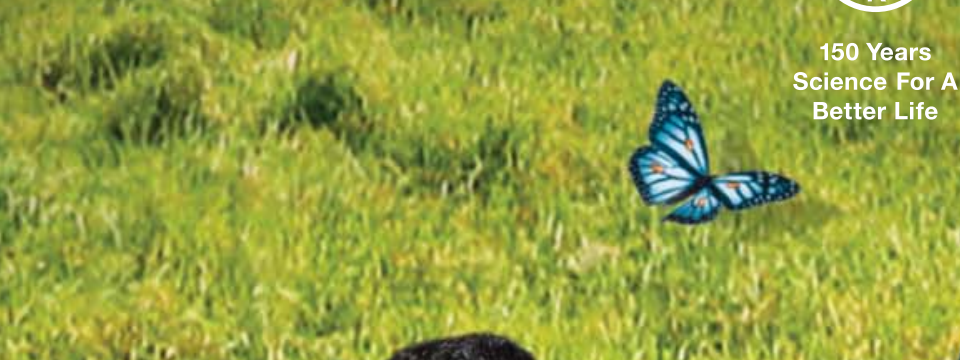
4at)
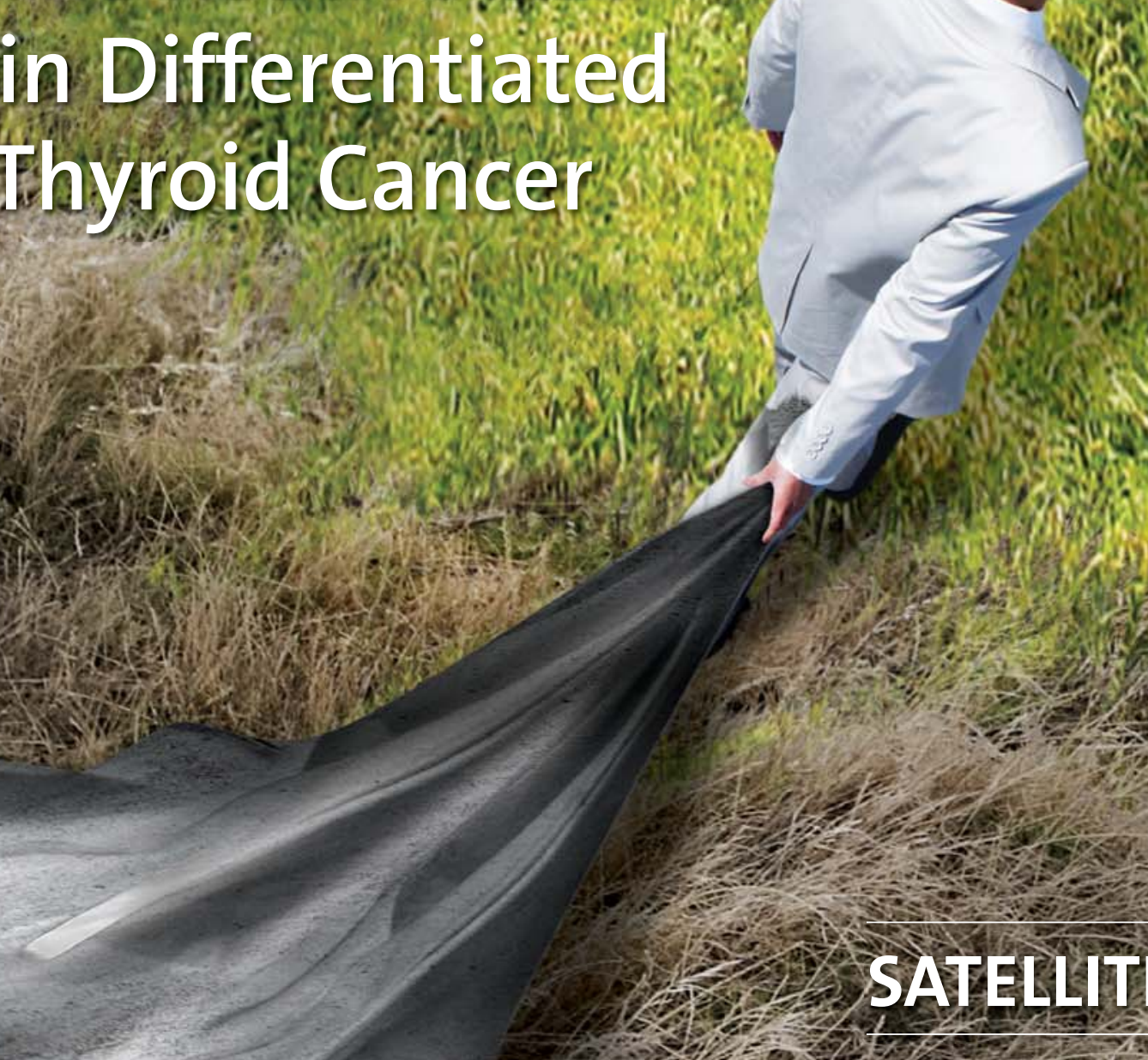

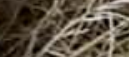

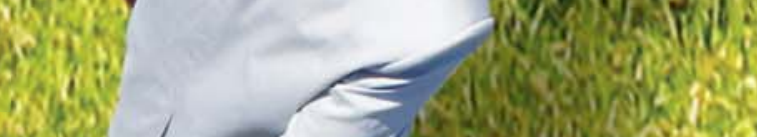

900 ing

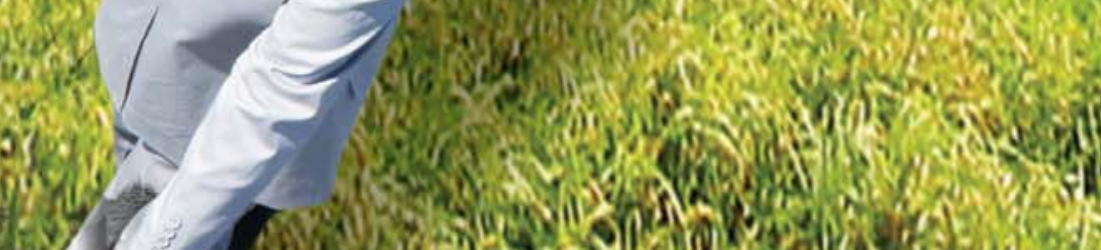

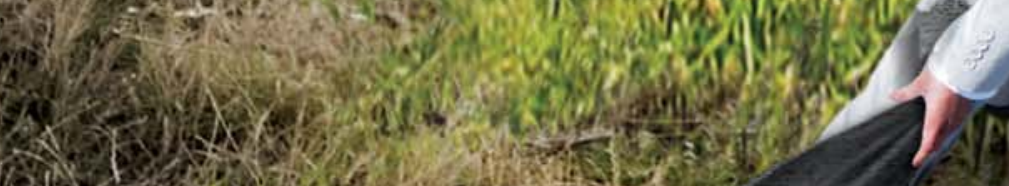

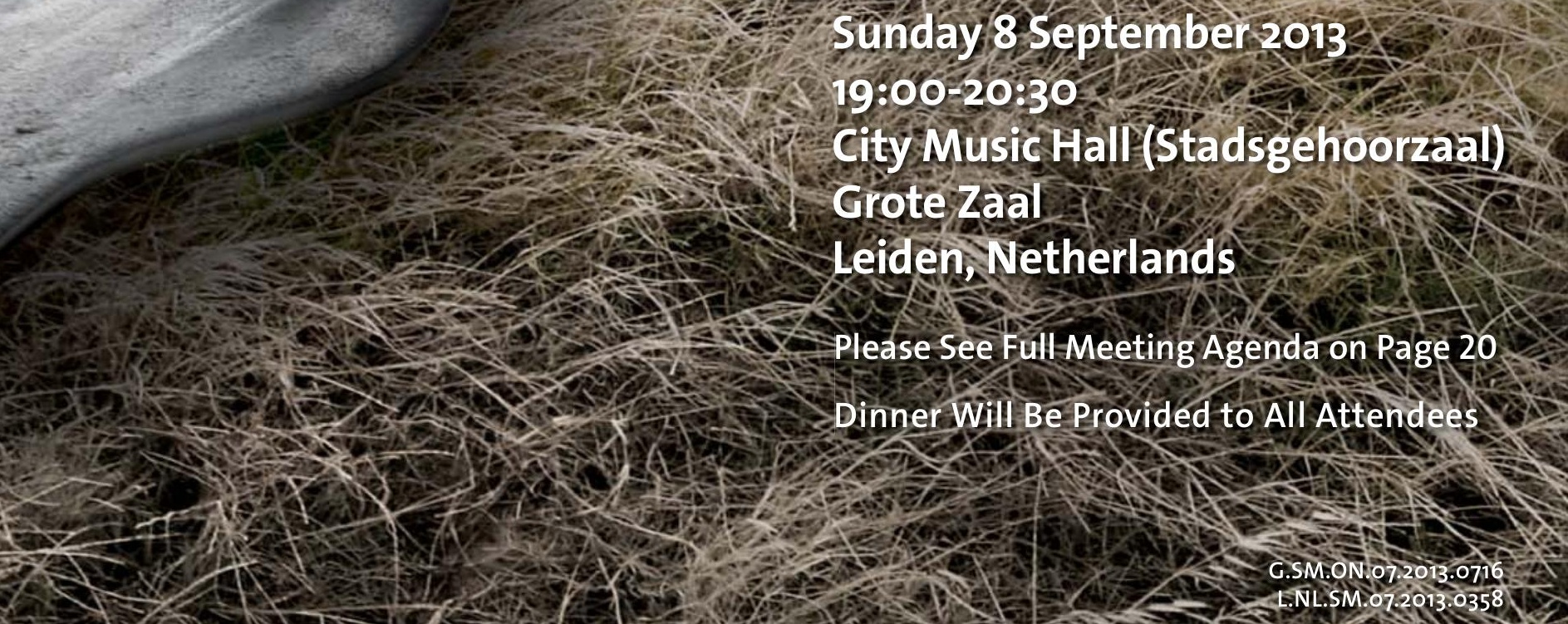

Sinday 8 september 2013 $19: 00=2030$

City Music Hall (Stadsgehoorzal) Grote zaa Leiden, Netherlands

Please see Full-Meeting Agenda on Page 20 
14.00-14.45

Meet the Expert 1-4

\section{Kleine Foyer}

$14.00-14.45$

MTE 1 (Basic)

Transcriptional regulation in thyroid Josef Köhrle, Germany

Waalse Kerk

$14.00-14.45$

MTE 2 (Translational)

Thyroid hormone and lipid metabolism

Pieter de Lange, Italy

\section{Grote Zaal/Main Auditorium}

$14.00-14.45$

MTE 3 (Clinical)

ETA guidelines on TSH-secreting adenomas

Paolo Beck-Peccoz, Italy

Aalmarkt Zaal

$14.00-14.45$

MTE 4 (Clinical)

Assisted reproduction and thyroid dysfunction Kris Poppe, Belgium

$14.45-15.15$

Coffee break

Grote Zaal/Main Auditorium

15.15-15.45

\section{Harington-de Visscher Prize Lecture}

Chairpersons: Theo Visser, The Netherlands

Luigi Bartalena, Italy

Clinical consequences of variation in thyroid hormone pathway genes

Robin Peeters, The Netherlands

\section{Grote Zaal/Main Auditorium}

$16.00-18.00$

Oral Session 2:

Young Investigators Session (OP07-OP14)

Chairpersons: Furio Pacini, Italy Graham Williams, UK
$16.00-16.15$

OP07 LOW BIRTH WEIGHT IN CHILDREN BORN TO MOTHERS WITH HYPERTHYROIDISM AND HIGH BIRTH WEIGHT IN HYPOTHYROIDISM, WHEREAS PRETERM BIRTH IS COMMON IN BOTH CONDITIONS: A DANISH NATIONAL HOSPITAL STUDY OF $1,638,338$ CHILDREN AND THEIR MOTHERS

Andersen $S L^{1}$, Olsen $\mathcal{S}^{2}, W u \mathrm{CS}^{2}$, Laurberg $P^{1}$

${ }^{1}$ Aalborg University Hospital, Department of Endocrinology,

Aalborg, Denmark, ${ }^{2}$ Aarhus University, Section for

Epidemiology, Department of Public Health, Aarhus,

Denmark

16.15-16.30

OP08 GRAVES' ORBITOPATHY IN MICE WITH

THYROTROPIN RECEPTOR PLASMID ELECTROPORATION, CHARACTERISED BY RETROBULBAR INFLAMMATION, ADIPOGENESIS, FIBROSIS AND OCULAR MANIFESTATIONS OF ACUTE CONGESTIVE OPHTHALMOPATHY

Moshkelgosha S ${ }^{1}$, So P-W' ${ }^{2}$, Deasy $N^{3}$, Diaz-Cano $S^{4}$, Banga JP ${ }^{1}$

${ }^{1}$ King's College London School of Medicine, Diabetes and Endocrinology, London, United Kingdom, ${ }^{2}$ King's College London School of Medicine, Institute of Psychiatry, Preclinical Imaging Unit, London, United Kingdom, ${ }^{3}$ Institute of Psychiatry, Neuroradiology, London, United Kingdom, ${ }^{4}$ King's College Hospital NHS Trust, Pathology, London, United Kingdom

$16.30-16.45$

OP09 MATERNAL HYPOTHYROXINEMIA AND TPO ANTIBODIES, BUT NOT HIGH TSH LEVELS, ARE RISK FACTORS FOR PREMATURITY: THE GENERATION R STUDY

Korevaar TIM ${ }^{1}$, Medici $M^{1}$, de Rijke YB ${ }^{2}$, Visser $W^{3}$, de Muinck Keizer-Schrama SMPF 1 , Jaddoe WVW ${ }^{4}$, Hofman $A^{4}$, Visser WE ${ }^{1}$, Hooijkaas $H^{5}$, Steegers EAP ${ }^{3}$, Tiemeier $H^{4}$, Bongers-Schokking $J^{1}$, Visser $T J^{1}$, Peeters $R P^{1}$

${ }^{1}$ Erasmus Medical Center, Endocrinology, Rotterdam, Netherlands, ${ }^{2}$ Erasmus Medical Center, Clinical Chemistry, Rotterdam, Netherlands, ${ }^{3}$ Erasmus Medical Center, Gynaecology, Rotterdam, Netherlands, ${ }^{4}$ Erasmus Medical Center, Epidemiology, Rotterdam, Netherlands, ${ }^{5}$ Erasmus Medical Center, Immunology, Rotterdam, Netherlands

$16.45-17.00$

OP10 TLR3 SIGNALING PROMOTES METASTASIS OF PAPILLARY THYROID CANCER BY MODULATING CD44 EXPRESSION THROUGH PI3K/AKT PATHWAY

$\underline{L i}^{1,2}$, Gu $R^{3}$, Nie $X^{4}$, Zhao $Q^{1}, \mathrm{Du} Q^{1}$, Guo $H^{1}$, Shi $L^{1}$, Huang $T^{1}$ ${ }^{1}$ Department of Breast and Thyroid Surgery, Union Hospital, Tongji Medical College, Huazhong University of Science and Technology, Wuhan, China, ${ }^{2}$ Department of Thyroid and Neck Tumor, Tianjin Medical University Cancer Institute and Hospital, Tianjin, China, ${ }^{3}$ Department of Cancer Center, Union Hospital, Tongji Medical College, Huazhong University of Science and Technology, Wuhan, China, ${ }^{4}$ Department of Pathology, Union Hospital, Tongji Medical College, Huazhong University of Science and Technology, Wuhan, China 
$17.00-17.15$

OP11 IDENTIFICATION AND FUNCTIONAL STUDIES OF DUOX2 VARIANTS IN A LARGE SERIES OF PATIENTS WITH CONGENITAL HYPOTHYROIDISM

Muzza $M^{1}$, Rabbiosi $S^{2}$, Zamproni $~^{2}$, Persani $L^{1,3}$, Cortinovis $F^{2}$, Vigone $M C^{2}$, Beccaria $L^{4}$, Schoenmakers $N^{5}$, Gallo $F^{6}$, Weber $G^{2}$, Fugazzola $L^{1}$

${ }^{1}$ University of Milan, Department of Clinical Sciences and Community Health, Milan, Italy, ${ }^{2}$ San Raffaele

Scientific Institute, Vita-Salute San Raffaele University, Department of Pediatrics, Milan, Italy, ${ }^{3}$ Istituto Auxologico Italiano, Milan, Italy, ${ }^{4}$ A. Manzoni Hospital, Lecco, Italy, ${ }^{5}$ University of Cambridge, Institute of Metabolic Science, Cambridge, United Kingdom, ${ }^{6}$ Perrino Hospital, Brindisi, Italy

\section{$17.15-17.30$}

OP12 PATTERNS OF THYROID HORMONE RECEPTOR EXPRESSION DURING THE EARLY STAGES OF ZEBRAFISH DEVELOPMENT

Marelli $F^{1}$, Chatterjee $K^{2}$, Peeters $R P^{3}$, Persani $L^{1,4}$

${ }^{1}$ IRCCS Istituto Auxologico Italiano, Sperimental Laboratory of Endocrine and Metabolic Research, Cusano Milanino, Italy, ${ }^{2}$ University of Cambridge, Metabolic Research Laboratory, Cambridge, United Kingdom, ${ }^{3}$ Erasmus Medical Center, Departments of Internal Medicine, Rotterdam, Netherlands, ${ }^{4}$ University of Milan, Department of Medical Science, Milan, Italy

$17.30-17.45$

OP13 MICRORNA 214 IS A POTENTIAL REGULATOR OF THYROID HORMONE LEVELS IN THE POST-MI HEART BY TARGETING THE THYROID HORMONE INACTIVATING ENZYME DEIODINASE TYPE III

Janssen $R^{1}$, Zuidwijk $M^{1}$, Muller $A^{1}$, Oudejans $C^{2}$, Simonides $W^{1}$ ${ }^{1}$ Institute for Cardiovascular Research / VU University Medical Center, Department of Physiology, Amsterdam, Netherlands, ${ }^{2}$ VU University Medical Center, Department of Clinical Chemistry, Amsterdam, Netherlands

\section{$17.45-18.00$}

OP14 CLINICAL AND LABORATORY FEATURES OF IGSF1 DEFICIENCY IN MALES AND FEMALES

Joustra $S^{1,2}$, Schoenmakers $N^{3}$, Oostdijk $W^{2}$, Corssmit EP', Heinen $C A^{4}$, Bonomi $M^{5}$, Radetti $G^{6}$, Persani $L^{5,7}$, Campi $P^{7,8}$, Biermasz $N R^{1}$, Pereira $A M^{1}$, Chatterjee $K^{3}$, Dattani $M T^{9}$, Wit $\mathrm{JM}^{2}$, van Trotsenburg ASP

${ }^{1}$ Leiden University Medical Center, Endocrinology and Metabolism, Leiden, Netherlands, ${ }^{2}$ Leiden University Medical Center, Paediatric Endocrinology, Leiden, Netherlands, ${ }^{3}$ Addenbrooke's Hospital, Institute of Metabolic Science, Cambridge, United Kingdom, ${ }^{4}$ Academic Medical Centre, Paediatric Endocrinology, Amsterdam, Netherlands, ${ }^{5}$ IRCCS Istituto Auxologico Italiano, Endocrine and Metabolic Disorders, Milan, Italy, ${ }^{6}$ Bolzano Hospital, Pediatric Unit, Bolzano, Italy, ${ }^{7}$ Università degli Studi di Milano, Clinical Sciences \& Community Health, Milan, Italy, ${ }^{8}$ Fondazione IRCCS
Ca' Granda, Endocrine Unit, Milan, Italy, ${ }^{9} \mathrm{UCL}$ Institute of Child Health, Developmental Endocrinology Research Group, London, United Kingdom

\section{Grote Zaal/Main Auditorium}

18.00-18.45

\section{Aldo Pinchera Lecture Prize}

Chairpersons: Theo Visser, The Netherlands

Furio Pacini, Italy

Graves' orbitopathy: imperfect treatments for a rare disease Luigi Bartalena, Italy

\section{Grote Zaal/Main Auditorium \\ 19.00-20.30

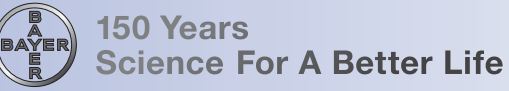

Bayer HealthCare-Sponsored Satellite Symposium

\section{The Road Ahead in Differentiated}

\section{Thyroid Cancer}

Chair: Martin Schlumberger, France

19.00-19.20 Recent progress in our understanding of DTC and the RAI-refractory patient Martin Schlumberger, France

19.20-19.40 What we have learned from the biology and the signaling pathways of DTC - the rationale behind targeted therapies Furio Pacini, Italy

19.40-20.00 Recent progress in the treatment of RAI-refractory DTC Marcia Brose, USA

20.00-20.20 Learning from clinical experience and future direction with tyrosine kinase inhibitors

Johannes Smit, The Netherlands

20.20-20.30 Faculty discussion and questions to the audience

Dinner will be provided to attendees 
Grote Zaal

$08.00-10.00$

Oral Session 3:

Thyroid Cancer Clinical 1 (OP15-OP22)

Chairpersons: Rossella Elisei, Italy

Iris Wakelkamp, The Netherlands

08.00-08.17

OP15 THYROID LUNG METASTASES TREATED WITH PERCUTANEOUS THERMAL ABLATION: RESULTS FROM 25 PATIENTS AND 58 NODULES

Bonichon $F^{1}$, de Baere $T^{2}$, Godbert $Y^{3}$, Leboulleux $S^{4}$, Deschamps $F^{2}$, Buy $X^{5}$, Chougnet $C N^{6}$, Do Cao $C^{7}$, Toubeau $M^{8}$, Giraudet $A-L^{9}$, Palussiere $J^{5}$, Tuthyref network

${ }^{1}$ Institut Bergonie, Nuclear Medicine, Bordeaux Cedex, France, ${ }^{2}$ Institut Gustave Roussy, Interventional Radiology, Villejuif, France, ${ }^{3}$ Institut Bergonie, Nuclear Medicine, Bordeaux cedex, France, ${ }^{4}$ Institut Gustave Roussy, Nuclear Medicine, Villejuif, France, ${ }^{5}$ Institut Bergonie, Interventional Radiology, Bordeaux, France, ${ }^{6}$ Institut Gustave Roussy, Nuclear Medicine and Endocrine Cancer, Villejuif, France, ${ }^{7}$ Hôpital Claude Huriez, CHRU, Service d'Endocrinologie et de Maladies Metaboliques, Lille, France, ${ }^{8}$ Centre Georges-François Leclerc,

Nuclear Medicine, Dijon, France, ${ }^{9}$ Centre Leon Berard,

Nuclear Medicine, Lyon, France

OP16 (to be presented as a poster: Poster session P012 Basic Cancer 2)

OP16 CLINICAL UTILITY OF ${ }^{18}$ F-FLUORODEOXYGLUCOSE

PET/CT CONCURRENT WITH ${ }^{131}$ I THERAPY IN

INTERMEDIATE-TO-HIGH RISK PATIENTS WITH

DIFFERENTIATED THYROID CANCER: DUAL-CENTER

EXPERIENCE WITH 286 PATIENTS

Lee J-W $W^{1}$, Lee S-M ${ }^{2}$, Lee $D-H^{3}, \operatorname{Kim} Y-J^{4}$

${ }^{1}$ Yonsei University College of Medicine, Department of Nuclear Medicine, Seoul, Republic of Korea, ${ }^{2}$ Soonchunhyang University Hospital, Department of Nuclear Medicine,

Cheonan, Republic of Korea, ${ }^{3}$ Wonkwang University School of Medicine and Hospital, Department of Internal Medicine,

Iksan, Republic of Korea, ${ }^{4}$ Soonchunhyang University Hospital, Department of Internal Medicine, Cheonan, Republic of Korea
08.17-08.34

OP17 STRATIFIED GENETIC ANALYSIS ENHANCES THE DETECTION OF MALIGNANT LESIONS IN THYROID NODULES

Zatelli $M C^{1,2}$, Filieri $C^{1}$, Rossi $M^{1}$, Buratto $M^{1}$, Tagliati $F^{1}$, Trasforini $G^{1}$, Lanza $G^{3}$, Rossi $R^{1}$, degli Uberti $E C^{1,2}$

${ }^{1}$ University of Ferrara, Section of Endocrinology, Dept. of Medical Sciences, Ferrara, Italy, ${ }^{2}$ Laboratorio in rete del Tecnopolo 'Tecnologie delle terapie avanzate' (LTTA) of the University of Ferrara, Ferrara, Italy, ${ }^{3}$ University of Ferrara, Section of Sezione di Pathology and Bio-molecular Diagnostics, Dept. of Biomedical Sciences and Advanced Therapies, Ferrara, Italy

08.34-08.51

OP18 AUTOIMMUNE THYROIDITIS IS NOT ASSOCIATED WITH INCREASED RISK OF THYROID CANCER IN A CYTOLOGICAL SERIES OF THYROID NODULES

Belardini $V^{1}$, Castagna $M G^{1}$, Memmo $S^{1}$, Maino $F^{1}, D^{\prime}$ Angeli $F^{1}$, Evangelista $I A^{1}$, Pacini $F^{1}$

${ }^{1}$ Section of Endocrinology, University of Siena, Siena, Italy

08.51-09.08

OP19 RET TRANSLOCATIONS IN PAPILLARY THYROID CARCINOMA DETECTED BY A BREAK-APART INTERPHASE FLUORESCENCE IN SITU HYBRIDIZATION ASSAY

Pedron $S^{1}$, Colato $C^{1}$, Brazzarola $P^{2}$, Chilosi $M^{1}$, Ferdeghini $M^{1}$ ${ }^{1}$ University of Verona, Pathology and Diagnostics, Verona, Italy,

${ }^{2}$ University of Verona, Surgery and Oncology, Verona, Italy

\section{$09.08-09.25$}

OP20 MODIFIED DYNAMIC RISK STRATIFICATION FOR PREDICTING RECURRENCE USING THE RESPONSE TO INITIAL THERAPY IN PATIENTS WITH DIFFERENTIATED THYROID CARCINOMA

Jeon $M J^{1}$, Kim WG ${ }^{1}$, Park $W R^{1}$, Han $J M^{1}$, Kim $T Y^{1}$, Chung $K-W^{2}$, Song $D E^{3}$, Ryu J-S ${ }^{4}$, Hong $S J^{2}$, Shong $Y K^{1}$, Kim WB ${ }^{1}$

${ }^{1}$ Asan Medical Center, University of Ulsan College of Medicine, Internal Medicine, Seoul, Republic of Korea, ${ }^{2}$ Asan Medical Center, University of Ulsan College of Medicine, Surgery, Seoul, Republic of Korea, ${ }^{3}$ Asan Medical Center, University of Ulsan College of Medicine, Pathology, Seoul, Republic of Korea,

${ }^{4}$ Asan Medical Center, University of Ulsan College of Medicine, Nuclear Medicine, Seoul, Republic of Korea 


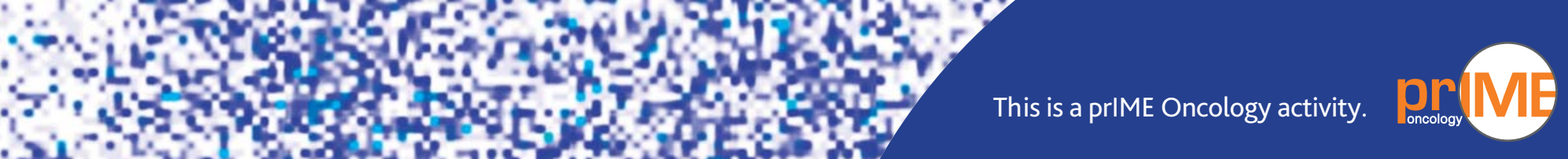

A Satellite Symposium Held in Conjunction With the $37^{\text {th }}$

Annual Meeting of the European Thyroid Association

\section{HOW I TREAT ADVANCED DIFFERENTIATED THYROID CANCER IN 2013}

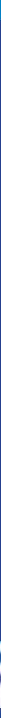

FACULTY Rossella Elisei, MD (Chair) Barbara Jarzab, MD University of Pisa

Pisa, Italy
MSC Memorial Cancer Center

Gliwice, Poland
Furio Pacini, MD

Azienda Ospedaliera Universitaria Senese

Siena, Italy

\section{AGENDA}

Welcome and introduction Rossella Elisei, MD

13.00 How I treat newly-diagnosed advanced differentiated thyroid cancer (DTC) Furio Pacini, MD

13.15 Challenge the expert

13.20 How I treat radioactive iodine (RAI)refractory DTC Rossella Elisei, MD

13.35 Challenge the expert

13.40 How I manage adverse events associated with targeted therapy Barbara Jarzab, MD

13.55 Challenge the expert

14.00 Concluding remarks Rossella Elisei, MD

\section{TARGET AUDIENCE}

This educational activity is specifically designed for endocrinologists, oncologists, and other healthcare professionals interested and/or involved in the treatment of patients with advanced differentiated thyroid cancer.

\section{EDUCATIONAL OBJECTIVES}

After successful completion of this educational activity, participants should be able to:

- Describe the prognosis and current management of advanced DTC

- Identify the role of multidisciplinary treatment approach in the management of DTC

- Define RAI-refractory DTC and evaluate treatment strategies, including recent advances

- Discuss importance of patient selection for treatment with tyrosine kinase inhibitors

- Evaluate importance of early recognition and management of adverse events

Eisai Support for this educational activity is provided by Eisai Inc. 
09.25-09.42

OP21 HIGH-RISK PATIENTS WITH DIFFERENTIATED

THYROID CANCER T4 PRIMARY TUMORS ACHIEVE

REMNANT ABLATION EQUALLY WELL USING

RECOMBINANT HUMAN TSH OR THYROID HORMONE WITHDRAWAL

Bartenstein $P^{1}$, Caballero Calabuig $E^{2}$, Maini $C L^{3}$, Mazzarotto $R^{4}$, Muros de Fuentes $M A^{5}$, Petrich $T^{6}$, Rodrigues $F^{3} C^{7}$,

Vallejo Casas $J A^{8}$, Vianello $F^{9}$, Basso $M^{9}$, Gomez Balaguer $M^{2}$, Haug $A^{1}$, Monari $F^{4}$, Sanchez-Vano $R^{2}$, Sciuto $R^{3}$, Magner ${ }^{10}$ ${ }^{1}$ Klinikum der Universitaet Muenchen, Muenchen, Germany, ${ }^{2}$ Hospital Universitario Dr. Peset Valencia, Valencia, Spain, ${ }^{3}$ Istituto Nazionale Tumori Regina Elena IRCCS, Roma, Italy, ${ }^{4}$ Policlinico S. Orsola Malphighi, Bologna, Italy,

${ }^{5}$ Hospital Universitario Virgen de las Nieves, Granada, Spain, ${ }^{6}$ Medizinische Hochschule Hannover, Hannover, Germany,

${ }^{7}$ Instituto Portugues de Oncologia de Coimbra Francisco Gentil, Coimbra, Portugal, ${ }^{8}$ Hospital Universitario Reina Sofia de Cordoba, Andalucia, Spain, '9 Istituto Oncologico Veneto-IRCCS, Padova, Italy, ${ }^{10}$ Genzyme, a Sanofi Company, Cambridge, United States

09.42-10.00

OP22 IMPACT OF CONCURRENT CHRONIC LYMPHOCYTIC THYROIDITIS (CTL) ON PAPILLARY THYROID CANCER (PTC) OUTCOME: THE POTENTIAL KEY ROLE OF FOXP3+ T LYMPHOCYTES

Pilli $T^{1}$, Toti $P^{2}$, Castagna $M G^{1}$, Occhini $R^{2}$, Caselli $M^{1}$, Barbagli $L^{2}$, Memmo $S^{1}$, Maino $F^{1}$, Pacini $F^{1}$

${ }^{1}$ University of Siena, Section of Endocrinology, Department of Medical, Surgical and Neurological Sciences, Siena, Italy,

${ }^{2}$ University of Siena, Section of Anatomy\&Pathology, Department of Anatomy \& Pathology and Medical Biotechnology, Siena, Italy

\section{Aalmarkt Zaal}

\subsection{0-10.00}

\section{Oral Session 4:}

Thyroid Hormone Action (OP23-OP30)

Chairpersons: Jens Mittag, Sweden

Edward Visser, The Netherlands

08.00-08.15

OP23 EFFECT OF 3,5-DIIODO-L-THYRONINE ON HIGH-FAT DIET-INDUCED VISCERAL ADIPOSITY IN THE RAT

Senese $R^{1}$, de Lange $P^{1}$, Leanza $C^{1}$, Ziello $A^{1}$, Lasala $P^{1}$, De Matteis $R^{2}$, Lattanzi $D^{3}$, Lanni $A^{1}$

'Dipartimento di Scienze e Tecnologie Ambientali, Biologiche e Farmaceutiche, Seconda Università degli Studi di Napoli, Caserta, Italy, ${ }^{2}$ Dip. Scienze Biomolecolari-Sezione di Scienze
Motorie e della Salute, Università di Urbino 'Carlo Bo', Urbino, Italy, ${ }^{3}$ Dip. Scienze della Terra, della Vita e dell'Ambiente, Università di Urbino 'Carlo Bo', Urbino, Italy

$08.15-08.30$

OP24 METABOLIC EFFECTS OF 3,5-DIIODO-L-THYRONINE: FOCUS ON BROWN ADIPOSE TISSUE

Lombardi $A^{1}$, De Matteis $R^{2}$, Busiello $R A^{3}$, Cioffi $F^{3}$, Senese $R^{4}$, Goglia $F^{5}$

${ }^{1}$ Università di Napoli Federico II, Biological Science, Napoli, Italy, ${ }^{2}$ Università degli Studi di Milano di Urbino, Dipartimento di Scienze Biomolecolari, Sezione di Scienze Motorie e della Salute, Urbino, Italy, ${ }^{3}$ Università degli Studi del Sannio, Dipartimento di Scienze per la Biologia, la Geologia e L'Ambiente, Benevento, Italy, ${ }^{4}$ Seconda Università di Napoli, Napoli, Italy, ${ }^{5}$ Università degli Studi del Sannio, Benevento, Italy

08.30-08.45

OP25 BLOCKING $T_{3}$ SIGNALLING ENHANCES AXON REGENERATION AND OPTIC TECTUM REINNERVATION FOLLOWING OPTIC NERVE INJURY

Bhumika $S^{1}$, Moons $L^{2}$, Darras $V^{1}$

${ }^{1} \mathrm{KU}$ Leuven, Laboratory of Comparative Endocrinology, Leuven, Belgium, ${ }^{2} \mathrm{KU}$ Leuven, Laboratory of Neural Circuit Development and Regeneration, Leuven, Belgium

08.45-09.00

OP26 PRO-LEARNING AND ANTI-AMNESTIC EFFECTS OF 3-IODOTHYRONAMINE AND 3-IODOTHYROACETIC ACID IN MOUSE

Musilli $C^{1}$, Manni ME ${ }^{1}$, De Siena $G^{1}$, Logli $A^{1}$, Saba $A^{2}$, Landucci E', Zucchi $R^{2}$, Raimondi $L^{1}$

${ }^{1}$ University of Florence, Firenze, Italy, ${ }^{2}$ University of Pisa, Pisa, Italy

09.00-09.15

OP27 EVIDENCE FOR A ROLE OF UNLIGANDED THYROID HORMONE RECEPTORS ON CEREBROCORTICAL NEURONS IN PRIMARY CULTURE

Gil-lbañez $P^{1}$, Morte $B^{1}$, Bernal $J^{1}$

${ }^{1}$ Instituto de Investigaciones Biomédicas (CSIC-UAM) CIBERER, Madrid, Spain

09.15-09.30

OP28 EFFECTS OF 3,5-DIIODO-L-THYRONINE ON

SKELETAL MUSCLE METABOLISM: INTERRELATION BETWEEN INSULIN SENSITIVITY AND MITOCHONDRIAL PHENOTYPE

Cioffi $F^{1}$, Glinni $D^{1}$, Coppola $M^{1}$, Silvestri $E^{1}$, Moreno $M^{1}$, Goglia $F^{1}$ ${ }^{1}$ University of Sannio, Dept. of Sciences and Technologies, Benevento, Italy 
$09.30-09.45$

OP29 WEIGHT LOSS WITH PRESERVED GLUCOSE HOMEOSTASIS DURING CHRONIC TREATMENT OF OBESE MICE WITH 3-IODOTHYRONAMINE (T1AM): ROLE OF THE SIRTUIN FAMILY

Chiellini $G^{1,2}$, Assadi-Porter $\mathrm{FM}^{2}$, Reiland $\mathrm{H}^{2}$, Carnicelli $\mathrm{V}^{1}$, Butz $D^{2}$, Tonelli $M^{2}$, Selen $E S^{2}$, Lorenzini $L^{1}$, Ghelardoni $S^{1}$, Scanlan $T S^{3}$, Zucchi $R^{1}$

${ }^{1}$ University of Pisa, Pisa, Italy, ${ }^{2}$ University of Wisconsin, Madison, United States, ${ }^{3}$ Oregon Health and Science University, Portland, United States

\subsection{5-10.00}

OP30 N-ACETYLATION OF 3-IODOTHYRONAMINE REVERSES ITS EFFECTS ON THERMOREGULATION AND CARDIOVASCULAR FUNCTION

$\underline{\text { Hoefig CS }}^{1}$, Warner $A^{1}$, Vennström $B^{1}$, Scanlan TS ${ }^{2}$, Mittag $J^{1}$

${ }^{1}$ Karolinska Institutet, Department of Cell \& Molecular Biology, Stockholm, Sweden, ${ }^{2}$ Oregon Health and Science

University, Department of Physiology and Pharmacology,

Portland, United States

10.00-10.30 Coffee break

\section{Aalmarkt Zaal}

\subsection{0-12.00}

\section{Symposium 3 (Basic): Thyroid Hormone and}

\section{Stemness}

Chairpersons: Clara Alvarez, Spain

Robin Peeters, The Netherlands

\begin{tabular}{|c|c|}
\hline $10.30-11.00$ & $\begin{array}{l}\text { Intestinal stem cells } \\
\text { Michelina Plateroti, France }\end{array}$ \\
\hline $11.00-11.30$ & $\begin{array}{l}\text { Neuronal stem cells } \\
\text { Barbara Demeneix, France }\end{array}$ \\
\hline $30-12.00$ & $\begin{array}{l}\text { Skin stem cells } \\
\text { Ana Aranda, Spain }\end{array}$ \\
\hline
\end{tabular}

Grote Zaal/Main Auditorium

10.30-12.00

\section{Symposium 4 (Clinical): Thyroid Investigations in} at Risk Populations

Chairpersons: Simon Pearce, UK

Noortje van der Kleij-Corssmit, The Netherlands

10.30-11.00 Autoimmune diseases

Wilmar Wiersinga, The Netherlands

11.00-11.30 Nodular disease and differentiated thyroid carcinoma

Ralf Paschke, Germany

11.30-12.00 Cardiovascular disease

Salman Razvi, UK
Poster Area

12.00-13.00

Lunch and Poster Discussion 2 (Posters 95-183) (see pages 48 to 56)

Poster Session 11: Thyroid Autoimmunity Clinical

Chairperson: Stefano Mariotti, Italy

Poster Session 12: Thyroid Cancer Basic 2

Chairperson: Dagmar Führer, Germany

Poster Session 13: Thyroid Cancer Diagnostics 2

Chairperson: Ulla Feldt-Rasmussen, Denmark

Poster Session 14: Thyroid Nodules and Goitre 1

Chairperson: Laszlo Hegedüs, Denmark

Poster Session 15: Thyroid Cancer Therapeutics 2

Chairperson: Alicja Hubalewska-Dydejczyk, Poland

Poster Session 16: Case Reports 2

Chairperson: Bojan Lozanov, Bulgaria

Poster Session 17: Clinical Thyroidology 2

Chairperson: Joao de Castro, Portugal

Poster Session 18: Environmental Influences on Thyroid

Function

Chairperson: Leonidas Duntas, Greece

Poster Session 19: Hyperthyroidism 2

Chairperson: Chantal Daumerie, Belgium

Poster Session 20: Hypothyroidism

Chairperson: Marek Niedziela, Poland

Grote Zaal/Main Auditorium

$13.00-14.00$

Eisai

prIME Oncology Satellite Symposium supported

by Eisai Inc.

\section{How I Treat Advanced \\ Differentiated Thyroid Cancer (DTC) in 2013}

Welcome and introduction

Rossella Elisei, Italy

13.00 How I treat newly-diagnosed advanced DTC Furio Pacini, Italy

13.15 Challenge the expert

13.20 How I treat RAI-refractory DTC Rossella Elisei, Italy

13.35 Challenge the expert

13.40 How I manage adverse events associated with targeted therapy Barbara Jarzab, Poland

13.55 Challenge the expert

14.00 Concluding remarks Rossella Elisei, Italy

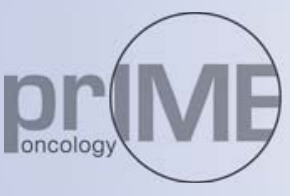


Grote Zaal/Main Auditorium

14.00-14.45

\section{„MerckSerono}

I Living science, transforming lives

\section{Merck Serono Prize Lecture}

Chairpersons: Theo Visser, The Netherlands Luigi Bartalena, Italy

Building a thyroid gland from stem cells: a new era in endocrinology

Sabine Costagliola, Belgium

$14.45-15.00$

Coffee break
Grote Zaal/Main Auditorium

$15.00-17.00$

Oral Session 5:

Clinical Thyroidology 1 (OP31-OP38)

Chairpersons: George J. Kahaly, Germany Eric Fliers, The Netherlands

$15.00-15.15$

OP31 ASSOCIATION OF HYPER- AND HYPOTHYROIDISM WITH ALL CAUSE MORTALITY IN A POPULATION-BASED STUDY OF 260,790 DANES

Laulund $A S^{1}$, Nybo $M^{2}$, Brix $T H^{1}$, Abrahamsen $B^{3,4}$, Jørgensen $H L^{5}$ Hegedüs $L^{1}$

${ }^{1}$ University of Southern Denmark, Department of Endocrinology, Odense, Denmark, ${ }^{2}$ Odense University Hospital, Department of Clinical Biochemistry and Pharmacology, Odense, Denmark, ${ }^{3}$ University of Southern Denmark, Institute of Clinical Research, Odense, Denmark, ${ }^{4}$ Gentofte Hospital, Department of Medicine, Copenhagen, Denmark, ${ }^{5}$ Bispebjerg Hospital, Department of Clinical Biochemistry, Copenhagen, Denmark

$15.15-15.30$

OP32 PSYCHIATRIC MORBIDITY IS INCREASED BOTH BEFORE AND AFTER THE DIAGNOSIS OF HYPERTHYROIDISM: A NATIONWIDE REGISTER-BASED STUDY

Brandt $F^{1}$, Thvilum $M^{1}$, Almind $D^{2}$, Christensen $K^{2}$, Green $A^{3}$, Hegedüs $L^{1}$, Brix $T H^{1}$

'Odense University Hospital, Department of Endocrinology and Metabolism, Odense C, Denmark, ${ }^{2}$ University of Southern Denmark, The Danish Aging Research Center and The Danish Twin Registry, Odense C, Denmark, ${ }^{3}$ University of Southern Denmark, Odense Patient Data Exploratory Network, Odense C, Denmark

$15.30-15.45$

OP33 HYPERTHYROIDISM INCREASES BROWN FAT METABOLISM IN HUMANS

Schalin-Jäntti $C^{1}$, Lahesmaa $M^{2}$, Orava $J^{2}$, Soinio $M^{3}$, Hannukainen $J C^{2}$, Noponen $T^{2}$, Kirjavainen $A^{2}$, Virtanen $K A^{2}$, Nuutila $P^{2,3}$

${ }^{1}$ University of Helsinki and Helsinki University Hospital, Division of Endocrinology, Department of Medicine, Helsinki, Finland, ${ }^{2}$ Turku PET Centre, Turku, Finland, ${ }^{3}$ Department of Medicine, University of Turku, Turku, Finland

$15.45-16.00$

OP34 STUDIES ON AGRANULOCYTOSIS: ANALYSES

OF PHYSICIANS' REPORTS OF THE 754 CASES OF

ANTITHYROID DRUG-INDUCED AGRANULOCYTOSIS DURING 30 YEARS IN JAPAN

Nakamura $H^{1}$, Miyauchi $A^{1}$, Miyawaki $N^{2}$, Imagaw $J^{2}$

${ }^{1}$ Kuma Hospital, Kobe, Japan, ${ }^{2}$ Chugai Pharmaceutical Co., Ltd, Tokyo, Japan

Eur Thyroid J Vol. 2, Suppl. 1, 2013 
$16.00-16.15$

OP35 THYROID FUNCTION MONITORING AND TSH LEVELS

IN PREGNANT INDIVIDUALS ON LEVOTHYROXINE FOR

PRIMARY HYPOTHYROIDISM IN THE UK

Taylor $P N^{1}$, Minassian $C^{2}$, lqbal $A^{3}$, Rehman $A^{4}$, Thomas $S L^{2}$,

Okosieme $\mathrm{O}^{1}$, Lazarus $\mathrm{J}^{1}$, Dayan $\mathrm{CM}^{1}$

${ }^{1}$ Cardiff University, Institute of Molecular and Experimental

Medicine, Cardiff, United Kingdom, ${ }^{2}$ London School of

Hygiene and Tropical Medicine, Faculty of Epidemiology and

Population Health, London, United Kingdom, ${ }^{3}$ University of

Bristol, Henry Wellcome Laboratories for Integrative

Neurosciences and Endocrinology, Bristol, United Kingdom,

${ }^{4}$ Akron General Medical Center, Department of Internal

Medicine, Akron, Ohio, United States

$16.15-16.30$

OP36 THE TEMPORAL ASSOCIATION BETWEEN HYPOTHYROIDISM AND PSYCHIATRIC MORBIDITY. A NATIONWIDE REGISTER-BASED STUDY

Thvilum $M^{1}$, Brandt $F^{1}$, Almind $D^{2}$, Christensen $K^{2}$, Brix $T H^{1}$, Hegedüs $L^{1}$

'Odense University Hospital, Department of Endocrinology,

Odense C, Denmark, ²University of Southern Denmark, Danish

Twin Registry, Odense C, Denmark

$16.30-16.45$

OP37 METFORMIN INHIBITS GOITROGENOUS EFFECTS OF

TYPE 2 DIABETES

Ittermann $T^{1}$, Markus MR ${ }^{1}$, Schipf $S^{1}$, Derwahl $M^{2}$, Meisinger $C^{3}$, Völzke $H^{1}$

${ }^{1}$ University Medicine Greifswald, Greifswald, Germany,

${ }^{2}$ St. Hedwig Hospital, Berlin, Germany, ${ }^{3}$ German Research

Center for Environmental Health, München, Germany

16.45.17.00

OP38 RADIOFREQUENCY ABLATION USING MOVING SHOT TECHNIQUE IS A REPRODUCIBLE, EFFECTIVE TECHNIQUE FOR TREATING BENIGN THYROID NODULES. PRELIMINARY RESULTS OF AN INTERNATIONAL RANDOMIZED CONTROLLED TRIAL

Deandrea $M^{1}$, Kee Shong,$Y^{2}$, Sung $\mathrm{JY}^{3}$, Kim $\mathrm{KS}^{3}$, Mormile $A^{1}$, Gamarra $E^{1}$, Garino $F^{1}$, Ragazzoni $F^{1}$, Garberoglio $R^{4}$, Limone $P P^{1}$, Baek JH ${ }^{5}$

${ }^{1}$ Mauriziano Hospital 'Umberto I' of Turin, Department of Endocrinology and Metabolism, Turin, Italy, ${ }^{2}$ University of Ulsan College of Medicine, Asan Medical Center, Department of Endocrinology and Metabolism, Seoul, Republic of Korea, ${ }^{3}$ Daerim St. Mary's Hospital, Department of Radiology, Thyroid Center, Seoul, Republic of Korea, ${ }^{4}$ Mauriziano Hospital 'Umberto I' of Turin, Mauriziano Scientific Foundation, Turin, Italy, ${ }^{5}$ University of Ulsan College of Medicine, Asan Medical Center, Department of Radiology and Research Institute of Radiology, Seoul, Republic of Korea
Aalmarkt Zaal

$15.00-17.00$

\section{Oral Session 6:}

Thyroid Basic/Translational (OP39-OP46)

Chairpersons: Georg Brabant, Germany Sabine Costagliola, Belgium

$15.00-15.15$

OP39 SMALL MOLECULE SCREENING IDENTIFIES

SIGNALLING PATHWAYS REGULATING THYROID MORPHOGENESIS IN ZEBRAFISH EMBRYOS

Opitz $R^{1}$, Vandernoot $I^{1}$, Haerlingen $B^{1}$, Trubiroha $A^{1}$, Costagliola $S^{1}$

${ }^{1}$ IRIBHM, Université Libre de Bruxelles, Brussels, Belgium

$15.15-15.30$

OP40 IDENTIFICATION OF NIS AND DUOX2 AS DIRECT FOXE1 TARGET GENES IN THYROID CELLS

Fernández $L P^{1}$, López-Márquez $A^{1}$, Martínez $A M^{1,2}$, Gómez-López $G^{2}$, Santisteban $P^{1}$

${ }^{1}$ Instituto de Investigaciones Biomédicas (CSIC-UAM), Madrid, Spain, ${ }^{2}$ Centro Nacional de Investigaciones Oncológicas (CNIO), Madrid, Spain

$15.30-15.45$

OP41 NOVEL CARBOXY-TERMINAL MUTATIONS IN DEHAL1 AND IODOTYROSINE DEIODINASE DEFICIENCY Iglesias $A^{1}$, García $L^{2}$, Wemeau $\mathrm{L}^{3}$, Vincens $M^{4}$, Leger $A^{5}$, Brunet $E^{6}$, Joubert $M^{7}$, Torrabías $M^{8}$, Corripio $R^{9}$, Visser $T J^{10}$, Cocho $\mathrm{J}^{2}$, Moreno $\mathrm{JC}^{1}$

${ }^{1}$ La Paz University Hospital, Institute for Medical and Molecular Genetics (INGEMM), Madrid, Spain, ${ }^{2}$ University Hospital, Metabolopathies Laboratory, Santiago de Compostela, Spain, ${ }^{3}$ Claude-Huriez Hospital, Endocrinology Service, Lille, France, ${ }^{4}$ Cochin Hospital, Endocrinology Service, Paris, France, ${ }^{5}$ La Pitié Hospital, Nuclear Medicine Service, Paris, France, ${ }^{6}$ Autonomous University of Madrid, Faculty of Sciences, Madrid, Spain, ${ }^{7}$ Caen Hospital, Diabetes-Endocrinology Service, Caen, France, ${ }^{8}$ Vic Hospital, Endocrinology Service, Barcelona, Spain, ${ }^{9}$ Parc Taulí Hospital of Sabadell, Sabadell, Spain,

${ }^{10}$ Erasmus Medical Center, Rotterdam, Netherlands

$15.45-16.00$

OP42 FEEDBACK REGULATION OF T3 SIGNALING PATHWAY THROUGH MICRORNAS

Boguslawska J1 , Piekielko-Witkowska $A^{1}$, Kedzierska $H^{1}$, Poplawski $P^{1}$, Nauman $A^{1}$

${ }^{1}$ The Centre of Postgraduate Medical Education, Department of Biochemistry and Molecular Biology, Warsaw, Poland 
$16.00-16.15$

OP43 FUNCTIONAL REGENERATION OF RECURRENT LARYNGEAL NERVE INJURY AFTER THYROIDECTOMY USING AN ASYMMETRICALLY POROUS NERVE GUIDE CONDUIT

Lim J-Y' ${ }^{1}$, Choi J-S , Lee JH ${ }^{2}, \operatorname{Kim} Y-M^{1}$

${ }^{1}$ Inha University School of Medicine, Department of Otorhinolaryngology-Head and Neck Surgery, Incheon, Republic of Korea, ${ }^{2}$ Hannam University, Department of Advanced Materials, Daejeon, Republic of Korea

$16.15-16.30$

OP44 MODULATION OF MCT8 MRNA IN THE THYROID DURING THE WOLFF-CHAIKOFF EFFECT: NEGATIVE REGULATION BY TSH

Lima de Souza $E C^{1}$, Cadoso Penha $R C^{1}$, Fortunato $R S^{1}$, Vaisman $M^{2}$, Freitas Ferreira $A C^{1}$, Carvalho DP ${ }^{1}$

${ }^{1}$ Federal University of Rio de Janeiro, Institute of Biophysics Carlos Chagas Filho, Rio de Janeiro, Brazil, ${ }^{2}$ Universitary Hospital Clementino Fraga Filho, Department of Endocrinology, Rio de Janeiro, Brazil

\section{$16.30-16.45$}

\section{OP45 CORRELATION OF THE EXPRESSION AND} LOCALIZATION OF THYROID HORMONE TRANSPORTERS WITH THYROGLOBULIN-PROCESSING CATHEPSINS IN MOUSE THYROID EPITHELIAL CELLS

Mc Innes J', Weber J', Rehders $M^{1}$, Saftig $P^{2}$, Peters $C^{3}$, Reinheckel $T^{3}$, Schweizer $U^{4}$, Heuer $H^{5}$, Wirth $E K^{6}$, Brix $K^{1}$ Jacobs University Bremen, School of Engineering and Science, Bremen, Germany, ${ }^{2}$ Christian-Albrechts Universität zu Kiel, Institute of Biochemistry, Kiel, Germany,

${ }^{3}$ Albert-Ludwigs-Universität Freiburg, Institut für Molekulare Medizin und Zellforschung, Freiburg, Germany, ${ }^{4}$ Rheinische Friedrich-Wilhelms-Universität Bonn, Institut für Biochemie und Molekularbiologie, Bonn, Germany, ${ }^{5}$ Leibniz Institute for Age Research / Fritz Lipmann Institute (FLI), Jena, Germany, ${ }^{6}$ Charité - Universitätsmedizin Berlin, Institut für Experimentelle Endokrinologie, Berlin, Germany

\section{$16.45-17.00$}

\section{OP46 TRAIL INCREASES SIGNIFICANTLY IN} HYPERTHYROID PATIENTS

Bernardi $S^{1}$, Bossi $F^{2}$, Furlanis $G^{2}$, Bramante $A^{2}$, Secchiero $P^{3}$, Zauli $G^{4}$, Carretta $R^{2}$, Fabris $B^{2}$

${ }^{1}$ Ospedale di Cattinara, Medicina Clinica, Trieste, Italy, ${ }^{2}$ University of Trieste, Dipartimento di Scienze Mediche Chirurgiche e della Salute, Trieste, Italy, ${ }^{3}$ University of Ferrara, Dipartimento di Morfologia ed Embriologia, Trieste, Italy, ${ }^{4}$ IRCCS Burlo Garofolo, Trieste, Italy
17.00-17.45

Meet the Expert 5-8

Waalse Kerk

$17.00-17.45$

MTE 5 (Basic)

Central regulation of peripheral thyroid hormone action

Eric Fliers, The Netherlands

\section{Kleine Foyer}

17.00-17.45

MTE 6 (Basic)

Thyroid hormone transporters

Heike Heuer, Germany

Aalmarkt Zaal

$17.00-17.45$

\section{MTE 7 (Clinical)}

ETA guidelines for cervical ultrasound scan and ultrasound - guided techniques in the postoperative management of patients with thyroid cancer Laurence Leenhardt, France

\section{Grote Zaal/Main Auditorium}

17.00-17.45

MTE 8 (Translational)

Selenium and thyroid function Lutz Schomburg, Germany

\subsection{Departure for Excursion} (Boat trip and Scheltema Complex)

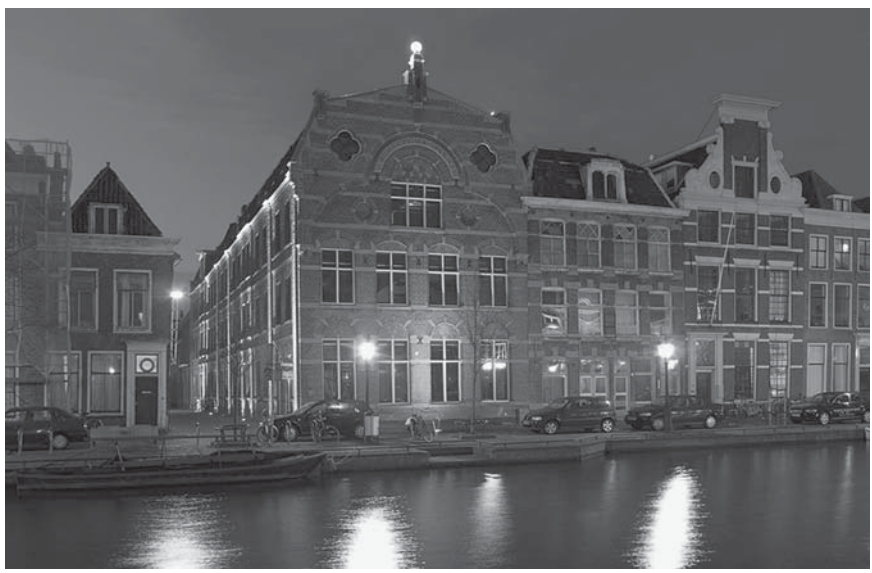

Photo: Courtesy of Scheltema Leiden 


\section{Tuesday, 10th September 2013}

Grote Zaal/Main Auditorium

08.00-10.00

Oral Session 7:

Thyroid Autoimmunity (OP47-OP54)

Chairpersons: Tomasz Bednarczuk, Poland

Hemmo Drexhage, The Netherlands

08.00-08.15

OP47 A GENOME WIDE META-ANALYSIS IN 27,300

SUBJECTS IDENTIFIES NOVEL LOCI ASSOCIATED WITH THYROID PEROXIDASE ANTIBODIES AND CLINICAL THYROID DISEASE

Medici $M^{1}$, Porcu $E^{2}$, Pistis $G^{3}$, Teumer $A^{4}$, Brown $S^{5}$, Jensen $R^{6}$, Rawal $R^{7}$, Roef $G^{8}$, Vermeulen $S^{9}$, Lahti $J^{10}$, Simmonds $M^{11}$, Husemoen $L L^{12}$, Freathy $R^{13}$, Shields $B^{14}$, Pietzner $D^{15}$, Taes $Y^{8}$, Psaty $B^{16}$, Hofman $A^{1}$, Wallaschofski $H^{4}$, Gough $S^{11}$, Meyer zu Schwabedissen $H^{17}$, Frayling $T^{18}$, Kaufman J-M ${ }^{8}$, Linneberg $A^{12}$, Räikkönen $K^{10}$, Rivadeneira $F^{1}$, Uitterlinden $A^{1}$, Walsh $J^{19}$, Meisinger $C^{20}$, den Heijer $M^{21}$, Völzke $H^{4}$, Wilson $S^{22}$, Visser $T^{1}$, Cappola $A^{23}$, Sanna $S^{2}$, Toniolo $D^{3}$, Naitza $S^{2}$, Peeters $R P^{1}$

${ }^{1}$ Erasmus Medical Center, Rotterdam, Netherlands, ${ }^{2}$ Instituto di Ricerca Genetica e Biomedica (IRGB), Consiglio Nazionale delle Ricerche, c/o Cittadella Universitaria di Monserrato, Monserrato, Italy, ${ }^{3}$ Division of Genetics and Cell Biology, San Raffaele Scientific Institute, Milan, Italy, ${ }^{4}$ University Medicine Greifswald, Greifswald, Germany, ${ }^{5}$ Department of Endocrinology and Diabetes, Sir Charles Gairdner Hospital, Nedlands, Western Australia, Australia, ${ }^{6}$ Cardiovascular Health Research Unit, Department of Medicine, University of Washington, Seattle, United States, ${ }^{7}$ Institute for Genetic Epidemiology, Helmholtz Zentrum Munich, Munich/Neuherberg, Germany,

${ }^{8}$ Ghent University Hospital, Ghent, Belgium, ${ }^{9}$ Department of Epidemiology, Biostatistics \& HTA, Radboud University Nijmegen Medical Centre, Nijmegen, Netherlands, ${ }^{10}$ Institute of Behavioural Sciences, University of Helsinki, Helsinki, Finland, ${ }^{11}$ Oxford Centre for Diabetes, Endocrinology and Metabolism, University of Oxford, Churchill Hospital, Headington, Oxford, United Kingdom, ${ }^{12}$ Research Centre for Prevention and Health, Glostrup University Hospital, the Capital Region of Denmark, Glostrup, Denmark, ${ }^{13}$ Genetics of Complex Traits, Peninsula College of Medicine and Dentistry, University of Exeter, Exeter, United Kingdom, ${ }^{14}$ Peninsula NIHR Clinical Research Facility, Peninsula College of Medicine and Dentistry, University of Exeter, Exeter, United Kingdom, ${ }^{15}$ Institute of Medical Epidemiology, Biostatistics, and Informatics, Martin-LutherUniversity, Halle-Wittenberg, Germany, ${ }^{16}$ University of Washington, Seattle, United States, ${ }^{17}$ Department of General
Pharmacology, University Medicine Greifswald, Greifswald, Germany, ${ }^{18}$ University of Exeter, Exeter, United Kingdom, ${ }^{19}$ Sir Charles Gairdner Hospital, Nedlands, Western Australia, Australia, ${ }^{20}$ Institute of Epidemiology II, Helmholtz Zentrum Munich, Munich, Germany, ${ }^{21}$ Department of Internal Medicine, VU Medical Center, Amsterdam, Netherlands, ${ }^{22}$ Department of Twin Research and Genetic Epidemiology, King's College London, London, United Kingdom, ${ }^{23}$ Perelman School of Medicine at the University of Pennsylvania, Philadelphia, United States

08.15-08.30

OP48 CHANGES IN SERUM ADHESION MOLECULES, CHEMOKINES, CYTOKINES AND TISSUE REMODELLING FACTORS IN EUTHYROID WOMEN WITHOUT THYROID ANTIBODIES WHO ARE AT RISK FOR AUTOIMMUNE THYROID DISEASE. A HYPOTHESIS ON THE EARLY PHASES OF THE ENDOCRINE AUTOIMMUNE REACTION

Effraimidis $G^{1}$, Beumer $W^{2}$, Drexhage $R C^{2}$, Wiersinga $W M^{1}$, Drexhage $H A^{2}$

${ }^{1}$ Academical Medical Centre, University of Amsterdam, Endocrinology and Metabolism, Amsterdam, Netherlands, ${ }^{2}$ Erasmus Medical Center, Erasmus University, Department of Immunology, Rotterdam, Netherlands

\subsection{0-08.45}

OP49 CELIAC DISEASE IS HIGHLY PREVALENT IN PATIENTS WITH THYROID-ASSOCIATED ORBITOPATHY

Kahaly GJ', Schuppan $D^{1}$, Ponto $K^{2}$, Diana $T^{1}$, Matheis $N^{1}$

${ }^{1}$ Gutenberg University Medical Center, Department of Medicine I, Mainz, Germany, ${ }^{2}$ Gutenberg University Medical Center, Department of Ophthalmology, Mainz, Germany

08.45-09.00

OP50 SELENIUM SUPPLEMENTATION IN PREGNANT WOMEN WITH CHRONIC AUTOIMMUNE THYROIDITIS: EFFECTS ON SELENIUM, SERUM CONCENTRATION AND AUTOIMMUNE PARAMETERS

Duntas $L H^{1}$, Boutsiadis $A^{1}$, Mantzou $E^{1}$

${ }^{1}$ Endocrine Unit, Evgenidion Hospital, University of Athens, Athens, Greece 
$09.00-09.15$

OP51 THYROID STIMULATING ANTIBODIES IN

GRAVES' DISEASE ARISING FROM PATHOGEN-SPECIFIC

PRECURSORS: THE CONNECTION WITH YERSINIA

\section{ENTEROCOLITICA}

Hargreaves $C^{1}$, Grasso $M^{2}$, Hampe $\mathrm{CS}^{3}$, Stenkova $A^{4}$, Atkinson $S^{2}$, Joshua GW ${ }^{5}$, Wren $B^{5}$, Buckle AM ${ }^{6}$, Dunn-Walters $D^{7}$, Banga JP'

${ }^{1}$ King's College London School of Medicine, Diabetes and Endocrinology, London, United Kingdom, ${ }^{2}$ University of Nottingham, School of Molecular Medical Sciences, Nottingham, United Kingdom, ${ }^{3}$ University of Nottingham, Medicine, Seattle, United States, ${ }^{4}$ Pacific Institute of Bioorganic Chemistry, FEB RAS, Vladisvostok, Russian Federation, ${ }^{5}$ London School of Hygiene and Tropical Medicine, Pathogen Molecular Biology, London, United Kingdom, ${ }^{6}$ Monash University, Biochemistry and Molecular Biology, Clayton, Australia, ${ }^{7}$ King's College London School of Medicine, Immunobiology, London, United Kingdom

\section{$09.15-09.30$}

OP52 DOWNREGULATION OF PPARY EXPRESSION BY TH1

CYTOKINES AND RELATIONSHIP WITH CAVEOLIN-1: A CLUE TO THE PATHOGENESIS OF HASHIMOTO'S THYROIDITIS

Wérion $A^{7}$, Van Regermorter $V^{1}$, Marique $L^{1}$, Craps $J^{\prime}$, Joris $V^{1}$, Senou $M^{1}$, Brichard $S^{2}$, Daumerie $C^{3}$, Mourad $M^{4}$, Lengelé $B^{7}$, Gérard $A-C^{1}$, Many $M-C^{1}$

${ }^{1} \mathrm{UCL}, \mathrm{MORF}$, Brussels, Belgium, ${ }^{2} \mathrm{UCL}$, ENDO, Brussels, Belgium, ${ }^{3} \mathrm{UCL}$, Endocrinology, Brussels, Belgium, ${ }^{4} \mathrm{UCL}$, Surgery, Brussels, Belgium

\section{$09.30-09.45$}

OP53 THYROID-STIMULATING AUTOANTIBODIES ARE PREVALENT IN PATIENTS WITH HASHIMOTO'S THYROIDITIS AND ASSOCIATED ORBITOPATHY A PROSPECTIVE, CONTROLLED TRIAL

Diana $T^{1}$, Kanitz $M^{1}$, Cronau $M^{1}$, Matheis $N^{1}$, Kahaly GJ

${ }^{1}$ Gutenberg University Medical Center, Molecular Thyroid Research Laboratory, Mainz, Germany

\subsection{5-10.00}

OP54 HLA CLASS II HAPLOTYPES AND GENOTYPES DIFFERENTIATE BETWEEN THYROID AND POLYGLANDULAR AUTOIMMUNITY

Flesch BK ${ }^{1}$, Matheis $N^{2}$, Alt $T^{3}$, Bux $J^{1}$, Kahaly $G J^{2}$

${ }^{1}$ German Red Cross Blood Service West Hagen and Bad Kreuznach, Laboratory of Immunogenetics/HLA, Bad Kreuznach, Germany, ${ }^{2}$ Gutenberg University Medical Center, Molecular Thyroid Research Laboratory, Mainz, Germany, ${ }^{3}$ German Red Cross Blood Service West, Hagen and Bad Kreuznach, Bioinformatics Unit, Bad Kreuznach, Germany
Aalmarkt Zaal

08.00-10.00

Oral Session 8:

Thyroid Cancer Clinical 2 (OP55-OP62)

Chairpersons: Gabriella Pellegriti, Italy

Pim Burger, The Netherlands

08.00-08.15

OP55 PROPHYLACTIC CENTRAL COMPARTMENT LYMPH NODE DISSECTION (CCND) DOES NOT IMPROVE THE OUTCOME OF PAPILLARY THYROID CANCER (PTC) PATIENTS: RESULTS FROM THE FIRST PROSPECTIVE COHORT STUDY

Valerio $L^{1}$, Viola $D^{1}$, Materazzi $G^{2}$, Miccoli $P^{2}$, Basolo $F^{3}$, Sensi $E^{3}$, Faviana $P^{3}$, Molinaro $E^{1}$, Agate $L^{1}$, Elisei $R^{1}$

${ }^{1}$ Endocrine Unit, Department of Clinical and Experimental Medicine, University of Pisa, Pisa, Italy, ${ }^{2}$ Department of Surgery, University of Pisa, Pisa, Italy, ${ }^{3}$ Department of Surgical, Medical and Molecular Pathology of the Clinical Area, University of Pisa, Pisa, Italy

08.15-08.30

OP56 ARE PAPILLARY THYROID MICROCARCINOMA WITH MINIMAL EXTRA-THYROIDAL INVASION AT HIGH RISK OF RECURRENCE?

Buffet $C^{1,2}$, Chéraud $N^{2,3}$, Trésallet $C^{2,3}$, Lupinacci $R^{2,3}$, Godiris-Petit $G^{2,3}$, Tissier $F^{4,5}$, Leenhardt $L^{1,2}$, Ménégaux $F^{2,3}$ ${ }^{1}$ APHP- Pitié-Salpêtrière Hospital, Nuclear Medicine, Thyroid Department, Paris, France, ${ }^{2}$ Pierre et Marie Curie University (Paris VI), Paris, France, ${ }^{3}$ APHP- Pitié-Salpêtrière Hospital, Endocrine Surgery, Paris, France, ${ }^{4}$ APHP- Pitié-Salpêtrière Hospital, Pathology Department, Paris, France, ${ }^{5}$ Descartes University (Paris V), Paris, France

08.30-08.45

OP57 IMMUNOHISTOCHEMICAL ASSAY OF THE BRAF ${ }^{\text {V600E. }}$ MUTATED PROTEIN IN PAPILLARY THYROID CARCINOMA AND COMPARISON WITH SEQUENCING ANALYSIS

Colato $C^{1}$, Marchetti $I^{2}$, Piccoli $P^{1}$, Montagna $L^{1}$, Di Coscio $G^{2}$, Brazzarola $P^{3}$, Chilosi $M^{1}$, Ferdeghini $M^{1}$

${ }^{1}$ University of Verona, Pathology and Diagnostics, Verona, Italy, ${ }^{2}$ University of Pisa, Surgical, Molecular, and Ultrastructural Pathology, Pisa, Italy, ${ }^{3}$ University of Verona, Surgery and Oncology, Verona, Italy

08.45-09.00

OP58 THE B-RAF ${ }^{\text {V600E }}$ MUTATION IS NOT ASSOCIATED WITH POORER CLINICAL PROGNOSIS IN PAPILLARY THYROID CANCER

Scheffel RS ${ }^{1}$, Romitti $M^{1}$, Ceolin $L^{1}$, Antunes $D^{1}$, Pinto Ribeiro RV ${ }^{1}$, Dora $J M^{1}$, Maia $A L^{1}$

${ }^{1}$ Thyroid Section, Endocrine Division, Hospital de Clínicas de Porto Alegre, Universidade Federal do Rio Grande do Sul, Porto Alegre, Brazil 


\section{Personalized Approach in the Management of Well-Differentiated Thyroid Cancer}

\section{TUESDAY, $\mathbf{1 0}^{\text {th }}$ September}

Leiden, The Netherlands

13.00-14.00 Genzyme Symposium

City Music Hall, Grote Zaal/Main Auditorium

program \& speakers

Chair: Prof. Jan Smit

Radboud University Nijmegen Medical Center, The Netherlands

How to manage FNA indeterminate results

Speaker: Prof. Erik Alexander,

Brigham \& Women's Hospital/Harvard Medical School, Boston, USA

Ablation with low dose radioiodine

Speaker: Dr. Steve Hyer,

Epsom \& St Helier University Hospitals NHS Trust, London, UK

Risk re-stratification - role of stimulated Tg test

Speaker: Prof. Rossella Elisei,

Dept. Endocrinology and Metabolism, University of Pisa, Italy

$1^{\text {st }}$ Thyroid

Cancer

Awareness

Run
MONDAY, $9^{\text {th }}$ September

Time: 7.00 hrs

Place: Leiden, City Center

Starting point: Stadsgehoorzaal/City Music Hall, back entrance

Route: To Be Confirmed

Distance: $3 \mathrm{Km}$

Registration:

online: ETA congress site

on site: Genzyme Booth No.7, Breezaal Hall 
$09.00-09.15$

OP59 HER-2 EXPRESSION IN DIFFERENTIATED THYROID

CARCINOMA (DTC): AN IMMUNOHISTOCHEMICAL CHARACTERIZATION IN VIEW OF TARGETED THERAPIES

Giovinazzo $S^{1}$, Campenni $A^{2}$, Simone $A^{3}$, Benvenga $S^{1}$, Tuccari $G^{3}$, Trimarchi $F^{1}$, Ruggeri $R M^{1}$

'University of Messina, Dep of Clinical and Experimental Medicine, Messina, Italy, ${ }^{2}$ University of Messina, Unit of Nuclear Medicine, Messina, Italy, ${ }^{3}$ University of Messina, Department of Pathology, Messina, Italy

$09.15-09.30$

OP60 INCIDENTAL THYROID CANCER: EPIDEMIOLOGICAL, CLINICAL AND MOLECULAR ANALYSES IN A LARGE SERIES OF PATIENTS TREATED FOR BENIGN DISEASES

De Leo $S^{1}$, Perrino $M^{1}$, Badiali $S^{2}$, Rossi $S^{3}$, Cirello V', Colombo C', Beck-Peccoz $P^{1}$, Vicentini $L^{2}$, Fugazzola $L^{1}$

${ }^{1}$ University of Milan, Milan, Italy, ${ }^{2}$ Fondazione IRCCS

Ca' Granda, Endocrine Surgery Unit, Milan, Italy, ${ }^{3}$ Unit of Pathological Anatomy, San Paolo Hospital Medical School, Milan, Italy

\subsection{0-09.45}

OP61 IMMUNOHISTOCHEMICAL AND BIOCHEMICAL EVIDENCE THAT MEDULLARY THYROID CARCINOMA (MTC) CAN SECRETE CARBOHYDRATE ANTIGEN 19.9 (CA 19.9) Lorusso $L^{1}$, Romei $C^{1}$, Pani $F^{2}$, Guerini $A^{3}$, Menghi $A^{3}$, Poletti $A^{3}$, Torregrossa $L^{4}$, Agate $L^{1}$, Bottici $V^{1}$, Molinaro $E^{1}$, Vitti $P^{1}$, Elisei $R^{1}$ ${ }^{1}$ Endocrine Unit, Department of Clinical and Experimental Medicine, University of Pisa, Pisa, Italy, ${ }^{2}$ University Hospital of Cagliari, Cagliari, Italy, ${ }^{3}$ Department of Laboratory Medicine, Anatomy and Histopathology, Bassano Del Grappa, Italy, ${ }^{4}$ Department of Surgical, Medical and Molecular Pathology of the Clinical Area, University of Pisa, Pisa, Italy

09.45-10.00

OP62 ATYPIA OF UNDETERMINED SIGNIFICANCE AT CYTOLOGY: PREDICTION OF MALIGNANCY BY US AND COMPARISON OF FURTHER MANAGEMENT

Lee $K H^{1}$, Shin $J H^{2}$, Han $B-K^{2}, K o E Y^{2}$

${ }^{1}$ Inje University Haeundae Paik Hospital, Radiology, Busan, Korea, Republic of, ${ }^{2}$ Samsung Medical Center, Sungkyunkwan University School of Medicine, Radiology, Seoul, Republic of Korea

10.00-10.30 Coffee break
Grote Zaal/Main Auditorium

10.30-12.00

Symposium 5 (Translational): Obesity and the Thyroid

Chairpersons: Colin Dayan, UK

Marco Medici, The Netherlands

10.30-11.00 Adipocytes and the thyroid Marian Ludgate, UK

11.00-11.30 Thyroid function and body composition Peter Laurberg, Denmark

11.30-12.00 Effects of obesity and metformin treatment Luca Chiovato, Italy

Aalmarkt Zaal

$10.30-12.00$

Symposium 6 (Translational): Molecular Aspects of Thyroid Cancer

Chairpersons: Agnieszka Piekielko-Witkowska, Poland Jan Smit, The Netherlands

10.30-11.00 miRNA in thyroid cancer

Alfredo Fusco, Italy

11.00-11.30 BRAF mutations in thyroid cancer Carmelo Nucera, USA

11.30-12.00 Gene expression profiles of thyroid cancer Barbara Jarzab, Poland

Poster Area

$12.00-13.00$

Lunch and Poster Discussion 3 (Posters 184-275) (see pages 57 to 65)

Poster Session 21: Thyroid Cancer Diagnostics 3

Chairperson: Kalliopi Pazaitou-Panayiotou, Greece

Poster Session 22: Thyroid Cancer Diagnostics 4

Chairperson: Valeriano Leite, Portugal

Poster Session 23: Thyroid Cancer Therapeutics 3

Chairperson: Françoise Borson-Chazot, France

Poster Session 24: Thyroid Cancer Therapeutics 4

Chairperson: Lionel Groussin, France

Poster Session 25: Case Reports 3

Chairperson: Valentin Fadeyev, Russia

Poster Session 26: Imaging

Chairperson: Markus Luster, Germany

Poster Session 27: Thyroid Hormone Metabolism and Action

Chairperson: Maria Jesus Obregòn, Spain

Poster Session 28: Medullary Thyroid Cancer

Chairperson: Laura Fugazzola, Italy

Poster Session 29: Thyroid Nodules and Goitre 2

Chairperson: Ralf Paschke, Germany

Poster Session 30: Thyroid in Reproduction and

Development

Chairperson: Peter Bisschop, The Netherlands 
Grote Zaal/Main Auditorium

13.00-14.00

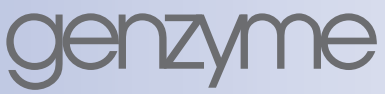

A SANOFI COMPANY

Genzyme Symposium

\section{Personalized Approach in the Management of Well-Differentiated Thyroid Cancer}

13.00-13.05 Welcome and Introduction Jan Smit, The Netherlands

13.05-13.20 How to manage FNA indeterminate results

Erik Alexander, USA

13.20-13.35 Ablation with low dose radioiodine Steve Hyer, UK

13.35-13.50 Risk re-stratification - the role of stimulated Tg test Rossella Elisei, Italy

13.50-14.00 Final discussion and symposium close Jan Smit, The Netherlands

14.00-14.45

Meet the Expert 9-12

Waalse Kerk

$14.00-14.45$

MTE 9 (Basic)

Thyroid hormone action in muscle

differentiation

Domenico Salvatore, Italy

Kleine Foyer

$14.00-14.45$

MTE 10 (Clinical)

Lessons from the pathology report in differentiated thyroid carcinoma

Sofia Tseleni-Balafouta, Greece

\section{Aalmarkt Zaal} $14.00-14.45$

MTE 11 (Clinical)

ETA guidelines on genetic screening of medullary thyroid carcinoma Rossella Elisei, Italy

Grote Zaal/Main Auditorium

14.00-14.45

MTE 12 (Clinical)

Can we prevent Graves' orbitopathy?

Petros Perros, UK

$14.45-15.00$

Coffee break
Grote Zaal/Main Auditorium

\section{$15.00-17.00$}

Oral Session 9:

Clinical Thyroidology 2 (OP63-OP70)

Chairpersons: Laurence Leenhardt, France

Georg Hennemann, The Netherlands

$15.00-15.15$

OP63 THE RELATIONSHIP BETWEEN TSH AND FREE T4

IN A LARGE POPULATION IS COMPLEX, NON-LINEAR AND DIFFERS BY AGE AND GENDER

Hadlow $N C^{1,2}$, Rothacker KM' ${ }^{3}$, Wardrop $R^{2}$, Brown $S^{3}{ }^{3}$, Lim $E M^{2,3}$, Walsh $\mathrm{JP}^{3,4}$

${ }^{1}$ Western Diagnostic Pathology, Myaree, Australia, ${ }^{2}$ PathWest Laboratory Medicine, Nedlands, Australia, ${ }^{3}$ Sir Charles Gairdner Hospital, Department of Endocrinology and Diabetes, Nedlands, Australia, ${ }^{4}$ University of Western Australia, School of Medicine and Pharmacology, Crawley, Australia

$15.15-15.30$

OP64 HOMOZYGOUS RESISTANCE TO THYROID HORMONE: CAN THE COMBINATION OF TRIAC AND CARBIMAZOLE PREVENT CARDIAC COMPLICATIONS?

Moran $C^{1}$, Habeb $A^{2}$, Kydd $A^{3}$, Kahaly $G^{4}$, Mohr-Kahaly $S^{5}$, Kampmann $C^{5}$, Lyons $G^{1}$, Rajanayagam $O^{1}$, Schoenmakers $E^{1}$, Halsall $D^{6}$, Mollon $J^{7}$, Baguley $D^{8}$, Morsy $M^{2}$, Chatterjee VK ${ }^{1}$ ${ }^{1}$ Institute of Metabolic Science, Cambridge, United Kingdom, ${ }^{2}$ Maternity \& Childrens Hospital \& Taibah University, Paediatric Department, Al-Madinah, Saudi Arabia, ${ }^{3}$ Addenbrookes Hospital, Cardiology Dept, Cambridge, United Kingdom, ${ }^{4} J o h a n n e s$ Gutenberg University Medical Center, Department of Medicine, Mainz, Germany, ${ }^{5}$ Johannes Gutenberg University Medical Center, Department of Cardiology, Mainz, Germany, ${ }^{6}$ Addenbrookes Hospital, Department of Biochemistry, Cambridge, United Kingdom, ${ }^{7}$ University of Cambridge, Department of Experimental Psychology, Cambridge, United Kingdom, ${ }^{8}$ Addenbrookes Hospital, Department of Audiology, Cambridge, United Kingdom

$15.30-15.45$

OP65 COGNITIVE FUNCTIONS IN PRIMARY HYPOTHYROIDISM AFTER LONG-TERM SUBSTITUTION Djurovic $M M^{1}$, Pereira $A M^{2}$, Pavlovic $D^{3}$, Salak $B^{4}$, Jemuovic $Z H^{1}$, Jankovic $D^{1}$, Petakov $M^{1}$, Djukic $V^{5}$, Damjanovic $S^{1}$

${ }^{1}$ Institute of Endocrinology, Diabetes and Diseases of Metabolism, Clinical Centre of Serbia, Belgrade, Serbia, ${ }^{2}$ Department of Endocrinology and Metabolic Diseases Leiden University Medical Center, Leiden, Netherlands, ${ }^{3}$ Faculty of Philosophy, University of Belgrade, Belgrade, Serbia, ${ }^{4}$ Institute of Neurology, Clinical Centre of Serbia, Belgrade, Serbia, ${ }^{5}$ Emergency Center, Clinical Centre of Serbia, Belgrade, Serbia 
$15.45-16.00$

OP66 EVALUATING THE PREVALENCE OF THYROTROPIN

RECEPTOR (TSHR) INACTIVATING MUTATIONS IN ADULTS

WITH SUBCLINICAL HYPOTHYROIDISM (SH); IMPACT ON

BONE DENSITY

de Lloyd $A C^{1}$, Bakhsh $A^{1}$, Zhang $L^{1}$, Evans $C^{2}$, Dodd $A^{2}$, Durrant $H^{2}$, Neale $S^{2}$, Mitchem $K^{2}$, Whatley $S^{2}$, Rees $D A^{1}$, Ludgate $M^{1}$

${ }^{1}$ IMEM, Cardiff University School of Medicine, University Hospital of Wales, Cardiff, United Kingdom, ${ }^{2}$ Department of Medical Biochemistry, Cardiff \& Vale University Health Board, Cardiff, United Kingdom

$16.00-16.15$

OP67 TPO ANTIBODIES ARE ASSOCIATED WITH A LOWER LIVE BIRTH RATE IN WOMEN WITH RECURRENT MISCARRIAGE

Vissenberg $R^{1}$, Fliers $E^{2}$, van der Post $J A M^{3}$, van Wely $M^{1}$, Bisschop $\mathrm{PH}^{2}$, Goddijn $\mathrm{M}^{1}$

${ }^{1}$ Academic Medical Centre, Centre for Reproductive Medicine, Amsterdam, Netherlands, ${ }^{2}$ Academic Medical Centre,

Endocrinology and Metabolism, Amsterdam, Netherlands,

${ }^{3}$ Academic Medical Centre, Obstetrics and Gynaecology,

Amsterdam, Netherlands

$16.15-16.30$

OP68 90\% OF PREGNANT WOMEN WILL BE MISCLASSIFIED BY THE USE OF PREDETERMINED FREE T4 REFERENCE RANGES FROM DIFFERENT LABORATORIES

Bliddal $S^{1}$, Feldt-Rasmussen $U^{1}$, Boas $M^{2}$, Faber $J^{3}$, Juul $A^{4}$, Precht $D H^{5}$

${ }^{1}$ Copenhagen University Hospital (Rigshospitalet), Department of Endocrinology, Copenhagen, Denmark, ${ }^{2}$ Copenhagen University Hospital (Hillerød), Department of Pediatrics, Hillerød, Denmark, ${ }^{3}$ Copenhagen University Hospital (Herlev), Herlev, Denmark, ${ }^{4}$ Copenhagen University Hospital (Rigshospitalet), Department of Growth and Reproduction, Copenhagen, Denmark, ${ }^{5}$ Copenhagen University Hospital (Hvidovre), Family Outpatient Clinic, Copenhagen, Denmark

\section{$16.30-16.45$}

OP69 HIGH PREVALENCE OF THYROID DISORDERS IN PREGNANT WOMEN IN A MILDLY IODINE-DEFICIENT COUNTRY: A POPULATION-BASED STUDY

Moreno-Reyes $R^{1}$, Glinoer $D^{2}$, Van Oyen $H^{3}$, Vandevijvere $S^{3}$

${ }^{1}$ Université Libre de Bruxelles, Department of Nuclear Medicine, Hôpital Erasme, Brussels, Belgium, ${ }^{2}$ Université Libre de Bruxelles, Division of Endocrinology, Hôpital Saint-Pierre, Brussels, Belgium, ${ }^{3}$ Scientific Institute of Public Health, Department of Public Health and Surveillance, Brussels, Belgium
$16.45-17.00$

OP70 IS THYROID HYPOFUNCTION A TRUE FEATURE OF BREAST CANCER?

Smyth PP ${ }^{1,2}$, Mc Dermott EWM ${ }^{1}$, O'Higgins $\mathrm{NJ}^{1}$

${ }^{1}$ University College Dublin, School of Medicine, Dublin, Ireland, ${ }^{2}$ National University of Ireland, Galway, School of Physics, Galway, Ireland

Aalmarkt Zaal

$15.00-17.00$

Oral Session 10:

Thyroid Cancer Basic (OP71-OP78)

Chairpersons: Corinne Dupuy, Belgium Pilar Santisteban, Spain

$15.00-15.15$

OP71 THYROID CANCER SUSCEPTIBILITY GENE FOXE1 PROMOTES CELL MOTILITY AND IS REQUIRED FOR SURVIVAL OF ADULT THYROID CELLS

De Menna $M^{1}$, Marotta $P^{2}$, Esposito $R^{1}$, Orlacchio $A^{2}$, De Vita $G^{1}$, Garbi $C^{1}$, De Felice $M^{2}$, Di Lauro $R^{1}$

'Università degli Studi di Napoli 'Federicoll', Dipartimento di Medicina Molecolare e Biotecnologie Mediche, Napoli, Italy,

${ }^{2}$ Biogem s.c.a.r.l., Ariano Irpino, Italy

$15.15-15.30$

OP72 INHIBITION OF MTOR SIGNALING INDUCES APOPTOSIS AND TTF-1 DEPENDENT REDIFFERENTIATION OF THYROID CARCINOMA CELL LINES

Plantinga $T S^{1}$, Heinhuis $B^{1}$, Joosten $L A B^{2}$, Netea $M G^{2}$, Hermus $A R M M^{1}$, Schweppe $R E^{3}$, Haugen $B R^{3}$, Smit JWA ${ }^{2}$, Netea-Maier $R T^{1}$

${ }^{1}$ Radboud University Nijmegen Medical Center, Department of Medicine, Division of Endocrinology, Nijmegen, Netherlands, ${ }^{2}$ Radboud University Nijmegen Medical Center, Department of Medicine, Nijmegen, Netherlands, ${ }^{3}$ University of Colorado Denver, Department of Medicine, Division of Endocrinology, Metabolism, and Diabetes, Aurora, United States

$15.30-15.45$

OP73 ISOLATION OF NOVEL TARGETS GENES OF TWIST1 IN ANAPLASTIC THYROID CARCINOMA

Orlandella $F M^{1}$, Di Maro $G^{1}$, Salerno $P^{1}$, Santoro $M^{1}$, Salvatore $G^{2}$ ${ }^{1}$ Universita di Napoli Federico II, Napoli, Italy, ${ }^{2}$ Università di Napoli Parthenope, Napoli, Italy

$15.45-16.00$

OP74 CROSSTALK BETWEEN WNT/BETA-CATENIN AND PI3K/AKT SIGNALING PATHWAY IN THYROID CANCER Sastre-Perona $A M^{1}$, Riesco-Eizaguirre $G^{1}$, Santisteban Sanz $P^{1}$ ${ }^{1}$ Instituto de Investigaciones Biomédicas (CSIC-UAM), Molecular Fisiopathology, Madrid, Spain 
16.00-16.15

OP75 RESISTANCE OF ANAPLASTIC THYROID CANCER TO BRAF(V600E) INHIBITION THROUGH FEEDBACK ACTIVATION OF EGFR

Koh $Y^{1} W^{1}$, Yang $\mathrm{YJ}^{1}$, Na HJ', Kim W-S ${ }^{1}$, Bong JP', Baek SJ', Kim JW', Park $\mathrm{JH}^{3}$, Shin $\mathrm{VY}^{4}$, Hong $\mathrm{HJ}^{7}$, Kwon $\mathrm{JH}^{1}$, Lee EJ ${ }^{4}$, Choi EC ${ }^{7}$

'Yonsei University College of Medicine, Otorhinolaryngology, Seoul, Republic of Korea, ${ }^{2}$ Soonchunhyang University Hospital, Otolaryngology-Head and Neck Surgery, Seoul, Republic of Korea, ${ }^{3}$ Soonchunhyang University Hospital, OtolaryngologyHead and Neck Surgery, Cheonan, Republic of Korea, ${ }^{4}$ Yonsei University College of Medicine, Endocrinology, Seoul, Republic of Korea

\section{$16.15-16.30$}

OP76 AN INTRONIC DELETION IN PHOSPHOLIPASE-C $\beta 1$ (PLC $\beta 1$ ) IS ASSOCIATED WITH EUTHYROID MULTINODULAR GOITRE (MNG) PROGRESSING TO PAPILLARY THYROID CANCER (PTC)

Grennan-Jones $F A^{1}$, Bakhsh $A^{1}$, Hampshere $M^{2}$, Gregory ${ }^{3}$, Kirov $G^{2}$, Williams $D^{4}$, Bullock $M^{5}$, Clifton-Bligh $R^{5}$, Ludgate $M^{1}$ ${ }^{1}$ Cardiff University, Thyroid Research Group, Institute of Molecular and Experimental Medicine, Cardiff, United Kingdom, ${ }^{2}$ Cardiff University, Institute of Psychological Medicine \& Clinical Neurosciences, Cardiff, United Kingdom, ${ }^{3}$ Cardiff University, Dept of Child Health, Institute of Molecular and Experimental Medicine, Cardiff, United Kingdom, ${ }^{4}$ Cambridge University, Strangeways Research Laboratory, Cambridge, United Kingdom, ${ }^{5}$ University of Sydney, Kolling Institute of Medical Research, Sydney, Australia
$16.30-16.45$

OP77 MOLECULAR CONSEQUENCES OF BRAFV600E MUTATION EVALUATED IN A MOUSE MODEL

Rusinek $D^{1}$, Swierniak $M^{1}$, Chmielik $E^{2}$, Kowalska $M^{1}$, Kowal $M^{1}$, Widlak $W^{3}$, Jarzab $B^{1}$

${ }^{1} \mathrm{MSC}$ Memorial Cancer Center and Institute of Oncology, Gliwice Branch, Department of Nuclear Medicine and Endocrine Oncology, Gliwice, Poland, ${ }^{2}$ MSC Memorial Cancer Center and Institute of Oncology, Gliwice Branch, Department of Tumor Pathology, Gliwice, Poland, ${ }^{3}$ MSC Memorial Cancer Center and Institute of Oncology, Gliwice Branch, Center for Translational Research and Molecular Biology of Cancer, Gliwice, Poland

$16.45-17.00$

OP78 POSSIBLE MODIFIER ROLE FOR THE RET FUNCTIONAL POLYMORPHISM G691S

Colombo $C^{1}$, Rizzetti $M G^{2}$, Mondellini $P^{2}$, Romeo $P^{2}$, Minna $E^{2}$, Greco $A^{2}$, Fugazzola $L^{1}$, Borrello $M G^{2}$

${ }^{1}$ University of Milan, Department of Clinical Sciences and Community Health, Endocrinology and Diabetology Unit, Fondazione IRCCS Ca' Granda, Milan, Italy, ${ }^{2}$ Fondazione IRCCS Istituto Nazionale dei Tumori, Department of Experimental Oncology and Molecular Medicine, Molecular Mechanism Unit, Milan, Italy 


\section{Grote Zaal/Main Auditorium}

17.00-17.45

\section{Special Lecture in Honour of Georg Hennemann}

Chairpersons: Theo Visser, The Netherlands Luigi Bartalena, Italy

Non-thyroidal illness: a syndrome with different faces Greet Van den Berghe, The Netherlands

\section{Grote Zaal/Main Auditorium}

18.00-19.15

\section{ETA General Assembly}

(For Members only)

\subsection{Gala Dinner at the National Museum of Antiquities}
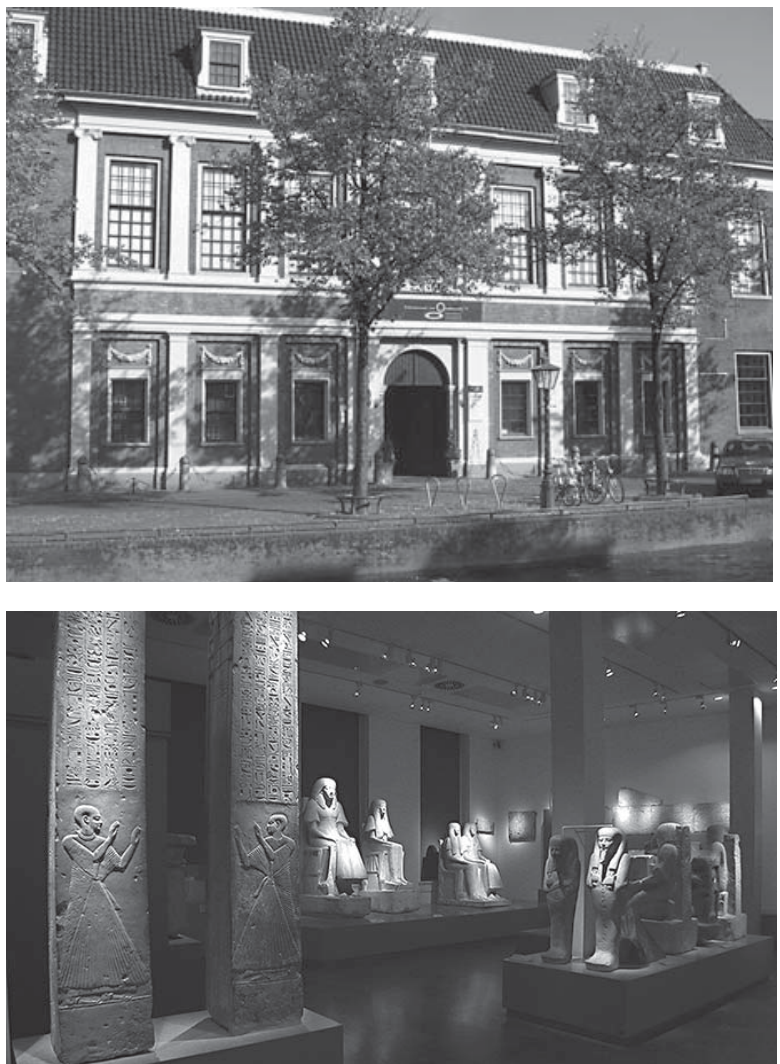

Photos: Courtesy of the Rijksmuseum van Oudheden 
Aalmarkt Zaal

07.45-08.45

\section{Short-Call Abstracts}

\section{Aalmarkt Zaal}

08.45-10.45

\section{Oral Session 11:}

Graves' Orbitopathy (OP79-OP86)

Chairpersons: Luigi Bartalena, Italy Maarten Soeters, The Netherlands

08.45-09.00

OP79 PROTEOMIC PROFILE OF ORBITAL TISSUE IN GRAVES' ORBITOPATHY

Matheis $N^{1}$, Grus $F^{2}$, Diana $T^{1}$, Ponto $K^{3}$, Pitz $S^{3}$, Kahaly GJ $J^{1}$ ${ }^{1}$ Gutenberg University Medical Center, Molecular Thyroid Research Laboratory, Mainz, Germany, ${ }^{2}$ Gutenberg University Medical Center, Laboratory of Experimental Ophthalmology, Mainz, Germany, ${ }^{3}$ Gutenberg University Medical Center, Department of Ophthalmology, Mainz, Germany

09.00-09.15

OP80 POSSIBLE TARGETS FOR NONIMMUNOSUPPRESSIVE THERAPY OF GRAVES' ORBITOPATHY (GO)

Zhang $L^{1}$, Grennan-Jones $F^{1}$, Draman $M S^{1}$, Lane $C^{2}$, Dayan $C M^{1}$, Ludgate $M^{1}$

${ }^{1}$ Cardiff University, Institute of Molecular and Experimental Medicine, School of Medicine, Cardiff, United Kingdom, ${ }^{2}$ Cardiff \& Vale University Health Board, Heath Park, Department of Ophthalmology, Cardiff, United Kingdom

09.15-09.30

OP81 IMMEDIATE EARLY GENES ARE OVEREXPRESSED IN SMOKERS WITH GRAVES' OPHTHALMOPATHY COMPARED TO NON-SMOKERS

Planck $T^{1,2}$, Shahida $B^{1}$, Parikh $H^{1,3}$, Åsman $P^{4,5}$, Hallengren $B^{1,2}$, Lantz $M^{1,2}$

${ }^{1}$ Lund University, Dpt. of Clinical Sciences, Diabetes and Endocrinology, Malmö, Sweden, ${ }^{2}$ Skåne University Hospital, Dpt. of Endocrinology, Malmö, Sweden, ${ }^{3}$ Laboratory of

Translational Genomics, Division of Cancer Epidemiology and Genetics, National Cancer Institute, National Institutes of Health, Bethesda, Maryland, United States, ${ }^{4}$ Lund University, Dpt. of Clinical Sciences, Ophthalmology, Malmö, Sweden, ${ }^{5}$ Skåne University Hospital, Dpt. of Ophthalmology, Malmö, Sweden
09.30-09.45

OP82 THYROID STIMULATING AUTOANTIBODIES

INDICATE THE ONSET OF DYSTHYROID OPTIC NEUROPATHY

Ponto $K^{1}$, Diana $T^{2}$, Kanitz $M^{2}$, Matheis $N^{2}$, Kahaly $G J^{2}$

${ }^{1}$ Gutenberg University Medical Center, Department of Ophthalmology, Mainz, Germany, ${ }^{2}$ Gutenberg University Medical Center, Department of Medicine I, Mainz, Germany

\subsection{5-10.00}

\section{OP83 COMPARISON OF EARLY TOTAL THYROIDECTOMY} WITH ANTITHYROID TREATMENT IN PATIENTS WITH MODERATE TO SEVERELY ACTIVE GRAVES' ORBITOPATHY, A RANDOMIZED PROSPECTIVE TRIAL

Erdoğan $M F^{1}$, Demir $\ddot{O}^{1}$, Ersoy $R \ddot{U}^{2}$, Gül $K^{2}$, Ünlütürk $U^{1}$, Aydoğan $B i^{1}, \ddot{U} c ̧ Z A^{3}$, Mete $T^{4}$, Ertek $S^{5}$, Çakır B2 ${ }^{2}$, Güler $S^{4}$, Çorapçıŏlu $D^{1}$, Dağdelen $S^{6}$, Erdoğan $G^{5}$

${ }^{1}$ Ankara University School of Medicine, Endocrinology and Metabolic Diseases, Ankara, Turkey, ${ }^{2}$ Yıldırım Beyazıt University, School of Medicine, Endocrinology and Metabolic Diseases, Ankara, Turkey, ${ }^{3}$ Ankara Educational and Research Hospital, Endocrinology and Metabolic Diseases, Ankara, Turkey, ${ }^{4}$ Ankara Numune Educational and Research Hospital, Endocrinology and Metabolic Diseases, Ankara, Turkey ${ }^{5}$ Ufuk University School of Medicine, Endocrinology and Metabolic Diseases, Ankara, Turkey, ${ }^{6}$ Hacettepe University, School of Medicine, Endocrinology and Metabolic Diseases, Ankara, Turkey

$10.00-10.15$

OP84 LACK OF OCCURRENCE OF GRAVES' ORBITOPATHY (GO) AFTER RADIOIODINE (RAI) THERAPY WITH AND WITHOUT STEROID PROPHYLAXIS: A PROSPECTIVE STUDY Vannucchi GM ${ }^{1}$, Covelli $D^{1}$, Campi I ${ }^{1}$, Currò $N^{2}$, Dazzi $D^{3}$, Rodari $M^{4}$, Pepe $G^{4}$, Chiti $A^{4}$, Beck-Peccoz $P^{1}$, Salvi $M^{1}$

${ }^{1}$ Endocrine Unit, Fondazione IRCCS Cà Granda, Milan, Italy, ${ }^{2}$ Ophthalmology, Fondazione IRCCS Cà Granda, Milan, Italy, IInternal Medicine, Ospedale di Fidenza, Fidenza, Italy,

${ }^{4}$ Nuclear Medicine, Istituto Clinico Humanitas, Rozzano, Italy

\section{$10.15-10.30$}

\section{OP85 IMPACT OF PREVIOUS ORBITAL IRRADIATION} ON THE OUTCOME OF DECOMPRESSION SURGERY IN DYSTHYROID ORBITOPATHY

Grunenwald $S^{1}$, Jalbert $F^{2}$, Leray $B^{3}$, Imbert $P^{4}$, Bachaud J- $M^{5}$, Boutault $F^{2}$, Caron $P^{1}$

${ }^{1} \mathrm{CHU}$ Larrey, Endocrinology and Metabolic Diseases, Toulouse, France, ${ }^{2} \mathrm{CHU}$ Purpan, Maxillo-facial Unit, Toulouse, France, ${ }^{3} \mathrm{CHU}$ Toulouse, Department of Ophthalmology, Toulouse, France, ${ }^{4}$ Clinique du Parc, Ophthalmology, Toulouse, France, ${ }^{5}$ Institut Claudius Regaud, Radiotherapy, Toulouse, France 
$10.30-10.45$

OP86 DIFFERENTIAL MODULATION OF CXCL8

CHEMOKINE, IN COMPARISON WITH CXCL10, BY

CYTOKINES IN HUMAN THYROCYTES IN GRAVES' DISEASE AND IN PRIMARY FIBROBLASTS OR PREADIPOCYTES FROM GRAVES' OPHTHALMOPATHY

Ferrari $S M^{1}$, Fallahi $P^{1}$, Ruffilli $I^{1}$, Corrado $A^{1}$, Nardi $^{1}{ }^{1}$,

Sellari-Franceschini $S^{1}$, Antonelli $A^{1}$

${ }^{1}$ University of Pisa, Pisa, Italy

\section{Kleine Foyer}

08.45-10.45

Oral Session 12:

Thyroid Hormone Transporters and

Deiodinases (OP87-OP94)

Chairpersons: Ulrich Schweizer, Germany

Heike Heuer, Germany

08.45-09.00

OP87 KNOCKDOWN OF TYPE 3 IODOTHYRONINE

DEIODINASE DISTURBS EMBRYONIC AND LARVAL DEVELOPMENT IN ZEBRAFISH

Heijlen $M^{1}$, Bagci $E^{2}$, Houbrechts $A^{1}$, Knapen $D^{2,3}$, Darras VM ${ }^{1}$

${ }^{1} \mathrm{KU}$ Leuven, Laboratory of Comparative Endocrinology,

Department of Biology, Leuven, Belgium, ²University of

Antwerp, Systemic Physiological \& Ecotoxicological Research,

Department of Biology, Antwerpen, Belgium, ${ }^{3}$ University of

Antwerp, Veterinary Physiology and Biochemistry,

Department of Veterinary Sciences, Antwerpen, Belgium

09.00-09.15

OP88 THYROID HORMONE INACTIVATION IS ESSENTIAL FOR THE PROLIFERATION OF MUSCLE STEM CELLS AND

THE REGENERATION PROCESS

Dentice $M^{1}$, Ambrosio $R^{1}$, Luongo $C^{1}$, Alfano $F^{1}$, Langella $M^{1}$,

Salvatore $D^{1}$

${ }^{1}$ University of Naples Federico II, Clinical Medicine and Surgery,

Naples, Italy

09.15-09.30

OP89 EFFECTIVE TRANSPORT BY THE BILE ACID

TRANSPORTER SLC10A1 EXPLAINS THE LIVER SELECTIVE ACTION OF THE LIPID-LOWERING THYROID HORMONE ANALOGUE EPROTIROME

Kersseboom $S^{1}$, Carlsson $B^{2}$, Visser $T J^{1}$

${ }^{1}$ Erasmus University Medical Center, Department of Internal

Medicine, Rotterdam, Netherlands, ${ }^{2}$ Karo Bio, Huddinge,

Sweden
09.30-09.45

OP90 EXPRESSION PROFILE AND MANIPULATION OF THYROID HORMONE TRANSPORTERS AND DEIODINASES

IN THE DEVELOPING CHICK CEREBELLUM

Delbaere J' , Bourgeois NMA ${ }^{1}$, Van Herck SLJ', Darras VM ${ }^{1}$

${ }^{1} \mathrm{KU}$ Leuven, Laboratory of Comparative Endocrinology,

Leuven, Belgium

09.45-10.00

OP91 LIVER THYROID HORMONE METABOLISM DURING

\section{FASTING}

de Vries $E^{1}$, Eggels $L^{1}$, van Wijk $N^{1}$, Kalsbeek $A^{1}$, Fliers $E^{1}$, Boelen $A^{1}$

${ }^{1}$ AMC Amsterdam, Department of Endocrinology and

Metabolism, Amsterdam, Netherlands

$10.00-10.15$

OP92 3,3'-T2 IS TRANSPORTED BY THE L-TYPE AMINO

ACID TRANSPORTER LAT2

Wittner $M^{1}$, Köhrle $J^{2}$, Schülein $R^{1}$, Krause $G^{1}, \underline{\text { Kinne } A^{1}}$

${ }^{1}$ Leibniz-Institut für Molekulare Pharmakologie, Berlin,

Germany, ${ }^{2}$ Institut für Experimentelle Endokrinologie,

Charité-Universitätsmedizin, Berlin, Germany

$10.15-10.30$

OP93 DECREASED SELENOCYSTEINE (SEC) READTHROUGH BY A PATIENT MUTATION IN THE SEC INSERTION SEQUENCE OF THE TYPE 2 DEIODINASE

Zevenbergen $C^{1}$, Visser $W E^{1}$, Peeters $R P^{1}$, Larsen $P R^{2}$, Chavatte $L^{3}$, Visser $T J^{1}$

${ }^{1}$ Erasmus Medical Center, Internal Medicine, Rotterdam, Netherlands, ${ }^{2}$ Brigham and Women's Hospital, Department of Internal Medicine, Boston, United States, ${ }^{3}$ Centre de Génétique Moléculaire, Département Expression des Gènes, Gif-sur-Yvette Cedex, France

$10.30-10.45$

OP94 DEVELOPMENTAL EXPRESSION PATTERN OF THYROID HORMONE TRANSPORTERS AND DEIODINASES IN THE CHOROID PLEXUS AND BLOOD VESSELS IN THE CHICKEN BRAIN

Van Herck SL ${ }^{1}$, Delbaere J', Bourgeois NM'1, Geysens $S^{1}$, McAllan $B M^{2}$, Richardson $\mathrm{S}^{3}$, Darras VM ${ }^{1}$

${ }^{1} \mathrm{KU}$ Leuven, Laboratory of Comparative Endocrinology, Department of Biology, Leuven, Belgium, ${ }^{2}$ The University of Sydney, Physiology, School of Medical Sciences, and Bosch Institute, Sydney, Australia, ${ }^{3}$ RMIT University, School of Medical Sciences, Melbourne, Australia

10.45-11.00 Coffee break 
Kleine Foyer

$11.00-12.30$

Symposium 7 (Basic): Deiodinases in Local Thyroid Hormone Control

Chairpersons: Monica Dentice, Italy

Warner Simonides, The Netherlands

11.00-11.30 Deiodinases in inflammatory cells Joan Kwakkel, The Netherlands

$11.30-12.00$

$12.00-12.30$

Deiodinases in aging

W. Edward Visser, The Netherlands

Deiodinases in bone

Duncan Bassett, UK
Aalmarkt Zaal

12.30-13.00

Young Investigator Awards, Poster Prizes, Jack Robbins Prize and Closing Ceremony

Furio Pacini, Italy (President)

Colin Dayan, UK (Secretary)

\section{Aalmarkt Zaal}

11.00-12.30

\section{Symposium 8 (Clinical): Pros and Cons of Novel}

Diagnostic Tools for Differentiated Thyroid

\section{Carcinoma}

Chairpersons: Maria Alevizaki, Greece

Thera Links, The Netherlands

11.00-11.20 Molecular genetics of fine needle aspirates

- Markers for benign neoplasia

Richard Kloos, USA

11.20-11.40 - Markers for malignancy

Furio Pacini, Italy

11.40-12.05 Thyroglobulin antibody interferences with thyroglobulin measurements

Carole Spencer, USA

12.05-12.30 Supersensitive Tg assays: clinical application Maria Grazia Castagna, Italy 


\section{Sunday, 8th September 2013}

\section{Poster Exhibition Area \\ 12.00-13.00 \\ Poster Session 1}

\section{P01 Thyroid Autoimmunity Basic}

Chair: Paul Banga, UK

\section{P1 A REDUNDANT ROLE FOR PROPEPTIDE IN HUMAN THYROID PEROXIDASE PROTEIN FOR ITS CELLULAR, ENZYMATIC AND IMMUNOLOGICAL ACTIVITY \\ Godlewska $M^{1}$, Gora $M^{2}$, Buckle $A M^{3}$, Porebski $B T^{3}$, Kemp EH ${ }^{4}$, Sutton $B J^{5}$, Czarnocka $B^{1}$, Banga JP $^{6}$ \\ ${ }^{1}$ Medical Centre of Postgraduate Education, Biochemistry, Warsaw, Poland, ${ }^{2}$ Institute Biochemistry and Biophysics, Genetics, Warsaw, Poland, ${ }^{3}$ Monash University, Biochemistry and Molecular Biology, Clayton, Australia, ${ }^{4}$ University of Sheffield, Human Metabolism, Sheffield, United Kingdom, ${ }^{5}$ King's College London School of Medicine, Cell and Molecular Biophysics, London, United Kingdom, ${ }^{6}$ King's College London School of Medicine, Diabetes and Endocrinology, London, United Kingdom}

\section{P2 ALTERATIONS IN THE HYPOXIC RESPONSE OF ORBITAL FIBROBLASTS FROM GRAVES' ORBITOPATHY PATIENTS}

Berchner-Pfannschmidt $U^{1}$, Müller $M^{1}$, Delos Reyes $B^{2}$, Steuhl K- $P^{1}$, Fandrey $\mathrm{S}^{2}$, Eckstein $A^{7}$

'University of Duisburg-Essen, Department of Ophthalmology, Essen, Germany, ${ }^{2}$ University of Duisburg-Essen, Institute for Physiology, Essen, Germany

\section{P3 ROLE OF IL-12B AND IL-10 GENE POLYMORPHISMS} IN DEVELOPMENT OF HASHIMOTO'S THYROIDITIS Gerenova J' , Avramova $A^{2}$, Stanilova $S^{2}$

${ }^{1}$ Trakia University, Endocrinology, Stara Zagora, Bulgaria,

${ }^{2}$ Trakia University, Molecular Biology, Immunology and Medical Genetics, Stara Zagora, Bulgaria
P4 TNFa (G/A -308) AND TLR-4 (ASP299GLY) POLYMORPHISMS IN TUNISIAN PATIENTS WITH AUTOIMMUNE THYROIDITIS (GRAVES' DISEASE AND HASHIMOTO'S THYROIDITIS)

Haouat $E^{1}$, Boubakri $M^{1}$, Dhaouadi $T^{1}$, Sfar I', Ben Abdallah $T^{1}$, Gorgi $Y^{1}$

${ }^{1}$ Charles Nicolle hospital, Laboratory of Research in Immunology of Renal Transplantation and Immunopathology (LR03SP01), Tunis, Tunisia

\section{P5 HLA-DRB1*0301 AND HLA-DRB1*1101 ARE ASSOCIATED TO GRAVES' DISEASE IN ROMANIAN POPULATION, WHEREAS HLA-DRB1*0101 AND HLA-DRB1*1501 SEEM TO BE PROTECTIVE Martin $\mathrm{CS}^{1,2}{ }^{1}$ Dutescu Ml ${ }^{3}$, Fica SV ${ }^{1,2}$}

${ }^{1}$ Carol Davila University of Medicine and Pharmacy, Endocrinology, Bucharest, Romania, ${ }^{2}$ Elias University Hospital, Endocrinology, Bucharest, Romania, ${ }^{3}$ National Institute of Hematology Transfusion Prof. C Nicolau, National HLA Laboratory, Bucharest, Romania

\section{P6 INTERACTION OF THE IMMUNE REGULATORY GENES WITH THE THYROID SPECIFIC GENES IN THE PREDISPOSITION TO HASHIMOTO'S DISEASE Hubalewska-Dydejczyk $A^{1}$, Jabrocka-Hybel $A^{1}$, Skalniak $A^{1}$, Piątkowski J ${ }^{1}$, Pach $D^{1}$ \\ ${ }^{1}$ Jagiellonian University Medical College, Department of Endocrinology, Krakow, Poland}

\section{P7 THE VALUE OF SOME CLINICAL AND} IMMUNOLOGICAL PARAMETERS IN DETERMINING THE OUTCOMES OF SURGICAL TREATMENT OF AUTOIMMUNE TIREODIT (AIT) COMBINED WITH NODE Ryabchenko $E^{1}$

'State Institution of Health 'Regional Clinical Hospital № 2', Department of Endocrinologycal Surgery, Krasnodar, Russian Federation 
P02 Thyroid Basic

Chair: Josef Köhrle, Germany

P8 HISTONE DEACTETYLASE INHIBITOR VALPROIC ACID IMPAIRS FOLLICLE FORMATION AND ANGIOGENESIS IN THE DIFFERENTIATING THYROID

Gawade S', Hafen $K^{2}$, Szinnai $G^{1}$

${ }^{1}$ Paediatric Endocrinology, and ${ }^{2}$ Paediatric Immunology, Department of Biomedicine, University of Basel and University Children's Hospital Basel, Basel, Switzerland

\section{P9 ALTERED MITOCHONDRIAL FUNCTION IN} PREGNANT WOMEN WITH SUBCLINICAL HYPOTHYROIDISM AND GESTATIONAL HYPERTENSION

Feldthusen $A-D^{1,2,3}$, Larsen $J^{2}$, Pedersen $P L^{2}$, Kristensen $T^{2,3}$, Anthonsen $S^{2}$, Kvetny $\mathrm{J}^{2,4}$

${ }^{1}$ Naestved Hospital, Department of Obstetrics \& Gynecology, Naestved, Denmark, ${ }^{2}$ Naestved Hospital, The Mitochondrial Research Unit, Naestved, Denmark, ${ }^{3}$ University of Copenhagen, Copenhagen, Denmark, ${ }^{4}$ Department of Internal Medicine, University of Southern Denmark, Naestved, Denmark

\section{P10 THYROID FUNCTION AND IODINE DEFICIENCY DISORDERS: AN INTENSIVE STUDY OF 8 HIMALAYAN VILLAGES}

Kathait $A^{1,2}$, Farswan $A^{3}$, Bamola $V^{4}$, Yadav $N^{1}$, Chandola-Saklani $A^{1}$

${ }^{1}$ Apeejay Stya University, Centre for Biosciences \& Clinical Research, Gurgaon, India, ${ }^{2}$ HNBG Central University, Dept of Biotechnology, Srinagar, India, ${ }^{3}$ Govt PG College, Dept of Zoology, Augutmuni, India, ${ }^{4}$ All India Institute of Medical Sciences, Dept of Microbiology, Delhi, India

\section{P11 AN ULTRA-SHORT FEEDBACK LOOP FOR T3 ON THE SODIUM IODIDE SYMPORTER}

Abdulrahman $R M^{1}$, Sips $H C M^{1}$, Smit JWA ${ }^{1,2}$, Hovens GCJ'

${ }^{1}$ Leiden University Medical Center, Endocrinology, Leiden, Netherlands, ${ }^{2}$ Nijmegen University Medical Center, Internal Medicine, Nijmegen, Netherlands

\section{P12 IMPACT OF SOYBEAN ISOFLAVONES GENISTEIN AND DAIDZEIN ON SERUM LEVELS OF TSH AND T4 - EFFECTS OF AGING AND ORCHIDECTOMY}

Sosic-Jurjevic B ${ }^{1}$, Filipovic $B^{1}$, Ajdzanovic $V^{1}$, Trifunovic $S^{1}$, Nestorovic $N^{1}$, Manojlovic Stojanoski $M^{1}$, Jankovic $S^{2}$, Milosevic $V^{1}$ ${ }^{1}$ Institute for Biological Research, University of Belgrade, Belgrade, Serbia, ${ }^{2}$ Institute for Science Application in Agriculture, University of Belgrade, Belgrade, Serbia
P13 MODELING THE ABSORBED DOSE TO THE COMMON CAROTID ARTERIES FOLLOWING RADIOIODINE TREATMENT OF BENIGN THYROID DISEASE

la Cour $\mathrm{L}^{1}$, Hedemann-Jensen $\mathrm{P}^{2}$, Søgaard-Hansen $\mathrm{J}^{2}$, Nygaard $B^{3}$, Jensen $L T^{1,4}$

${ }^{1}$ Glostrup University Hospital, Department of Diagnostics, Section of Clinical Physiology, Glostrup, Denmark, ${ }^{2}$ Danish Decommissioning, Department of Radiation and Nuclear Safety, Roskilde, Denmark, ${ }^{3}$ University Hospital of Herlev, Department of Medicine, Section of Endocrinology, Herlev, Denmark, ${ }^{4}$ University Hospital of Herlev, Department of Clinical Physiology and Nuclear Medicine, Herlev, Denmark

P14 GENETIC ANALYSIS OF THE PAX8 GENE IN CHILDREN WITH CONGENITAL HYPOTHYROIDISM AND DYSGENETIC THYROID GLANDS - THE PILOT STUDY

Kumorowicz-Czoch $\mathrm{M}^{1}$, Madetko-Talowska $A^{2}$, Tylek-Lemanska $D^{3}$, Pietrzyk $J^{2}{ }^{2}$, Starzyk $J^{1}$

${ }^{1}$ Polish-American Institute of Pediatrics, Jagiellonian University Medical College, Department of Pediatric and Adolescent Endocrinology, Chair of Pediatrics, Cracow, Poland,

${ }^{2}$ Polish-American Institute of Pediatrics, Jagiellonian University Medical College, Division of Medical Genetics, Chair of Pediatrics, Cracow, Poland, ${ }^{3}$ University Children's Hospital of Cracow, Division of Mass Screening and Metabolic Diseases, Cracow, Poland

\section{P15 FUNCTIONAL LONG-TERM MAINTENANCE OF HUMAN THYROID PRIMARY CULTURES IN HUMANIZED MEDIUM (H7H)}

Garcia-Rendueles $A R^{1}$, Rodrigues JS ${ }^{1}$, Perez-Romero $S^{1}$, Suarez-Fariña $M^{1}$, Garcia-Lavandeira $M^{1}$, Rodriguez-Garcia ${ }^{2}$, Cameselle-Teijeiro J3 , Bravo SB ${ }^{4}$, Garcia-Rendueles MER ${ }^{1}$, Alvarez $\mathrm{CV}^{1}$

${ }^{1}$ University of Santiago de Compostela (USC), Centre for Medical Investigations (CIMUS), Santiago de Compostela, Spain, ${ }^{2}$ Complejo Hospitalario Universitario de Santiago de Compostela (CHUS), Clinical Biochemistry, Santiago de Compostela, Spain, ${ }^{3}$ Complejo Hospitalario Universitario de Santiago de Compostela (CHUS), Pathology, Santiago de Compostela, Spain, ${ }^{4}$ Complejo Hospitalario Universitario de Santiago de Compostela (CHUS), Instituto de Investigaciones Sanitarias (IDIS), Santiago de Compostela, Spain

\section{P16 EFFICACY OF A NEW BLOCKER AGAINST} ANTI-RUTHENIUM ANTIBODY INTERFERENCE IN THE NEW ELECSYS FT3 III AND FT4 II ASSAY

Roeddiger $R^{1}, O^{\prime}$ Mullane $J^{2}$, Stapleton $M^{2}$, Hafner $G^{3}$, O'Shea $P^{4}$, $\operatorname{Lotz} J^{5}$

${ }^{1}$ Roche Diagnostics GmbH, Clinical Operations, Mannheim, Germany, ${ }^{2}$ Cork University Hospital, Cork, Ireland, ${ }^{3}$ ZLM GmbH, Essen, Germany, ${ }^{4}$ Galway University Hospital, Galway, Ireland, ${ }^{5}$ Johannnes Gutenberg-University, Medical Center, Mainz, Germany 
P17 A NEW CLASS OF ANTITHYROID AGENT INHIBITING IODIDE TRANSPORT AND PEROXIDASE- $\mathrm{H}_{2} \mathrm{O}_{2}$ REACTION IN VITRO

Sugawara $M^{1}$

${ }^{1}$ Greater Los Angeles VA Hospital and CLA, Endocrinology and Diabetes (111M), Los Angeles, United States

\section{PO3 Thyroid Cancer Basic 1}

Chair: Rosa Marina Mellilo, Italy

\section{P18 A NOVEL ROLE FOR INTRACELLULAR} INTERLEUKIN-32 IN PROMOTING CELL DEATH BY MODULATION OF THE IL-8/FOCAL ADHESION KINASE 1 SIGNALING PATHWAY IN THYROID CANCER

Heinhuis $B^{1,2,3}$, Plantinga $T S^{1,2,3}$, Dinarello $C A^{1,2}$, Hermus $A R M^{1,3}$, Netea $M G^{1,2}$, Smit JWA ${ }^{1,3}$, Joosten $L A B^{1,2}$, Netea-Maier $R T^{1,3}$ ${ }^{1}$ Radboud University Nijmegen Medical Centre, Department of Medicine, Nijmegen, Netherlands, ${ }^{2}$ Nijmegen Institute of Infection, Immunity and Inflammation (N4i), Nijmegen, Netherlands, ${ }^{3}$ Radboud University Nijmegen Medical Centre, Division of Endocrinology, Nijmegen, Netherlands

P19 (will be presented in PO12 Basic Cancer 2 on Monday) TUMOR-EDUCATED MAST CELLS INDUCE EPITHELIALTO-MESENCHYMAL TRANSITION AND EXPANSION OF STEM CELL POPULATION VIA IL-8/CXCR1/CXCR2 AXIS IN THYROID CANCER.

Visciano $C^{1}$, Liotti $F^{1}$, Prevete $N^{2}$, Cali $G^{3}$, de Paulis $A^{2}$, Marone $G^{2}$, Santoro $\mathrm{M}^{1,3}$, Melillo $\mathrm{RM}^{1,3}$

${ }^{1}$ Universita di Napoli Federico II, Dipartimento di Medicina Molecolare e Biotecnologie Mediche, Naples, Italy, ${ }^{2}$ Universita di Napoli Federico II, Dipartimento di Scienze Mediche Traslazionali e Centro Interdipartimentale di Ricerca in Scienze Immunologiche di Base e Cliniche, Naples, Italy, ${ }^{3}$ Universita di Napoli Federico II, Istituto per L'Endocrinologia e I'Oncologia Molecolare del CNR, Naples, Italy

\section{P20 MIGRATION AND REDUCED APOPTOSIS IN} FOLLICULAR THYROID CARCINOMAS AS AN EFFECT OF DIFFERENTIAL MIRNA EXPRESSION

Wojtas $B^{1}$, Ferraz $C^{2}$, Stokowy $T^{1,3}$, Jarzab $B^{1}$, Paschke $R^{2}$, Eszlinger $\mathrm{M}^{2}$

${ }^{1}$ MSC Memorial Cancer Center and Institute of Oncology Gliwice Branch, Department of Nuclear Medicine and Endocrine Oncology, Gliwice, Poland, 2University of Leipzig, Division of Endocrinology and Nephrology, Leipzig, Germany, ${ }^{3}$ Silesian University of Technology, Institute of Automatic Control, Gliwice, Poland
P21 CELL CYCLE TARGETING IN CELLS CARRYING P53 POINT MUTATIONS: A NOVEL PERSPECTIVE FOR UNDIFFERENTIATED THYROID CANCER THERAPY Grassi ES ${ }^{1}$, Vezzoli $V^{1}$, Negri ${ }^{2}$, Persani $L^{1,3}$

${ }^{1}$ University of Milan, Clinical Sciences \& Community Health, Milan, Italy, ${ }^{2}$ University of Milan, Milan, Italy, ${ }^{3}$ IRCCS Istituto Auxologico Italiano, Division of Endocrine and Metabolic Diseases \& Lab. of Endocrine and Metabolic Research, Milan, Italy

\section{P22 NUCLEAR CYSTEINE CATHEPSIN VARIANTS IN} THYROID CANCER

Tedelind $S^{1}$, Perera $R^{1}$, Yurtdas $Y^{1}$, Pinzaru $A^{1}$, Szumska J', Burden $R^{2}$, Rehders $M^{1}$, Scott $C^{2}$, Führer $D^{3}, \underline{B r i x} K^{1}$

${ }^{1}$ Jacobs University Bremen, School of Engineering and Science, Bremen, Germany, ${ }^{2}$ Queen's University of Belfast, School of Pharmacy, Belfast, United Kingdom,

${ }^{3}$ Universitätsklinikum Essen, Klinik für Endokrinologie und

Stoffwechselerkrankungen, Essen, Germany

\section{P23 IMPACT OF CLAUDIN-1 ON EPITHELIAL-} MESENCHYMAL TRANSITION IN PAPILLARY THYROID CARCINOMA

Zwanziger $D^{1}$, Amborska $R^{1}$, Jaeger $A^{1}$, Führer $D^{1}$

${ }^{1}$ University Hospital Essen, Essen, Germany

\section{P24 MIRNAS WITH THE POTENTIAL TO DISTINGUISH FOLLICULAR THYROID CARCINOMAS FROM BENIGN FOLLICULAR THYROID TUMORS - RESULTS OF A META ANALYSIS}

Stokowy $T^{1,2}$, Wojtaś $B^{1}$, Fujarewicz $K^{2}$, Jarząb $B^{1}$, Eszlinger $M^{3}$ Paschke $R^{3}$

${ }^{1}$ Maria Sklodowska-Curie Memorial Cancer Center and Institute of Oncology, Nuclear Medicine and Endocrine Oncology Department, Gliwice, Poland, ${ }^{2}$ Silesian University of Technology, Gliwice, Poland, ${ }^{3}$ University of Leipzig, Division of Endocrinology and Nephrology, Germany

\section{P25 CYTOLOGY OF LYMPHOMAS IN THE THYROID GLAND}

Vasilj ${ }^{1}$, Kojic Katovic $S^{1}$, Curic-Juric $S^{1}$, Maricevic I' , Sokcevic M' Zokvic $E^{1}$

'University Hospital Center 'Sestre milosrdnice', Department of Cytology, Zagreb, Croatia

\section{P26 THE CLINICAL SIGNIFICANCE OF TUMOR} SUPPRESSOR GENE METHYLATION - EXPRESSION IN NODULAR THYROID DISEASE

Wei $F^{1}$, Wang $Z^{1}$, Wu $Y^{1,2}, L i Y^{1}, Y u Y^{1}$

${ }^{1}$ The First Affiliated Hospital, Bao Tou Medical College, Inner Mongol ia Science \& Technology University, Department of Endocrinology, Bao Tou, China, ${ }^{2}$ The First Hospital, Bao Tou Medical College, Inner Mongolia University of Science and Technology, Endocrinology Department, Baotou, China 
P27 MULTICENTER EVALUATION OF A HIGHLY SENSITIVE THYROGLOBULIN IMMUNOASSAY ON ELECSYS SYSTEMS Roeddiger $R^{1}$, Hafner $G^{2}$, Keller $F^{3}$, d'Herbomez $M^{4}$, Kratzsch $J^{5}$ ${ }^{1}$ Roche Diagnostics $\mathrm{GmbH}$, Clinical Operations, Mannheim, Germany, ${ }^{2}$ ZLM GmbH, Essen, Germany, ${ }^{3}$ EOLAB, Lugano, Switzerland, ${ }^{4} \mathrm{CHRU}$, Lille, France, ${ }^{5}$ University Leipzig, Leipzig, Germany

\section{P28 DESCRIPTION OF A NEW HIGHLY SENSITIVE} THYREOGLOBULIN IMMUNOASSAY: THERMO SCIENTIFIC B·R・A.H·M.S HTG SENSITIVE KRYPTOR

Theimer $C^{1}$, Thomas $E^{2}$, Algeciras-Schimnich $A^{3}$, Preissner $C^{3}$ ${ }^{1}$ Thermo Fisher Scientific, Hennigsdorf, Germany, ${ }^{2}$ Thermo Fisher Scientific, Nîmes, France, ${ }^{3}$ MAYO Clinic, Rochester, United States

\section{P29 PARANEOPLASTIC LEUKOCYTOSIS - POSSIBLE} SYMPTOM OF THYROID CANCER PROGRESSION?

Krajewska J' , Olczyk $T^{1}$, Paliczka-Cieslik $E^{1}$, Kalemba $M^{1}$, Jarzab $B^{1}$ ${ }^{1}$ Maria Sklodowska-Curie Memorial Cancer Center and Institute of Oncology, Nuclear Medicine and Endocrine Oncology Department, Gliwice, Poland

\section{P04 Thyroid Cancer Diagnostics 1 \\ Chair: Sophie Leboulleux, France}

\section{P30 MALIGNANCY RATE OF THYROID NODULES} DETECTED BY HEALTH EXAMINATION WAS ASSOCIATED WITH PATIENTS' AGE AND NODULE SIZE IN PATIENTS AGED 60 YEARS OR OLDER

Choi $H^{1}$, Roh $E^{1}$, Hwang Bo $Y^{1}$, Kang $\mathrm{SM}^{2}$, Choi SI ${ }^{2}$, Moon $\mathrm{JH}^{2}$,

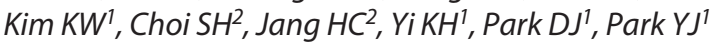
${ }^{1}$ Seoul National University Hospital, Internal Medicine, Seoul, Korea, Republic of, ${ }^{2}$ Seoul National University Bundang Hospital, Internal Medicine, Seongnam-Si, Republic of Korea

\section{P31 TGAB POSITIVE (+) PAPILLARY THYROID CANCER} (PTC) PATIENTS WITH LYMPHOCYTIC THYROIDITIS (LT) DETECTED AT THYROIDECTOMY (TX) SUGGESTS AN INCREASED RISK OF RECURRENCE (R) DURING FOLLOW-UP (F/U)

Fatemi $S^{1}$, LoPresti $\mathcal{J}^{2}$, Singer $P^{2}$, Spencer $C^{2}$

${ }^{1}$ Southern California Permanente Medical Group, Endocrinology, Panorama City, United States, ${ }^{2}$ University of Southern California/Keck School of Medicine, Medicine, Los Angeles, United States
P32 EVALUATION OF A NEW ULTRASENSITIVE THYROGLOBULIN ASSAY IN THE FOLLOW-UP OF PATIENTS WITH DIFFERENTIATED THYROID CANCER

Accornero $S^{1}$, Pignatti $P^{2}$, Coperchini $F^{1}$, Testoni $C^{2}$, Theimer $C^{3}$, Chiovato $L^{1}$

${ }^{1}$ Fondazione Salvatore Maugeri - IRCCS, Internal Medicine and Endocrinology Unit, Pavia, Italy, ${ }^{2}$ Fondazione Salvatore Maugeri - IRCCS, Allergy and Immunology Unit, Pavia, Italy, ${ }^{3}$ Thermo Scientific Biomarkers, Hennigsdorf, Germany

\section{P33 RECOMBINANT HUMAN THYROTROPIN} STIMULATION THYROGLOBULIN (RHTSH-TG) TEST CAN IDENTIFY FALSE SERUM TG DUE TO HETEROPHILIC ANTIBODIES IN DIFFERENTIATED THYROID CANCER (DTC) PATIENTS

Matrone $A^{1}$, Gambale $C^{1}$, Taddei $D^{1}$, Nencetti $C^{1}$, Molinaro $E^{1}$, Agate $L^{1}$, Bottici $V^{1}$, Viola $D^{1}$, Vitti $P^{1}$, Elisei $R^{1}$

${ }^{1}$ University of Pisa, Endocrine Unit - Department of Clinical and Experimental Medicine, Pisa, Italy

\section{P34 SURGEON-PERFORMED ULTRASOUND-GUIDED FINE-NEEDLE ASPIRATION CYTOLOGY SHORTENS TIME FOR DIAGNOSIS OF THYROID NODULES}

Gu $W^{1}$, Tan $\mathrm{CS}^{2}$, Ho TWT $T^{3}$

${ }^{1}$ National University of Singapore, Yong Loo Lin School of Medicine, Singapore, Singapore, ${ }^{2}$ National University of Singapore, Saw Swee Hock School of Public Health, Singapore, Singapore, ${ }^{3}$ Tan Tock Seng Hospital, Section of Head and Neck Surgery, Department of General Surgery, Singapore, Singapore

\section{P35 CYSTIC CHANGE AFTER FINE NEEDLE ASPIRATION} BIOPSY OF CIRCUMSCRIBED SOLID THYROID NODULES WITHOUT MALIGNANT US FEATURES: IS IT MEANINGFUL? Rhee $\mathrm{SJ}^{1,2}$, Shin $\mathrm{JH}^{1}$, Han B-K$K^{1}, K_{0} E Y^{1}, K_{0} E S^{1}$, Hahn $S Y^{1}$ ${ }^{1}$ Samsung Medical Center, Radiology, Seoul, Republic of Korea, ${ }^{2}$ Kyung Hee University Hospital at Gangdong, Radiology, Seoul, Republic of Korea

P36 FINE-NEEDLE ASPIRATION (FNA) OF THYROID NODULES GUIDED BY ULTRASONOGRAPHY. VALUE TIRADS Jiménez $M^{1,2}$, Gayoso $R^{2}$, Sapunar $J^{1,2}$, Granzotto $C^{1}$, Roa $J C^{1,2}$, Huenchullan $C^{1}$, Ortiz $E^{1,2}$

${ }^{1}$ Clinica Alemana Temuco, Unidad Endocrinología y Diabetes, Temuco, Chile, ${ }^{2}$ Temuco German Clinic, Faculty of Medicine University of La Frontera to Temuco, Temuco, Chile

\section{P37 ROLE OF ELASTOGRAPHY IN DIAGNOSIS OF SUSPECIOUS THYROID NODULES \\ Abo Elwafa WAH \\ ${ }^{1}$ Faculty of Medicine, Alexandria University, Department of Surgery, Alexandria, Egypt}

P38 THYROID NODULES IN MADEIRA ISLAND, PORTUGAL - A RETROSPECTIVE STUDY

Resende $E^{1}$, Ferreira $M^{1}$, Sá $M^{1}$, Abreu $S^{1}$

${ }^{1}$ Hospital Central do Funchal, Endocrinology, Funchal, Portugal 
P05 Thyroid Cancer Pathogenesis

Chair: Cristina Romei, Italy

P39 CLINICAL IMPLICATION OF BRAFV600E MUTATION IN PAPILLARY THYROID CARCINOMA

Kim YS ${ }^{1}$, Park WC ${ }^{2}$, Kim JS 1

${ }^{1}$ College of Medicine, The Catholic University of Korea, Department of Surgery, Uijeongbu-si, Republic of Korea, ${ }^{2}$ College of Medicine, The Catholic University of Korea, Department of Surgery, Seoul, Republic of Korea

P40 HURHTLE CELL THYROID CARCINOMA: A MULTICENTRIC RETROSPECTIVE STUDY WITH MIRNA PROFILING

Bonichon $F^{1}$, Do Cao $C^{2}$, Guyetant $S^{3}$, Schvartz $C^{4}$, Soubeyran $I^{5}$, Rohmer $V^{6}$, Toubeau $M^{7}$, Savagner $F^{8,9}$

${ }^{1}$ Institut Bergonie, Bordeaux, France, ${ }^{2}$ Endocrinologie, Lille, France, ${ }^{3}$ Laboratoire d'anatomopathologie, Tours, France, ${ }^{4}$ Laboratoire d'anatomopathologie, Dijon, France, ${ }^{5}$ Laboratoire d'anatomopathologie, Bordeaux, France, ${ }^{6}$ Endocrinologie, Angers, France, ${ }^{7}$ Medecine Nucleaire, Dijon, France, ${ }^{8}$ Laboratoire de Genetique molecuaire, Angers, France, ${ }^{9} \mathrm{EA} 3143$, Angers, France

\section{P41 ASSOCIATION BETWEEN CYP2E1 PROMOTER POLYMORPHISMS AND PAPILLARY THYROID CANCER WITH EXTRATHYROIDAL EXTENSION IN KOREAN POPULATION}

Kim D-Y ${ }^{1}$, Hong IK ${ }^{1}$, Kim SK ${ }^{2}$, Chung $J-H^{2}$

${ }^{1}$ Kyung Hee University Hospital, Nuclear Medicine, Seoul, Republic of Korea, ${ }^{2}$ Kohwang Medical Research Institute, Kyung Hee University, Seoul, Republic of Korea

\section{P42 BRAF $^{\text {V600E }}$ MUTATIONAL STATUS AND ITS CLINICAL SIGNIFICANCE IN MULTIFOCAL PAPILLARY THYROID CARCINOMA OF THE KOREAN POPULATION \\ Ahn $\mathrm{HY}^{1}$, Chung $\mathrm{YJ}^{1}$, Kang $\mathrm{KH}^{2}$, Park $S \mathrm{~J}^{2}$, Cho $B Y^{1}$ \\ ${ }^{1}$ Chung-Ang University Hospital, Internal Medicine, Seoul, Korea, Republic of, ${ }^{2}$ Chung-Ang University Hospital, Surgery, Seoul, Republic of Korea}

P43 DETAILS OF HISTOPATHOLOGY IN PATIENTS WITH ONE OR MORE FIRST DEGREE RELATIVE WHO HAVE WELL DIFFERENTIATED THYROID CANCER (WDTC)

Frangos $S^{1}$, Vanezi $A^{1}$, Savva $A^{1}$, Rousounidou $A^{1}$, Patsali $L^{1}$

${ }^{1}$ Bank of Cyprus Oncology Center, Nuclear Medicine, Strovolos, Nicosia, Cyprus

\section{P44 CLINICOPATHOLOGICAL SIGNIFICANCE OF CARCINOMA ASSOCIATED FIBROBLASTS (CAF) IN PAPILLARY THYROID CARCINOMA: THE PREDICTIVE MAKER OF CERVICAL LYMPH NODE METASTASES}

Cho J-G ${ }^{1}$, Park $M-W^{1}$, Baek S-K $K^{1}, K$ won S- $Y^{1}$, Jung $K-Y^{1}$, Woo J-S $S^{1}$

${ }^{1}$ Korea University Medical College, Otorhinolaryngology-Head and Neck Surgery, Seoul, Republic of Korea
P45 ISTHMIC LOCATION OF MALIGNANT THYROID NODULES REPRESENTS AN ADDITIONAL RISK FACTOR FOR METASTATIC DISEASE IN PATIENTS AFFECTED BY LOW RISK DIFFERENTIATED THYROID CANCER (DTC).

Ruggeri RM ${ }^{1}$, Cucinotta $M^{2}$, Giovinazzo $S^{1}$, Quartuccio $N^{2}$, Stipo $M^{2}{ }^{2}$, Baldari $S^{2}$, Trimarchi $F^{1}$, Campennì $A^{2}$

${ }^{1}$ University of Messina, Dep of Clinical and Experimental Medicine, Messina, Italy, ${ }^{2}$ University of Messina, Unit of Nuclear Medicine, Messina, Italy

P46 THYROID CANCER AFTER IN VITRO FERTILIZATION: A RETROSPECTIVE, NON-CONSECUTIVE CASE-SERIES ANALYSIS

Pazaitou-Panayiotou $K^{1}$, Toulis $K A^{1,2}$, Mandanas $S^{1}$, Tarlatzis $B C^{2}$

${ }^{1}$ Theagenio Cancer Hospital, Dept. of Endocrinology-Endocrine Oncology, Thessaloniki, Greece, ${ }^{2}$ Unit for Human

Reproduction, First Department of Obstetrics and Gynaecology, Aristotle University of Thessaloniki, Thessaloniki, Greece

P47 SYNCHRONOUS MICROPAPILLARY THYROID CARCINOMA AND NON HYPERCALCEMIC PARATHYROID CARCINOMA: A CASE REPORT

Ramos $\mathrm{CO}^{1}$, Aquino $\mathrm{E}^{1}$

${ }^{1}$ St. Luke's Medical Center, Endocrinology and Metabolism, Quezon City, Philippines

P06 Thyroid Cancer Therapeutics 1

Chair: Christine Spitzweg, Munich

P48 RETROAURICULAR ROBOTIC THYROIDECTOMY WITH OR WITHOUT MODIFIED RADICAL NECK DISSECTION Koh YW' ${ }^{1}$, Baek SJ', Bong JP', Hong HJ ${ }^{1}$, Kim JW' ${ }^{2}$, Kim W-S ${ }^{1}$, Kwon $\mathrm{JH}^{1}$, Park $\mathrm{JH}^{3}$, Lee $\mathrm{HJ}^{1}$, Ahn $\mathrm{SH}^{1}$, Choi EC ${ }^{1}$

${ }^{1}$ Yonsei University College of Medicine, Otorhinolaryngology, Seoul, Korea, Republic of, ${ }^{2}$ Soonchunhyang University Hospital, Otolaryngology-Head and Neck Surgery, Seoul, Republic of Korea, ${ }^{3}$ Soonchunhyang University Hospital, OtolaryngologyHead and Neck Surgery, Cheonan, Republic of Korea

\section{P49 COMPARISON BETWEEN SPORADIC AND FAMILIAL PAPILLARY THYROID MICROCARCINOMA}

Busonero $G^{1}$, Capezzone $M^{1}$, Forleo $R^{1}$, Durante $C^{2}$, Filetti $S^{2}$, Pazaitou-Panayiotou $K^{3}$, Pacini $F^{1}$

${ }^{1}$ University of Siena, Section of Endocrinology, Department of Medical, Surgical and Neurological Sciences, Siena, Italy, ${ }^{2}$ University of Rome La Sapienza, Department of Clinical Sciences, Rome, Italy, ${ }^{3}$ University of Thessaloniki, Department of Endocrinology-Endocrine Oncology, Thessaloniki, Greece 
P50 A COMPARISON OF CLINICAL EFFECTIVENESS OF LOW VERSUS HIGH DOSE RADIOABLATION IN DIFFERENTIATED THYROID CANCER PATIENTS Urhan $M^{1}$, San $H^{1}$, Yucel $E^{2}$, Cagıltay $E^{3}$, Ozsari $L^{3}$, Yonem $A^{3}$ ${ }_{1}^{1 G A T A}$ Haydarpasa Training Hospital, Nuclear Medicine, Istanbul, Turkey, ${ }^{2}$ GATA Haydarpasa Training Hospital, Surgery, Istanbul, Turkey, ${ }^{3}$ GATA Haydarpasa Training Hospital, Endocrinology and Metabolism, Istanbul, Turkey

\section{P51 LOW-RISK PAPILLARY THYROID CARCINOMA:}

\section{TO ABLATE OR NOT TO ABLATE}

Azevedo $T C^{1}$, Rodrigues $\mathrm{FJ}^{1}$, Martins $T \mathrm{M}^{1}{ }^{1}$, Neto $\mathrm{J}^{2}$, Rovira $E^{2}$, Lemos $M^{1,3}$, Martinho $M^{1,4}$, Oliveira $S^{2}$

${ }^{1}$ Instituto Português de Oncologia de Coimbra, Serviço de Endocrinologia, Coimbra, Portugal, ${ }^{2}$ Instituto Português de Oncologia de Coimbra, Serviço de Medicina Nuclear, Coimbra, Portugal, ${ }^{3}$ Universidade da Beira Interior, Centro de Investigação em Ciências da Saúde (CICS), Covilhã, Portugal, ${ }^{4}$ Centro Hospitalar do Tâmega e Sousa, Penafiel, Portugal

\section{P52 IS THE DISSECTION OF RIGHT SIDE SUPERIOR} MEDIASTINAL LYMPH NODES IS NECESSARY DURING OPERATION FOR PAPILLARY THYROID CANCER?

OhEM ${ }^{1}$, Cheung $Y S^{1}$, Song $W^{1}{ }^{1}$, Lee $Y D^{1}$

${ }^{1}$ Gachon Gil University Hospital, Thyroid Clinic, General Surgery, Incheon, Republic of Korea

\section{P53 LIGASURE VS. HARMONIC SCALPEL IN TOTAL THYROIDECTOMY: COMPARING OUTCOMES AND COMPLICATIONS \\ Byon $W^{1}$, Hyun $K^{1}$, Yun J-S ${ }^{1}$, Park $Y L^{1}$, Park $C H^{1}$ \\ ${ }^{1}$ Kangbuk Samsung Hospital, Sungkyunkwan University School of Medicine, Department of Surgery \& Breast-Thyroid Cancer \\ Center, Seoul, Republic of Korea}

\section{P54 SURVIVAL RATES AND PROGNOSTIC FEATURES OF} 1167 PAPILLARY THYROID CARCINOMA PATIENTS WITH LONG-TERM FOLLOW-UP

Jukić $T^{1}$, Franceschi $M^{1}$, Lukinac $L^{1}$, Granić $R^{1}$, Staničić $J^{1}$, Šiško Markoš ${ }^{1}$, Punda $M^{1}$, Dabelić $N^{1}$, Mateša $N^{1}$, Sonicki $Z^{2}$, Kusić $Z^{1}$

'University Hospital Center 'Sestre milosrdnice', Department of Oncology and Nuclear Medicine, Zagreb, Croatia, ${ }^{2}$ School of Public Health 'Andrija Štampar', Zagreb, Croatia

\section{P55 OUTCOMES FOR DIFFERENTIATED THYROID CANCER (DTC) ARISING IN PATIENTS WITH A PRIOR PAEDIATRIC MALIGNANCY \\ Mulholland $L E^{1,2}$, Newbold $K^{1}$ \\ ${ }^{1}$ Royal Marsden Hospital, Thyroid Unit, Sutton, United Kingdom, ${ }^{2}$ Northern Ireland Cancer Centre, Clinical Oncology, Belfast, United Kingdom}

P56 TYROSINE KINASE INHIBITORS FOR THE TREATMENT OF REFRACTORY THYROID CANCER: BALANCING EFFICACY AND QUALITY OF LIFE

Chrisoulidou $A^{1}$, Mathiopoulou L' ${ }^{1}$, Mandanas $S^{1}$, Boudina $M^{1}$,

Pazaitou-Panayiotou $K^{1}$

${ }^{1}$ Theagenio Cancer Hospital, Dept. of Endocrinology-Endocrine Oncology, Thessaloniki, Greece

P07 Case Reports 1

Chair: Istvàn Szabolcs, Hungary

P57 INDICATIONS FOR THE GASLESS TRANSAXILLARY ROBOTIC APPROACH TO THYROID SURGERY - EXPERIENCE OF 100 PROCEDURES AT THE AMERICAN HOSPITAL OF PARIS

Aidan $\mathrm{P}^{1}$, Boccara $\mathrm{G}^{2}$, Monpeyssen $\mathrm{H}^{3}$, Beressi $\mathrm{N}^{4}$

${ }^{1}$ American Hospital of Paris, ENT department, Neuilly sur Seine, France, ${ }^{2}$ American Hospital of Paris, Anestesist, Neuilly sur Seine, France, ${ }^{3}$ American Hospital of Paris, Radiology, Neuilly sur Seine, France, ${ }^{4}$ American Hospital of Paris, Endocrinology, Neuilly sur Seine, France

P58 CLINICAL CHARACTERISTICS OF ESOPHAGEAL DIVERTICULA MISDIAGNOSED AS THYROID NODULE Lee $D C^{1}, K_{i m} T H^{1}, K_{i m} H W^{1}$, Jo $S K^{1}$, Jung $S W^{1}$, Lee $S J^{1}, K i m S H^{1}$, Lim $J K^{1}$

${ }^{1}$ Kwangju Christian Hospital, Endocrinology, Gwangju, Republic of Korea

P59 HYALINISING TRABECULAR TUMOUR IN ADENOMATOID GOITER - A CASE OF 59-YEAR-OLD MAN WITH HIV DISEASE

Petranović Ovčariček $P^{1}$, Jukić $T^{1}$, Franceschi $M^{1}$, Čupić $H^{2}$, Kusić $Z^{1}$ 'University Hospital Center 'Sestre milosrdnice', Department of Oncology and Nuclear Medicine, Zagreb, Croatia, ${ }^{2}$ University Hospital Center 'Sestre milosrdnice', Department of Pathology 'Ljudevit Jurak', Zagreb, Croatia

\section{P60 THE SCLEROTHERAPY WITH ETHANOL - AN} UNCOMMON, BUT SUCCESSFUL METHOD OF TREATMENT OF A HUGE BRANCHIAL CLEFT CYST

Raykov $\mathrm{NI}^{1}$, Vicheva $\mathrm{S}^{2}$, Raykova $\mathrm{AN}^{3}$

1'Varna ' Hospital, Department of Internal Diseases, Varna, Bulgaria, ${ }^{2}$ Oncological Dispensary 'Marko Markov', Department of Clinical Pathology, Varna, Bulgaria, ${ }^{3}$ MU-Pleven, Pleven, Bulgaria

\section{P61 PAPILLARY THYROID CARCINOMA WITH} LYMPHOCYTIC THYROIDITIS IN AN AUTONOMOUS HYPERFUNCTIONING THYROID NODULE

Calimon MAP ${ }^{1}$, Lim Uy SW ${ }^{1}$

${ }^{1}$ St. Luke's Medical Center, Section of Endocrinology, Diabetes and Metabolism, Quezon City, Philippines 
P62 10.000KM ON BICYCLE UNDER TYROSINE KINASE INHIBITOR THERAPY WITH VANDETANIB

Weidner $S^{1}$, Klaeser $B^{1}$, Wartenberg $J^{1}$, Krause $T^{1}$

${ }^{1}$ Inselspital, University Hospital of Berne, Berne, Switzerland

P63 CONTEMPORANEOUS OCCURRENCE OF THYROGLOSSAL DUCT CYST AND LINGUAL THYROID IN THE ABSENCE OF AN ORTHOTOPIC THYROID GLAND CASE REPORT

Kim SW' ${ }^{1}$, Park $I S^{2}$

${ }^{1}$ VHS Medical Center, Department of Otolaryngology-Head and Neck Surgery, Seoul, Korea, Republic of, ${ }^{2}$ Dongtan Sacred Heart Hospital Hallym University, Department of Otolaryngology-Head and Neck Surgery, Dongtan, Republic of Korea

\section{P64 TUBERCULOUS ABSCESS OF THE THYROID GLAND} Gapuz $K T^{1}$, Esposo $E A^{1}$

${ }^{1}$ St. Luke's Medical Center-Quezon City, Department of Medicine, Quezon City, Philippines

\section{P65 MULTIPLE TREATMENT OF PATIENTS WITH BONE METASTASES FROM DIFFERENTIATED THYROID CARCINOMA}

Gerqari I ${ }^{1}$, Rizvanolli $N^{2}$, Miftari $R^{1}$, Bajrami I ${ }^{1}$, Bajqinca $A^{1}$, Spahiu $F^{1}$

${ }^{1}$ University Clinical Center of Kosovo, Nuclear Medicine Service, Pristina, Albania, ${ }^{2}$ Diagnostika plus, Pristina, Albania

\section{P08 Clinical Thyroidology 1 \\ Chair: Murat Erdogan, Turkey}

\section{P66 LOW NORMAL FREE T4 CONFERS DECREASED HIGH} DENSITY LIPOPROTEIN ANTI-OXIDATIVE FUNCTIONALITY IN THE CONTEXT OF HYPERGLYCEMIA

Dullaart $R P^{1}$, Triolo $M^{1}$, Kwakernaak $A^{2}$, Annema $W^{2}$, Tietge $U J^{3}$

${ }^{1}$ University of Groningen, Endocrinology, Groningen, Netherlands, ${ }^{2}$ University of Groningen, Groningen, Netherlands, ${ }^{3}$ University of Groningen, Center for Liver, Digestive and Metabolic Diseases, Groningen, Netherlands

\section{P67 THE VALUE OF RED BLOOD CELL DISTRIBUTION} WIDTH IN THE SUBCLINICAL HYPOTHYROIDISM

Yu $H M^{1}$, Park KS $S^{1}$, Lee $J M^{1}$, Ryu $A J^{1}$

${ }^{1}$ Research Institute of Clinical Medicine, Eulji University Hospital, Division of Endocrinology and Metabolism, Department of Internal Medicine, Daejeon, Republic of Korea
P68 MYOCARDIAL DIASTOLIC FUNCTION IN PATIENTS WITH AUTOIMMUNE THYROIDITIS AND TSH VALUES WITHIN THE REFERENCE OR SUBCLINICAL RANGE: RELATIONSHIP TO THYROID AND METABOLIC INDICES Strongin $L G^{1}$, Nekrasova $T A^{1}$, Ledentsova OV ${ }^{2}$, Kasakova $L V^{3}$, Lukushkina $A Y^{1}$

${ }^{1}$ Nizhny Novgorod State Medical Academy, Endocrinology, Nizhny Novgorod, Russian Federation, ${ }^{2}$ Nizhny Novgorod Regional Diagnostic Center, Endocrinology, Nizhny Novgorod, Russian Federation, ${ }^{3}$ Volga Region Medical Center of MBA, Internal Medicine, Nizhny Novgorod, Russian Federation

P69 ATHEROGENIC LIPOPROTEINS IN SUBCLINICAL HYPOTHYROIDISM AND THEIR RELATIONSHIP WITH HEPATIC LIPASE ACTIVITY. RESPONSE TO REPLACEMENT TREATMENT WITH LEVOTHYROXINE

Brenta $G^{1}$, Berg $G^{2}$, Miksztowicz $V^{2}$, Lopez $G^{2}$, Lucero $D^{2}$, Faingold $C^{1}$, Nakajima $K^{2,3}$, Schreier $L^{2}$

${ }^{1}$ Cesar Milstein Hospital, Endocrinology, Buenos Aires, Argentina, ${ }^{2}$ Faculty of Pharmacy and Biochemistry, University of Buenos Aires, Lipids and Lipoprotein Laboratory, Buenos Aires, Argentina, ${ }^{3}$ Graduate School of Health Sciences, Gunma University, Gunma, Japan

\section{P70 AUTOIMMUNE THYROIDITIS: ADIPOKINES AND CARDIOVASCULAR RISK FACTORS IN SUBCLINICAL HYPOTHYROIDISM}

Neves $C^{1}$, Esteves $C^{1}$, Pereira $M^{1}$, Dias $C^{2}$, Palmares $C^{3}$, Sokhatska $O^{3}$, Carvalho $D^{1}$, Delgado $L^{3}$, Medina $J^{1}$

${ }^{1}$ São João Hospital, Faculty of Medicine, University of Porto, Department of Endocrinology, Diabetes and Metabolism, Porto, Portugal, '2São João Hospital, Faculty of Medicine, University of Porto, Department of Biostatistics and Medical Informatics, Porto, Portugal, ${ }^{3}$ São João Hospital, Faculty of Medicine, University of Porto, Department of Immunology, Porto, Portugal

P71 LOW T3 CONCENTRATIONS AT THE BEGINNING OF HEMODIALYSIS TREATMENT ARE ASSOCIATED WITH A HIGH MORTALITY RATE IN PATIENTS WITH CHRONIC KIDNEY DISEASE (CKD)

Reinhardt $W^{1}$, Dolff $S^{1}$, Broecker-Preuss $M^{2}$, Führer $D^{2}$, Witzke $O^{1}$

${ }^{1}$ University of Duisburg-Essen, Clinic of Nephrology, Essen, Germany, ${ }^{2}$ University of Duisburg-Essen, Clinic of Endocrinology and Metabolism, Essen, Germany

\section{P72 SUBCLINICAL HYPOTHYROIDISM, SPONTANEOUS EVOLUTION IN AN URBAN POPULATION OF THE MEDITERRANEAN COAST}

Tortosa $F^{1}$, Ossó $J^{2}$, Gomez Ramirez $M^{2}$, Sanchez $A^{3}$, Aldea $M^{4}$, Mesa J', Lecube $A^{1}$

${ }^{1}$ Hospital de la Vall d'Hebron, Endocrinology and Nutrition, Barcelona, Spain, 2EAP St Andreu, Family Medicine, Barcelona, Spain, ${ }^{3}$ Ambit Barcelona. ICS, Barcelona, Spain, ${ }^{4}$ Hospital Clinic i Provincial, Preventive Medicine, Barcelona, Spain 
P73 THE EFFECT OF IODINE RESTRICTION ON THYROID FUNCTION IN SUBCLINICAL HYPOTHYROIDISM PATIENTS Sohn SY ${ }^{1}$, Joung $\mathrm{JY}^{1}$, Cho $Y Y^{1}$, Kim NK ${ }^{1}, \mathrm{Kim} \mathrm{SW}^{1}$, Chung $\mathrm{JH}^{1}$ ${ }^{1}$ Samsung Medical Center, Sungkyunkwan University School of Medicine, Division of Endocrinology \& Metabolism, Department of Medicine, Seoul, Republic of Korea

\section{P74 FUNCTIONAL GASTROINTESTINAL DISORDERS IN} CHILDREN WITH GOITER

Bugayenko OA ${ }^{1}$, Mamenko MY $^{1}$, Belykh NA ${ }^{1}$, Yerokhina $\mathrm{OI}^{1}$, Budnik TV

${ }^{1}$ Luhansk State Medical University, Department of

Postgraduate Education in Pediatrics, Luhansk, Ukraine

\section{P75 PANCYTOPENIA RELATED TO AMIODARONE INDUCED HYPOTHYROIDISM: CASE REPORT}

Resende $E^{1}$, Ferreira $M^{2}$, Sá $M^{2}$, Abreu $S^{2}$

${ }^{1}$ Hospital Central do Funchal, Funchal, Portugal, ${ }^{2}$ Hospital Central do Funchal, Endocrinology, Funchal, Portugal

\section{P76 GRAVES DISEASE AND MEMBRANOUS} GLOMERULONEPHRITIS

Stojkovic $M^{1}$, Beleslin $B^{1}$, Ciric J $J^{1}$, Savic $S^{1}$, Simic $S^{2}$, Nisic $T^{1}$, Lalic $T^{1}$, Stojanovic $M^{1}$, Trbojevic $B^{1}$, Zarkovic $M^{1}$

${ }^{1}$ Clinic of Endocrinology, Diabetes and Metabolism, Clinical Center of Serbia, Belgrade, Serbia, ${ }^{2}$ Clinic of Nephrology,

Clinical Center of Serbia, Belgrade, Serbia

\section{P09 Graves' Orbitopathy}

Chair: Anja Eckstein, Germany

\section{P77 INTRANASAL MEDIAL ENDOSCOPIC}

DECOMPRESSION (IMED) AS AN EFFICIENT TREATMENT FOR PATIENTS WITH DYSTHYROID OPTIC NEUROPATHY (DON)

Miśkiewicz $P^{1}$, Trautsolt $K^{1}$, Pirko-Kotela $K^{1}$, Jabłońska $A^{2}$, Samsel $A^{2}$, Wołczańska $N^{1}$, Milczarek-Banach J ${ }^{1}$, Kęcik $D^{2}$, Krzeski $A^{3}$, Bednarczuk $T^{1}$

${ }^{1}$ Medical University of Warsaw, Department of Endocrinology and Internal Medicine, Warsaw, Poland, ${ }^{2}$ Medical University of Warsaw, Department of Ophthalmology, Warsaw, Poland, ${ }^{3}$ Medical University of Warsaw, Department of Otolaryngology, Division of Dentistry, First Faculty of Medicine, Warsaw, Poland

\section{P78 SOME ASPECTS OF TREATMENT OF THE DRY EYE SYNDROME CAUSED BY OF ENDOCRINE OPHTHALMOPATHY}

Papava $M^{1}$, Javashvili $L^{2}$, Dundua $T^{2}$, Gaprindashvili $N^{3}$

${ }^{1}$ Research Institute of Clinical Medicine, Tbilisi, Georgia, ${ }^{2} \mathrm{Clinic}$ Cortex, Tbilisi, Georgia, ${ }^{3}$ Medical Center Neoclinic, Tbilisi, Georgia
P79 THE ROLE OF THYROTROPIN RECEPTOR ANTIBODIES IN GRAVE'S OPHTHALMOPATHY ACTIVITY AND RESPONSE TO TREATMENT

Petunina NA ${ }^{1}$, Martirosian $N^{1}$, Trukhina LV ${ }^{1}$, Saakyan SV², Panteleeva $\mathrm{OG}^{2}$, Sirmays $\mathrm{OS}^{2}$

${ }^{1}$ I.M.Sechenov First Moscow State Medical University, Department of Endocrinology, Faculty of Postgraduate Education, Moscow, Russian Federation, ${ }^{2}$ The Helmholtz Moscow Research Institute of Eye Diseases, Moscow, Russian Federation

\section{P80 CLINICAL CHARACTERISTICS AND TREATMENT OUTCOME IN PATIENTS WITH MODERATE GRAVE'S ORBITOPATHY \\ Hristozov $K^{1}$, Petrova $M^{1}$, Siderova $M^{1}$, Zlatanova $E^{1}$ \\ ${ }^{1}$ Medical University - Varna, Clinic of Endocrinology, Varna, Bulgaria}

\section{P81 COMPARISON EFFICACY OF DIFFERENT SCHEMES OF GRAVES' ORBITOPATHY TREATMENT}

Shestakova $T^{1}$, Dreval $A^{1}$, Perepelova $\mathrm{O}^{1}$, Nechaeva $\mathrm{O}^{1}$

${ }^{1}$ Moscow Regional Research Clinical Institute

n.M.F Vladimirskii, Endocrinology, Moscow, Russian Federation

P82 THE CA/OA RATIO AS A TOOL FOR PLANNING SURGERY IN PATIENTS SUBMITTED TO ORBITAL DECOMPRESSION FOR GRAVES' ORBITOPATHY (GO) Campi I' ${ }^{1}$, Vannucchi $G^{1}$, Covelli $D^{1}$, Brevi $A^{2}$, lofrida $E^{2}$, Currò $N^{3}$, Guastella $C^{2}$, Pignataro $L^{2}$, Avignone $S^{4}$, Beck-Peccoz $P^{1,5}$, Salvi $M^{1}$ ${ }^{1}$ Fondazione IRCCS Ca' Granda, Department of Clinical Science and Community Health, Milan, Italy, ${ }^{2}$ Fondazione IRCCS Ca' Granda, Otolaryngology, Milan, Italy, ${ }^{3}$ Fondazione IRCCS Ca' Granda, Ophthalmology, Milan, Italy, 'Fondazione IRCCS Ca' Granda, Neuroradiology, Milan, Italy, ${ }^{5}$ Università degli Studi di Milano, Milan, Italy

\section{P83 DIFFERENT FEATURES OF GRAVES'}

OPHTHALMOPATHY IN TYPE 1 AND TYPE 2 DIABETES

Le Moli $R^{1}$, Muscia $V^{1}$, Castoro $C^{1}$, Furneri $M T^{1}$, Regalbuto $C^{1}$, Squatrito $S^{1}$, Vigneri $R^{1}$

${ }^{1}$ Catania University, Biomedicine Clinical and Molecular, Catania, Italy

\section{P84 THYROID AUTOANTIBODIES IN GRAVES'} ORBITOPATHY: DIFFERENCES BETWEEN HYPERTHYROID AND EUTHYROID PATIENTS

Beleslin $B^{1}$, Ciric $J^{1}$, Zarkovic $M^{1}$, Stojkovic $M^{1}$, Ciric $S^{1}$, Lalic $T^{1}$, Trbojevic $B^{7}$

${ }^{1}$ Clinic of Endocrinology, Diabetes and Metabolic Disorders, Clinical Center of Serbia, Belgrade, Serbia 
P85 LATE RELAPSE OF GRAVES OPHTHALMOPATHY IN A CASE WITH TREATED GRAVES' DISEASE

Simescu MM ${ }^{1}$, Podia Igna $C C^{2}$, Parlog Cristian $A L^{3}$

${ }^{1}$ SC SIMEDIS CONSULT SRL, Endocrinology, Bucharest, Romania, ${ }^{2}$ Astra Clinic, Endocrinology, Sibiu, Romania,

${ }^{3}$ MEDLIFE, Endocrinology, Bucharest, Romania

\section{P010 Hyperthyroidism 1}

Chair: Mario Salvi, Italy

\section{P86 ANTI-THYROID DRUGS AS TREATMENT FOR}

\section{NEUTROPENIA IN GRAVES' THYROTOXICOSIS}

Aggarwal $N^{1}$, Saqib $W^{1}$, Fretwell $T^{1}$, Razvi $S S^{1,2}$

${ }^{1}$ Queen Elizabeth Hospital, Endocrinology, Gateshead, United Kingdom, ${ }^{2}$ Newcastle University, Endocrinology, Gateshead, United Kingdom

P87 PROSPECTIVE STUDY ON THE TRIGGERING ROLE OF STRESS IN GRAVES' DISEASE (GD)

Vita $R^{1}$, Lapa $D^{1}$, Trimarchi $F^{1}$, Benvenga $S^{1}$

${ }^{1}$ University of Messina, Department of Clinical \& Experimental Medicine, Messina, Italy

\section{P88 PLASMA BRAIN NATRIURETIC PEPTIDE (BNP) IN GRAVES' HYPERTHYROIDISM WITH OR WITHOUT ATRIAL FIBRILLATION}

Okamura K' Bandai $S^{1}$, Fujikawa $M^{1}$, Sato $K^{1}$, Chishaki $A^{2}$, Kitazono $T^{1}$

${ }^{1}$ Kyushu University, 2nd Dept Intern Med, Fukuoka, Japan,

${ }^{2}$ Kyushu University, Dept Health Sciences, Fukuoka, Japan

\section{P89 THYROID FUNCTION STATUS IN PATIENTS} RECEIVING HEMODIALYSIS AND PERITONEAL DIALYSIS FOR CHRONIC KIDNEY DISEASE

Darvishnia ${ }^{1}$, Emmami $A^{1}$

${ }^{1}$ Isfahan University of Medical Sciences, Esfahan, Islamic Republic of Iran

\section{P90 LEVELS OF TSH, FREE T4 AND ANTI-TPO LEVELS} IN AN EUTHYROID BULGARIAN POPULATION WITHOUT HISTORY, LABORATORY OR ULTRASOUND DATA OF THYROID DISEASE

Shinkov $A^{1}$, Borissova A-M $M^{1}$, Vlahov $J^{1}$, Dakovska $L^{1}$

${ }^{1}$ Medical University of Sofia, Clinical Center of Endocrinology, Sofia, Bulgaria
P91 AN INTRIGUING CASE OF HYPOTHYROID WOMAN BECOMING HYPERTHYROID

Kudugunti $N^{1}$, Sahay $R K^{1}$, Kumaresan $K^{2}$

${ }^{1}$ Osmania Medical College, NTR University of Health Sciences, Endocrinology, Hyderabad, India, ${ }^{2}$ K.K Nuclear Scan, Nuclear Medicine, Hyderabad, India

\section{P92 TRANSIENT THYROTOXICOSIS DIFFERENT FROM} SUBACUTE THYROIDITIS

Milicevic Z

${ }^{1}$ Vinca Institute of Nuclear Sciences, Laboratory of Molecular Biology and Endocrinology, Belgrade, Serbia

P93 LATE RECURRENCES OF GRAVES HYPERTHYROIDISM AFTER SURGICAL THERAPY

Ursu $\mathrm{HI}^{1,2}$, Galoiu $\mathrm{S}^{1,2}$, Podia $\mathrm{Cl}^{3}$, Purice $\mathrm{M}^{4}$, Stanescu $\mathrm{B}^{2,5}$,

Goldstein $A^{4}$, Alexandrescu $D^{6}$

${ }^{1}$ C.I. Parhon' Institute of Endocrinology, Thyroid Unit 1, Bucharest, Romania, ${ }^{2}$ Carol Davila' University of Medicine and Pharmacy, Endocrinology, Bucharest, Romania, ${ }^{3}$ Astra' Polyclinic, Sibiu, Romania, ${ }^{4}$ C.I. Parhon' Institute of Endocrinology, Nuclear Medicine, Bucharest, Romania,

${ }^{5}$ C.I. Parhon' Institute of Endocrinology, Endocrine Surgery, Bucharest, Romania, ${ }^{6}$ C.I. Parhon' Institute of Endocrinology, Ophthalmology, Bucharest, Romania

\section{P94 LITHIUM-ASSOCIATED HYPERPARATHYROIDISM: A CASE REPORT}

Marcelino $M^{1}$, Silva $J^{1}$, Lopes $F^{1}$, Lopes $L^{1}$, Salgado $L^{2}$, Lopes $C^{3}$, de Castro JJ'

${ }^{1}$ Armed Forces University Hospital, Endocrinology, Lisbon, Portugal, ${ }^{2}$ Armed Forces University Hospital, Nuclear Medicine, Lisbon, Portugal, ${ }^{3}$ Armed Forces University Hospital, Surgery, Lisbon, Portugal 
Poster Exhibition Area

12.00-13.00

Poster Session 2

P011 Thyroid Autoimmunity Clinical

Chair: Stefano Mariotti, Italy

P95 THE CONTRIBUTION OF POLYMORPHISMS WITHIN GENES ENCODING CO-STIMULATORY MOLECULES TO THE SUSCEPTIBILITY TO GRAVES' DISEASE AND ORBITOPATHY Pawlak-Adamska E', Daroszewski I ${ }^{1}$, Frydecka I', Karabon L', Jonkisz $A^{7}$, Tomkiewicz $A^{7}$, Partyka $A^{7}$, Lebioda $A^{3}$, Bolanowski $M^{2}$ ${ }^{1}$ Institute of Immunology and Experimental Therapy, Polish Academy of Sciences, Wroclaw, Poland, ${ }^{2}$ Wroclaw Medical University, Dept. of Endocrinology, Diabetes and Isotope Therapy, Wroclaw, Poland, ${ }^{3}$ Wroclaw Medical University, Dept. of Forensic Medicine, Wroclaw, Poland

\section{P96 SELENOMETHIONINE SUPPLEMENTATION IN} EUTHYROID PATIENTS WITH AUTOIMMUNE THYROIDITIS: EFFECTS OF TWO DOSES (80 OR $160 \mu \mathrm{G})$ VERSUS PLACEBO Cenci $V^{1}$, Pilli $T^{1}$, Cardinale $S^{1}$, Cantara $S^{1}$, Fioravanti $C^{1}$, Sestini $F^{1}$, Pasqui $L^{1}$, Pacini $F^{1}$

${ }^{1}$ University of Siena, Section of Endocrinology, Department of Medical, Surgical and Neurological Sciences, Siena, Italy

\section{P97 CHRONIC LYMPHOCITIC THYROIDITIS (CLT) IS INCREASED IN INDUSTRIALIZED AREAS WITH PETROCHEMICAL PLANTS IN SOUTH-EASTERN SICILY. A CYTOLOGICAL-BASED STUDY}

Arena $S^{1}, \underline{\text { Gullo } D^{2}}$, Latina $A^{2}$, Benvenga $S^{3}$

${ }^{1}$ A.S.P. 8 - Umberto I Hospital, Internal Medicine, Section of Endocrinology and Metabolic Disease, Siracusa, Italy, ${ }^{2}$ Garibaldi-Nesima Hospital, Endocrinology, Catania, Italy, ${ }^{3}$ University of Messina, Department of Clinical and Experimental Medicine, Messina, Italy

\section{P98 EFFECTS OF STEROID PROPHYLAXIS FOR GRAVES'} ORBITOPATHY ON THE RADIOIODINE (RAI) THERAPEUTIC OUTCOME AND THYROID FUNCTION

Covelli $D^{1}$, Vannucchi $G^{1}$, Campi I ${ }^{1}$, Currò $N^{2}$, Dazzi $D^{3}$, Rodari $M^{4}$, Pepe $G^{4}$, Chiti $A^{4}$, Beck-Peccoz $P^{1}$, Salvi $M^{1}$

${ }^{1}$ Endocrine Unit, Department of Clinical Science and Community Health, Fondazione Cà Granda Policlinico IRCCS, Milan, Italy, ${ }^{2}$ Ophthalmology, Fondazione IRCCS Cà Granda, Milan, Italy, ${ }^{3}$ Internal Medicine, Ospedale di Fidenza, Fidenza, Italy, ${ }^{4}$ Nuclear Medicine, Istituto Clinico Humanitas, Rozzano, Italy
P99 PENDRIN AUTOANTIBODIES, USING A

RADIOLIGAND BINDING ASSAY, ARE DETECTED WITH LOW FREQUENCY IN PATIENTS WITH AUTOIMMUNE THYROID DISEASE AND ARE UNDETECTABLE IN NORMAL CONTROLS Brix $T H^{1}$, Hegedüs $L^{1}$, Weetman $T^{2}$, Kemp $H^{2}$

${ }^{1}$ Odense University Hospital, Endocrinology and Metabolism, Odense, Denmark, ${ }^{2}$ Medical School, University of Sheffield, Department of Human Metabolism, Sheffield, United Kingdom

P100 OXIDATIVE STRESS IS ASSOCIATED WITH THYROID HORMONES AND THYROID AUTOIMMUNITY IN EUTHYROID WOMEN

Giannakou $M^{1}$, Saltiki K1, Loukari E1 , Mantzou A ${ }^{1}$, Philippou $G^{1}$, Terzidis $K^{1}$, Stavrianos $C^{1}$, Alevizaki $M^{1}$

${ }^{1}$ Athens University School of Medicine, Dept of Endocrinology and Metabolism 'Evgenidion' Hospital, Athens, Greece

P101 PRIMARY THYROID DISORDERS IN PATIENTS WITH ENDOGENOUS HYPERCORTISOLISM AND THE ROLE OF IMMUNE DYSREGULATION: AN OBSERVATIONAL STUDY Demir Onal E $E^{1}$, Sağlam $F^{1}$, Saçıkara $M^{1}$, Ersoy $R^{1}$, Çakır $B^{1}$ ${ }^{1}$ Yıldırım Beyazıt University Ankara Atatürk Education and Research Hospital, Endocrinology and Metabolism, Ankara, Turkey

P102 FACTORS INFLUENCING GRAVES' DISEASE RECURRENCE AFTER SUCCESSFUL TREATMENT WITH ANTITHYROID DRUGS

Zaletel $K^{1}$, Arko $R^{2}$, Gaberšček $S^{1}$, Pirnat $E^{1}$, Hojker $S^{1}$

${ }^{1}$ University Medical Centre Ljubljana, Department of Nuclear Medicine, Ljubljana, Slovenia, ${ }^{2}$ Faculty of Medicine, University of Ljubljana, Ljubljana, Slovenia

P103 THYROID AUTOIMMUNITY IN PATIENTS WITH HYPERPROLACTINEMIA: AN OBSERVATIONAL STUDY Demir Onal E' $E^{1}$ Sağlam $F^{1}$, Saçıkara $M^{1}$, Ersoy $R^{1}$, Çakır $B^{1}$ ${ }^{1}$ Yıldırım Beyazıt University Medical School Ankara Atatürk Education and Research Hospital, Endocrinology and Metabolism, Ankara, Turkey

\section{P104 AUTOIMMUNE THYROIDITIS AND PAPILLARY THYROID CANCER}

Podoba J', Grigerová $M^{2}$, Podobová $M^{2}$

${ }^{1}$ Slovak Medical University, Dept. Endocrinology, Bratislava, Slovakia, ${ }^{2}$ St. Elizabeth Cancer Institute, Dept. Endocrinology, Bratislava, Slovakia 


\section{P012 Thyroid Cancer Basic 2}

Chair: Dagmar Führer, Germany

P105 DISTINCT GENETIC ALTERATIONS IN MAPK PATHWAY MODULATE TYPE 3 DEIODINASE IN HUMAN PTC CELL LINES

Romitti $M^{1}$, Wajner $S M^{1}$, Pinto Ribeiro RV ${ }^{1}$, Ceolin $L^{1}$, Ferreira $C V^{1}$, Rohenkohl $\mathrm{HC}^{1}$, Fuziwara $\mathrm{CS}^{2}$, Edna $\mathrm{KT}^{2}{ }^{2}$, Maia $\mathrm{AL}^{1}$

'Universidade Federal do Rio Grande do Sul, Hospital de Clínicas de Porto Alegre, Porto Alegre, Brazil, ${ }^{2}$ Universidade de São Paulo, Institute of Biomedical Science, São Paulo, Brazil

P106 IMPORTANCE OF THE TRANSIENT RECEPTOR POTENTIAL CANONICAL 1 (TRPC1) CHANNEL IN THE MIGRATION AND PROLIFERATION OF FOLLICULAR ML-1 THYROID CANCER CELLS

Asghar MY $Y^{1}$, Magnusson $M^{1}$, Kemppainen $K^{1}$, Bergelin $N^{2}$, Törnquist $K^{1,2}$

${ }^{1}$ Åbo Akademi University, Biosciences, Turku, Finland, ${ }^{2}$ The Minerva Foundation Institute for Medical Research, Helsinki, Finland

\section{P107 THE USE OF PGLA NANOPARTICLES AS A DELIVERY}

SYSTEM OF DIFFERENT ANTITUMOURAL DRUGS AS A CONTROL OF THE PROLIFERATION CELLS IN THE EPITHELIAL THYROID NEOPLASIAS

Mato $E^{1,2,3}$, Bordas $A^{1}$, Puras $G^{4}$, Zararte $J^{4}$, Hernández $R M^{4}$, Igartua $\mathrm{M}^{4}$, González $\mathrm{C}^{1,2}$, Bell $\mathrm{O}^{1,2}$, Moral $\mathrm{A}^{5}$, Pérez $\mathrm{Jl}^{5}$, Pedraz $\mathrm{JL}^{4}$, de Leiva $A^{1,2}$

${ }^{1}$ Networking Research Center on Bioengineering, Biomaterials and Nanomedicine (CIBER-BBN), Endocrinology, Barcelona, Spain, ${ }^{2}$ EUADB-HSP Hospital Santa Creu i Sant Pau, Autonomous University, Barcelona, Spain, ${ }^{3}$ Departamento de Biología Celular, Inmunología y Neurociencias Facultad de Medicina UB, Barcelona, Spain, ${ }^{4}$ NanoBioCel Group, at the Department of Pharmacy and Food Sciences, Faculty of Pharmacy, University of the Basque Country, Vitoria, Spain, ${ }^{5}$ General Surgery, Hospital de la Santa Creu I Sant Pau, Barcelona, Spain

\section{P108 MOLECULAR EPIDEMIOLOGY STUDY OF} CHERNOBYL THYROID CANCER FROM BELARUS AND UKRAINE

Saenko V1', Takahashi $\mathrm{M}^{2}$, Rogounovitch $\mathrm{Tl}^{3}$, Akulevich $\mathrm{NM}^{4}$, Drozd VM ${ }^{4}$, Danilova LI ${ }^{4}$, Lushchyk $\mathrm{ML}^{4}$, Demidchik YE ${ }^{4}$, Bogdanova $\mathrm{TI}^{5}$, Tronko $\mathrm{MD}^{5}$, Mitsutake $\mathrm{N}^{3}$, Takamura $\mathrm{N}^{6}$, Matsuda $F^{2}$, Yamashita $S^{1,3}$

${ }^{1}$ Nagasaki University, Department of Health Risk Control, Nagasaki, Japan, ${ }^{2}$ Kyoto University Graduate School of Medicine, Center for Genomic Medicine, Kyoto, Japan, ${ }^{3}$ Nagasaki University, Department of Radiation Medical Sciences, Nagasaki, Japan, ${ }^{4}$ Belarusian Medical Academy for Postgraduate Education, Minsk, Belarus, ${ }^{5}$ Institute of Endocrinology and Metabolism, Kiev, Ukraine, ${ }^{6}$ Nagasaki University, Department of Global Health, Medicine and Welfare, Nagasaki, Japan
P109 THYROCYTE IS PARTICULARLY WELL PROTECTED AGAINST OXIDATIVE STRESS INDUCED BY $\mathrm{H} 2 \mathrm{O} 2$ Ghaddhab $C^{1}$, Hancisse $O^{1}$, Versteyhe ${ }^{1}$, Driessens $N^{1}$, Dumont JE', Miot F', Corvilain $B^{1}$

${ }^{1}$ ULB, Brussels, Belgium

P110 a-LIPOIC ACID INHIBITS EPITHELIAL TO MESENCHYMAL TRANSITION IN THYROID CANCER CELLS Kim WG ${ }^{1}$, Choi H- $\mathrm{J}^{2}$, Han JM ${ }^{1}$, Kim $T Y^{1}$, Shong YK $K^{1}$, Kim WB'

${ }^{1}$ Asan Medical Center, University of Ulsan College of Medicine, Internal Medicine, Seoul, Korea, Republic of, ${ }^{2}$ Asan Institute of Life Science, Seoul, Republic of Korea

P111 CELLULAR ABSORPTION OF SUPERPARAMAGNETIC IRON OXIDE NANOPARTICLES IN HUMAN THYROID CANCER (FB3) AND FIBROBLASTIC CELL LINES (NHDF): IN VITRO STUDY

Pasqualetti $G^{7}$, Di Bari $L^{2}$, Ursino $S^{3}$, Lenzi $P^{4}$, Tognini $S^{3}$, Polini $A^{3}$, Vitulli $G^{2}$, Vantaggiato $C^{3}$, Barbaro $D^{5}$, Fornai $F^{4}$, Salvatori $P^{2}$, Monzani $F^{3}$

${ }^{1}$ University of Pisa, Department of Clinical and Experimental Medicine, Geriatrics Unit, Pisa, Italy, ${ }^{2}$ Advanced Catalysts S.r.l., Pisa, Italy, ${ }^{3}$ University of Pisa, Department of Clinical and Experimental Medicine, Pisa, Italy, ${ }^{4}$ University of Pisa, Department of Translational Research and New Technology in Medicine, Pisa, Italy, ${ }^{5}$ Livorno Hospital, Department of Internal Medicine, Livorno, Italy

P112 AFTER 20 YEARS, RET GENETIC SCREENING STILL INDENTIFIES NEW GERMILINE AND SOMATIC MUTATIONS Tacito $A^{1}$, Romei $C^{1}$, Vivaldi $A^{1}$, Ciampi $R^{1}$, Matrone $A^{1}$, Bottici $V^{1}$, Cappagli $V^{1}$, Elisei $R^{1}$

${ }^{1}$ University of Pisa, Section of Endocrinology, Department of Clinical and Experimental Medicine, Pisa, Italy

P113 MISSENSE POLYMORPHISMS IN XIAP-ASSOCIATED FACTOR 1 (XAF1) AND RISK OF PAPILLARY THYROID CANCER IN KOREAN POPULATION : CORRELATION WITH CLINICOPATHOLOGIC FEATURES

Kim SW ${ }^{1},{\underline{K w o n ~} \mathrm{KH}^{2}}^{2}$

${ }^{1}$ VHS Medical Center, Department of Otolaryngology-Head and Neck Surgery, Seoul, Korea, Republic of, ${ }^{2}$ Ilsong Memorial Institute of Head and Neck Cancer, Hallym University College of Medicine, Department of Otolaryngology-Head and Neck Surgery, Seoul, Republic of Korea

\section{P114 LESS INTRATUMORAL MICROVESSELS AND MORE NUMEROUS PERITUMORAL LYMPHATIC VASCULATURE IN RECURRENT THYROID CANCERS}

Hakala $T^{1}$, Kholová $I^{2}$, Kellokumpu-Lehtinen $P-L^{1}$, Sand $J^{1}$ ${ }^{1}$ Tampere University Hospital, Tampere, Finland, ${ }^{2}$ Fimlab Laboratories, Pathology, Tampere, Finland 
P115 PARVOVIRUS B 19 AS AN ETIOLOGICAL AGENT OF PAPILLARY THYROID CANCER IN A KOREAN POPULATION Lee $I^{1}$, Jang $Y S^{1}, K_{i m} H S^{1}$, Lee $K J^{1}$, Lee $D H^{1}$, Lee $J M^{1}$

${ }^{1}$ The Catholic University College of Medicine, Daejeon,

Republic of Korea

P013 Thyroid Cancer Diagnostics 2

Chair: Ulla Feldt-Rasmussen, Germany

P116 CORRELATION OF THE PRESURGICAL DIAGNOSIS OF FOLLICULAR VARIANT OF PAPILLARY THRYOID CANCER WITH THE DISEASE STATUS AFTER 10 YEARS OF FOLLOW UP Giani $C^{1}$, Torregrossa $L^{2}$, Angeli $M^{1}$, Molinaro $E^{1}$, Cacciato Insilla $A^{2}$, Materazzi $G^{2}$, Marchetti ${ }^{3}$, Basolo $F^{2}$, Miccoli $P^{2}$, Di Coscio $G^{3}$, Elisei $R^{1}$

${ }^{1}$ Endocrine Unit, Department of Clinical and Experimental Medicine, University of Pisa, Pisa, Italy, ${ }^{2}$ Department of Surgical, Medical and Molecular Pathology of the Clinical Area, University of Pisa, Pisa, Italy, ${ }^{3}$ Department of Translational Research and New Technologies in Medicine and Surgeons, University of Pisa, Pisa, Italy

P117 IDENTIFICATION OF SOMATIC MUTATIONS BY MATRIX-ASSISTED LASER DESORPTION IONIZATION TIME-OF-FLIGHT MASS SPECTROMETRY IN FINE NEEDLE ASPIRATION OF PAPILLARY THYROID CANCER

Cho $Y Y^{1}$, Joung $\mathrm{JY}^{1}$, Kim NK${ }^{1}$, Sohn SY ${ }^{1}$, Kim SW ${ }^{1}$, Chung $\mathrm{JH}^{1}$

${ }^{1}$ Samsung Medical Center, Sungkyunkwan University School of Medicine, Seoul, Republic of Korea

P118 CLINICAL PREDICTORS OF PERSISTENT DISEASE IN PATIENTS WITH BRAFV600E MUTATED PAPILLARY THYROID CANCER (PTC)

Repaci $A^{1}$, Vicennati $V^{1}$, Paccapelo $A^{1}$, Cavicchi $O^{2}$, Monari $F^{3}$, Mazzarotto $R^{3}$, Tallini $G^{4}$, Altimari $A^{5}$, Gruppioni $E^{5}$, Fiorentino $M^{5}$, Pasquali $R^{1}$

'Sant'Orsola-Malpighi Hospital/University of Bologna, Endocrinology Unit, Bologna, Italy, ${ }^{2}$ Sant'Orsola-Malpighi Hospital/University of Bologna, Department of Otolaryngology, Bologna, Italy, ${ }^{3}$ Sant'Orsola-Malpighi Hospital/University of Bologna, Department of Radiotherapy, Bologna, Italy,

${ }^{4}$ Department of Haematology and Oncological Sciences L. and A. Seragnoli, Section of Anatomic Pathology at Bellaria Hospital, University of Bologna Malpighi Università di Bologna, Bologna, Italy, ${ }^{5}$ Molecular and Transplantation Pathology Laboratory,

'F. Addarii'/ Sant'Orsola-Malpighi Hospital/University of Bologna, Bologna, Italy

P119 THE EVALUATION OF SALIVARY GLAND DYSFUNCTION AFTER I-131 THERAPY IN PATIENTS FOLLOWING TOTAL THYROIDECTOMY

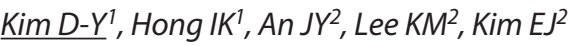

${ }^{1}$ Kyung Hee University Hospital, Nuclear Medicine, Seoul, Republic of Korea, ${ }^{2}$ Kyung Hee University Hospital, Radiology, Seoul, Republic of Korea
P120 THE DISCORDANCE BETWEEN PRE-OPERATIVE AND POST-OPERATIVE BRAF MUTATION ANALYSIS OF PAPILLARY THYROID CANCER BY US-GUIDED FNA: ULTRASOUND FEATURES

$\underline{K i m ~ S}^{1}$, Park $\mathrm{SH}^{1}$, Lee $\mathrm{SJ}^{1}$, Hur J1

${ }^{1}$ Chung-Ang University, Seoul, Republic of Korea

P121 DO CHARACTERISTICS OF PAPILLARY THYROID CARCINOMAS CORRELATE WITH PREOPERATIVE SERUM TSH CONCENTRATIONS?

Park J-W W $^{1}$, Kim D-J ${ }^{1}$

${ }^{1}$ Chungbuk National University, Department of Surgery, Cheongju, Republic of Korea

\section{P122 BASAL THYROGLOBULIN LEVELS MAY PREDICT} RECURRENT AND PERSISTENT DISEASE IN DIFFERENTIATED THYROID CANCER (DTC)

Aydoğan $B i^{1}$, Erdogan $M F^{1}$, Öztürk $B^{1}$, Özkan $E^{2}$, Şahin $M^{1}$, Emral $R^{1}$, Küçük Ö̈ , Çorapçıoğlu $D^{1}$, Başkal N ${ }^{1}$, Uysal $A R^{1}$, Güllü $S^{1}$

${ }^{1}$ Ankara University School of Medicine, Endocrinology and Metabolism Diseases, Ankara, Turkey, ${ }^{2}$ Ankara University School of Medicine, Nuclear Medicine, Ankara, Turkey

\section{P123 SILENT BONE METASTASES FROM DIFFERENTIATED} THYROID CANCER - A STUDY ON INCIDENCE AND OUTCOME OF TREATMENT

Kumaresan $K^{1}$, Dillikar $G^{1}$

${ }^{1}$ KK Nuclear Scans, Hyderabad, India

P124 VERY RARE METASTASES IN DIFFERENTIATED THYROID CANCER: DIAGNOSIS WITH 18F FDG PET/CT OR 131 I SPECT/CT IMAGING; ON BEHALF OF THE FRENCH TUTHYREF (TUMEURS DE LA THYROIDE REFRACTAIRES) NETWORK

Faugeron $I^{1}$, Bonichon $F^{2}$, Schvartz $C^{3}$, Dejax $C^{4}$, Bournaud $C^{5}$, Benisvy $D^{6}$, Leboulleux $S^{7}$, Méas $T^{1}$, Schneegans $O^{8}$, Toubert $M-E^{1}$ ${ }^{1}$ Saint-Louis Hospital, APHP, Nuclear Medicine, Paris, France, ${ }^{2}$ Institut Bergonie, Nuclear Medicine, Bordeaux, France, ${ }^{3}$ Centre Jean Godinot, Nuclear Medicine, Reims, France, ${ }^{4}$ Centre Jean Perrin, Nuclear Medicine, Clermont-Ferrand, France, ${ }^{5}$ Hospices Civils de Lyon, GH Est, Nuclear Medicine, Bron, France, ${ }^{6}$ Centre Antoine Lacassagne, Nuclear Medicine, Nice, France, ${ }^{7}$ Institut Gustave Roussy, Nuclear Medicine, Villejuif, France, ${ }^{8}$ Centre Paul Strauss, Nuclear Medicine, Strasbourg, France 
P014 Thyroid Nodules and Goitre 1

Chair: Laszlo Hegedüs, Denmark

P125 MCL-1 UPREGULATION AND P27 DOWNREGULATION DIFFERENTIATE THE PATHOGENESIS OF PAPILLARY THYROID CARCINOMA AND BENIGN THYROID NODULES: CLINICAL, SCINTIGRAPHY AND SONOGRAPHIC CORRELATIONS

Maia FFR ${ }^{1}$, Vassallo $\mathrm{J}^{2}$, Pinto $\mathrm{GA}^{3}$, Pavin EJ ${ }^{1}$, Matos PS ${ }^{4}$, Zantut-Wittmann DE ${ }^{1}$

${ }^{1}$ University of Campinas - UNICAMP, Internal Medicine, Endocrinology Division, Campinas, Brazil, ${ }^{2}$ Laboratory of Investigative and Molecular Pathology, CIPED, University of Campinas, Department of Pathology, Campinas, Brazil, ${ }^{3}$ Laboratory of Specialized Pathology, CAISM, Medical Science School, University of Campinas, Department of Pathology, Campinas, Brazil, ${ }^{4}$ Medical Science School, University of Campinas, Department of Pathology, Campinas, Brazil

P126 THE EFFECT OF HEMITHYROIDECTOMY FOR BENIGN EUTHYROID GOITER ON THE MITOCHONDRIAL MEMBRANE POTENTIAL OF PERIPHERAL MONONUCLEAR BLOOD CELLS Toft Kristensen $T^{1}$, Larsen $\mathcal{J}^{2}$, Pedersen $P L^{3}$, Feldthusen $A-D^{4}$, Anthonsen $S^{3}$, Jelstrup $S^{1}$, Kvetny $J^{5}$

${ }^{1}$ Department of Otorhinolaryngology - Head and Neck Surgery, Slagelse Hospital, Region Zealand, Slagelse, Denmark, ${ }^{2}$ Department of Clinical Pathology, Næstved Hospital, Region Zealand, Næstved, Denmark, ${ }^{3}$ Department of Clinical Biochemistry, Næstved Hospital, Region Zealand, Næstved, Denmark, ${ }^{4}$ Department of Gynecology and Obstetrics, Næstved Hospital, Region Zealand, Næstved, Denmark, ${ }^{5}$ University of Southern Denmark, Department of Internal Medicine, Naestved Hospital, Region Zealand, Næstved, Denmark

\section{P127 AN OPEN-LABEL, RANDOMIZED, CONTROLLED} STUDY OF THE EFFECTIVENESS AND SAFETY OF A HIGH INTENSITY FOCUSED ULTRASOUND DEVICE COMPARED WITH OBSERVATION IN PATIENTS WITH NON-MALIGNANT COLD THYROID NODULES

Leenhardt $L^{1}$, Rouxel $A^{1}$, Lacoste $F^{2}$, Menegaux $F^{3}$, Esnault $\mathrm{O}^{4}$

${ }^{1}$ Pierre et Marie Curie University, Nuclear Medicine, Paris, France, ${ }^{2}$ Theraclion, Paris, France, ${ }^{3}$ Pierre et Marie Curie University, Endocrine Surgery, Paris, France, ${ }^{4}$ ENT Department, Paris, France

\section{P128 ASSOCIATION BETWEEN REAL-TIME NODULE} ELASTOGRAPHY AND CLASSICAL MALIGNANCY RISK MARKERS BY ULTRASONOGRAPHY IN A REAL LIFE CLINICAL SETTING - A PROSPECTIVE PATIENT STUDY BEFORE THYROID SURGERY

Motavaf AK ${ }^{1}$, Brilli $L^{2}$, Pikeli $A^{3}$, Baymler Pedersen $H^{3}$, Laurberg $P^{1}$ ${ }^{1}$ Aalborg University Hospital, Department of Endocrinology, Aalborg, Denmark, ${ }^{2}$ University of Siena, Siena, Italy, ${ }^{3}$ Aalborg University Hospital, Department of ENT Head and Neck Surgery, Aalborg, Denmark
P129 THE ROLE OF BETHESDA CYTOLOGICAL CLASSIFICATION SYSTEM AND SONOGRAPHIC PARAMETERS TO DISCRIMINATE BENIGN AND MALIGNANCY IN THYROID NODULES $\geq 3$ CM

Maia FFR ${ }^{1}$, Matos PS ${ }^{2}$, Pavin EJ ${ }^{1}$, Vassallo $J^{3}$, Zantut-Wittmann DE ${ }^{1}$ University of Campinas - UNICAMP, Internal Medicine, Endocrinology Division, Campinas, Brazil, ${ }^{2}$ Medical Science School, University of Campinas, Department of Pathology, Campinas, Brazil, ${ }^{3}$ Laboratory of Investigative and Molecular Pathology, CIPED, University of Campinas, Department of Pathology, Campinas, Brazil

P130 EFFICACY, SAFETY AND COSTS OF THERMAL ABLATION WITH RADIOFREQUENCY COMPARED TO SURGERY FOR THE TREATMENT OF BENIGN THYROID NODULES

Bernardi $S^{1}$, Dobrinja $C^{2}$, Bazzocchi $G^{3}$, Sabato $N^{4}$, Barro $E^{4}$, Carretta $R^{4}$, Stacul $F^{3}$, Fabris $B^{4}$

${ }^{1}$ Ospedale di Cattinara, Medicina Clinica, Trieste, Italy, ${ }^{2}$ Ospedale di Cattinara, Chirurgia Generale, Trieste, Italy, ${ }^{3}$ Ospedale Maggiore, Radiologia, Trieste, Italy, ${ }^{4}$ University of Trieste, Dipartimento di Scienze Mediche Chirurgiche e della Salute, Trieste, Italy

P131 THIAMAZOL INCREASES IODINE UPTAKE AND ALLOWS A REDUCTION OF RADIOIODINE DOSE NEEDED TO TREAT SUBCLINICAL HYPERTHYROIDISM IN PATIENTS WITH MULTINODULAR GOITER

Kyrilli $A^{1}$, Blocklet $D^{2}$, Corvilain $B^{1}$, Goldman $S^{2}$, Moreno-Reyes $R^{2}$ ${ }^{1}$ Université Libre de Bruxelles, Department of Endocrinology, Brussels, Belgium, ${ }^{2}$ Université Libre de Bruxelles, Department of Nuclear Medicine, Brussels, Belgium

\section{P132 TWO NOVEL FORMULATIONS OF L-T4 (ORAL}

SOLUTION AND SOFT GEL CAPSULE) ARE REFRACTORY TO THE COFFEE-INDUCED INTESTINAL MALABSORPTION OF TABLET L-T4

Saraceno $G^{1}$, Vita $R^{1}$, Trimarchi $F^{1}$, Benvenga $S^{1}$

${ }^{1}$ University of Messina, Department of Clinical \& Experimental Medicine, Messina, Italy 
P015 Thyroid Cancer Therapeutics 2

Chair: Alicja Hubalewska-Dydejczyk, Poland

P133 BASELINE AGGRESSIVENESS AND LONG-TERM OUTCOME OF PAPILLARY THYROID CANCER IN PATIENTS WITH OR WITHOUT POSITIVE CIRCULATING ANTITHYROGLOBULIN ANTIBODY TITRE: RESULTS FROM A MULTICENTER, RETROSPECTIVE ANALYSIS

Tognini $S^{1}$, Durante $C^{2}$, Montesano $T^{2}$, Orlandi $F^{3}$, Torlontano $M^{4}$, Puxeddu $E^{5}$, Attard $M^{6}$, Polini $A^{1}$, Pasqualetti $G^{1}$, Costante $G^{7}$, Meringolo $D^{8}$, Tumino $S^{9}$, Bruno $R^{10}$, Monzani $F^{1}$, Filetti $S^{2}$ ${ }^{1}$ Università di Pisa, Dipartimento di Medicina Clinica e Sperimentale, Pisa, Italy, ${ }^{2}$ Università di Roma Sapienza, Dipartimento di Medicina Interna e Specialità Mediche, Roma, Italy, ${ }^{3}$ Università degli Studi di Torino, Dipartimento di Scienze Cliniche e Biologiche S.C.D.U, Torino, Italy, ${ }^{4}$ Istituto di Ricovero e Cura a Carattere Scientifico, Casa Sollievo della Sofferenza, San Giovanni Rotondo, Unità Operativa di Endocrinologia, San Giovanni Rotondo, Italy, ${ }^{5}$ Università di Perugia, Dipartimento di Medicina Interna, Perugia, Italy, ${ }^{6}$ Azienda Ospedaliera Ospedali Riuniti Villa Sofia-Cervello, Unità Operativa di Endocrinologia, Palermo, Italy, ${ }^{7}$ Università di Catanzaro Magna Graecia, Dipartimento di Scienze della Salute, Catanzaro, Italy, ${ }^{8}$ Ospedale di Bentivoglio, Unità Operativa Semplice Dipartimentale di Endocrinologia, Bologna, Italy, ${ }^{9}$ Università di Catania, Dipartimento di Scienze Mediche e Pediatriche, Catania, Italy, ${ }^{10}$ Ospedale di

Tinchi-Pisticci, Unità di Endocrinologia, Matera, Italy

P134 PREDICTION OF RISK FOR SYMPTOMATIC SIALADENITIS BY POST-THERAPEUTIC DUAL ${ }^{131}$ I SCINTIGRAPHY IN PATIENTS WITH DIFFERENTIATED THYROID CANCER

Lee $\mathrm{SM}^{1}$, Lee $\mathrm{JW}^{2}, \mathrm{Kim} \mathrm{YS}^{3}$, Han SW${ }^{4}$, Bae WK$K^{3}$

${ }^{1}$ Soonchunhyang University Hospital, Department of Nuclear Medicine, Cheonan, Republic of Korea, ${ }^{2}$ Yonsei University College of Medicine, Department of Nuclear Medicine, Seoul, Republic of Korea, ${ }^{3}$ Soonchunhyang University Hospital, Department of Radiology, Cheonan, Republic of Korea, ${ }^{4}$ Soonchunhyang University Hospital, Department of General Surgery, Cheonan, Republic of Korea

P135 TREATMENT OF PATIENTS WITH PATHOLOGY PROVEN HÜRTHLE CELL THYROID CARCINOMA WITH PEPTIDE RECEPTOR RADIONUCLIDE THERAPY USING THE RADIOACTIVE SOMATOSTATIN ANALOGUE [LU-177-DOTA0, TYR3]OCTREOTATE

Kam BLR ${ }^{1}$, Teunissen JJM ${ }^{1}$, Peeters $R P^{2}$, de Herder WW', Krenning $E P^{1}$, Kwekkeboom $D J^{1}$

${ }^{1}$ Erasmus Medical Center, Nuclear Medicine, Rotterdam, Netherlands, ${ }^{2}$ Erasmus Medical Center, Internal Medicine, Rotterdam, Netherlands
P136 CLINICAL SIGNIFICANCE OF DELPHIAN LYMPH NODE METASTASIS IN PAPILLARY THYROID CARCINOMA OhEM ${ }^{1}$, Cheung $Y S^{1}$, Song $W J^{1}$, Lee $Y D^{1}$

${ }^{1}$ Gachon Gil University Hospital, Thyroid Clinic, General Surgery, Incheon, Republic of Korea

P137 THE PREDICTION OF PATIENTS, UNNECESSARY OF STIMULATED THYROGLOBULIN TEST IN THE LONG TERM MANAGEMENT OF DIFFERENTIATED THYROID CARCINOMA Hyun $K^{1}$, Byon $W^{1}$, Yun J-S $S^{1}$, Park $Y^{1}$, Park $C^{1}$

${ }^{1}$ Kangbuk Samsung Hospital, Department: General Surgery, Seoul, Republic of Korea

P138 DIFFERENTIATED THYROID CANCER LOCALIZED IN THE THYROID ISTHMUS: IS THERE ANY SPECIFICITY? ${\underline{V i j a ~} L M^{1,2}}$, Meas $T^{3}$, Faugeron $1^{3}$, Toubert $M-E^{3}$

${ }^{1}$ APHP Hôpital Bicêtre, Biophysics and Nuclear Medicine, Le Kremlin-Bicêtre, France, ${ }^{2}$ Paris Sud University, Le Kremlin-Bicêtre, France, ${ }^{3}$ APHP Hôpital St Louis, Biophysics and Nuclear Medicine, Paris, France

\section{P139 LEVEL OF THYROGLOBULIN (TG) IN PATIENT WITH} PAPILLARY THYROID CARCINOMA (PTC) RECEIVED RADIO IODINE (RAI) ABLATION THERAPY

Frangos $S^{1}$, Patsali $L^{1}$, Vanezi $A^{1}$

${ }^{1}$ Bank of Cyprus Oncology Center, Nuclear Medicine, Strovolos-Nicosia, Cyprus

P140 PYRAMIDAL LOBE DIFFERENTIATED THYROID CARCINOMA: A RARE AND ATYPICAL LOCALIZATION ${\underline{\text { Vija } L M^{1,2}}}^{1}$, Meas $T^{3}$, Faugeron $1^{3}$, Toubert $M-E^{4}$

${ }^{1}$ APHP Hôpital Bicêtre, Biophysics and Nuclear Medicine, Le Kremlin-Bicêtre, France, ${ }^{2}$ Paris Sud University,

Le Kremlin-Bicêtre, France, ${ }^{3}$ APHP Hôpital St Louis, Paris, France, ${ }^{4}$ APHP Hôpital St Louis, Biophysics and Nuclear Medicine, Paris, France

P141 FOLLOW-UP OF CHILDREN WITH DIFFERENTIATED THYROID CANCER: AN INSTITUTIONAL EXPERIENCE Franceschi $M^{1}$, Jukić $T^{1}$, Granić $R^{1}$, Staničić $J^{1}$, Šiško Markoš $I^{1}$, Dabelić $N^{1}$, Punda $M^{1}$, Lukinac $L^{1}$, Kusić $Z^{1}$

'UHC'Sestre Milosrdnice', Zagreb Medical School, Department of Oncology and Nuclear Medicine, Zagreb, Croatia

\section{P016 Case Reports 2}

Chair: Bojan Lozanov, Bulgaria

P142 FIRST DESCRIPTION OF A PATIENT WITH CONGENITAL GOITROUS HYPOTHYROIDISM DUE TO SODIUM/IODIDE SYMPORTER (NIS) DEFECT AND THYROID CANCER

Bagattini $B^{1}$, Di Cosmo $C^{1}$, Montanelli $L^{1}$, Agretti $P^{1}$, De Marco $G^{1}$, Vitti $P^{1}$, Tonacchera $M^{1}$

${ }^{1}$ University of Pisa, Section of Endocrinology, Department of Clinical and Experimental Medicine, Pisa, Italy 
P143 A NEW TSHR VARIANT (L665F) AS THE MOLECULAR CAUSE FOR NON-AUTOIMMUNE HYPERTHYROIDISM IN AN AUSTRIAN FAMILY

Jaeschke $H^{1}$, Eszlinger $M^{1}$, Schaarschmidt $J^{1}$, Huth $S^{1}$, Puttinger $R^{2}$, Rittinger $\mathrm{O}^{2}$, Paschke $\mathrm{R}^{1}$

${ }^{1}$ University of Leipzig, Division of Endocrinology and Nephrology, Leipzig, Germany, ${ }^{2}$ University Hospital Salzburg, Department of Pediatrics, Salzburg, Austria

P144 REVERSIBLE CEREBRAL AND CEREBELLAR ATROPHY IN A PATIENT WITH HYPOTHYROIDISM

Tachibana $M^{1}$, Mukouhara $N^{1}$, Hirami $R^{1}$, Fujio $H^{1}$, Yumoto $A^{1}$

${ }^{1}$ Himeji Red Cross Hospital, Cardiology, Himeji, Japan

P145 GRAVES' DISEASE IN AN ADULT WITH CONGENITAL HYPOTHYROIDISM

Simpson $A^{1}$, Wilson $\mathrm{JD}^{1}$

${ }^{1}$ The Canberra Hospital, Endocrinology, Canberra, Australia

P146 POST-PARTY PARALYSIS (PPP)?

Cagiltay $E^{1}$, Deniz $F^{1}$, Ozsari $L^{1}$, Tekin $O^{2}$, Ozdemir $G^{2}$, Yonem $A^{1}$, Urhan $\mathrm{M}^{3}$

${ }^{1}$ GATA Haydarpasa Teaching Hospital, Endocrinology and Metabolism, Istanbul, Turkey, 'GATA Haydarpasa Teaching Hospital, Internal Medicine, Istanbul, Turkey, ${ }^{3}$ GATA

Haydarpasa Teaching Hospital, Nuclear Medicine, Istanbul, Turkey

P147 THYROTOXICOSIS DURING PREGNANCY, COMPLICATED BY ALLERGIES TO ANTI-THYROID DRUGS Carlos $A D C^{1}$, Rosales $R D^{1}$

${ }^{1}$ St.Luke's Medical Center, Section of Endocrinology, Diabetes and Metabolism, Quezon City, Philippines

P148 PRIMARY THYROID LYMPHOMA: A CASE REPORT Barbosa $L^{1}$, Póvoa $A A^{1}$, Wen $X^{2}$, Soares $C^{1}$, Furtado $A^{2}$, Vieira $H^{3}$, Oliveira $\mathrm{MJ}^{4}$, Tente $D^{2}$, Amândio $\mathrm{JV}^{1}$, Maciel JP ${ }^{1,5}$, Madaleno $P^{6}$ ${ }^{1}$ Centro Hospitalar de Vila Nova de Gaia / Espinho, EPE, Department of General Surgery, Vila Nova de Gaia, Portugal, ${ }^{2}$ Centro Hospitalar de Vila Nova de Gaia / Espinho, EPE, Department of Pathology, Vila Nova de Gaia, Portugal, ${ }^{3}$ Centro Hospitalar de Vila Nova de Gaia / Espinho, EPE, Department of Hematology, Vila Nova de Gaia, Portugal, ${ }^{4}$ Centro Hospitalar de Vila Nova de Gaia / Espinho, EPE, Department of Endocrinology, Vila Nova de Gaia, Portugal, ${ }^{5}$ Universidade Fernando Pessoa, Porto, Portugal, ${ }^{6}$ Centro Hospitalar de Vila Nova de Gaia / Espinho, EPE, Department of Radiology, Vila Nova de Gaia, Portugal

P149 STRESS INDUCED GRAVES' DISEASE: A CASE REPORT HIGHLIGHTING THE PRE AND POSTOPERATIVE IMPLICATIONS OF SUBCLINICAL THYROTOXICOSIS

Wilkinson $S^{1}$

${ }^{1}$ Trafford General Hospital, Foundation Programme,

Manchester, United Kingdom
P150 TOXIC ADENOMA A RISK FACTOR FOR THYROTOXIC HEART FAILURE

Ahmeti I ${ }^{1}$, Ristevska N², Strateska Shubevska S ${ }^{1}$, Pop Gjorceva D², Stojanoski S

${ }^{1}$ Clinic of Endocrinology, Diabetes and Metabolism, Skopje, the Former Yugoslav Republic of Macedonia, ${ }^{2}$ Institute of Pathophysiology and Nuclear Medicine, Skopje, the Former Yugoslav Republic of Macedonia

\section{P017 Clinical Thyroidology 2 \\ Chair: Joao de Castro, Portugal}

P151 THYROID-STIMULATING HORMONE AND THYROID VOLUME IN OBESE SUBJECTS

Formichi $C^{1}$, Brusco $L^{1}$, Ciuoli $C^{1}$, Chiofalo $F^{1}$, Selmi $F^{1}$, Neri $O^{1}$, Pasqui L', Pacini $F^{1}$

${ }^{1}$ University of Siena, Siena, Italy

\section{P152 THE GASTROINTESTINAL ABSORPTION OF IODINE IS NOT REDUCED AFTER MALABSORPTIVE BARIATRIC PROCEDURES}

Michalaki $M^{1}$, Volonakis $S^{1}$, Mamali ${ }^{1}$, Kalfarentzos $F^{2}$, Vagenakis $A G^{1}$, Markou $K B^{1}$

${ }^{1}$ University of Patras Medical School, Division of Endocrinology, Department of Internal Medicine, Patras, Greece, ${ }^{2}$ University of Patras Medical School, Department of Surgery, Patras, Greece

\section{P153 TREATMENT OF CENTRAL HYPOTHYROIDISM WITH} RECOMBINANT HUMAN TSH - A PILOT STUDY

Dixit $K^{1}$, Iwen $A^{2}$, Lehmphul ${ }^{3}$, Hoefig $C^{3}$, Köhrle ${ }^{3}$, Brabant $G^{1,2}$

${ }^{1}$ University of Manchester, Endocrinology - The Christie, Manchester, United Kingdom, ${ }^{2}$ University of Lübeck, Endocrinology, Lübeck, Germany, ${ }^{3}$ Charite, Institute of Experimental Endocrinology, Berlin, Germany

\section{P154 POLYMORPHISM SER49GLY $\beta$ 1-ADRENORECEPTOR} GENE AND FREQUENCY OF SUPRAVENTRICULAR ARRHYTHMIAS IN PATIENTS WITH THYREOTOXICOSIS

Grineva $E^{1}$, Babenko $A^{1}$, Hromova $N^{2}$, Savitskaya $D^{2}$, Kostareva $A^{2}$ ${ }^{1}$ Almazov Federal Heart, Blood and Endocrinology Centre, Institute of Endocrinology, Saint-Petersburg, Russian Federation, ${ }^{2}$ Almazov Federal Heart, Blood and Endocrinology Centre, Institute of Molecular Biology and Genetics,

Saint-Petersburg, Russian Federation

P155 SELENIUM SUPPLEMENTATION IN EUTHYROID PATIENTS WITH AUTOIMMUNE THYROIDITIS. A PILOT CONTROLLED STUDY

Guglielmi $R^{1}$, Misischi $I^{1}$, Graziano $F^{1}$, Chianelli $M^{1}$, Rinaldi $R^{1}$, Petrucci $L^{1}$, Papini $E^{1}$

${ }^{1}$ Regina Apostolorum Hospital, Endocrinology, Albano Laziale, Italy 
P156 INFLUENCES ON SKIN MICROCIRCULATION IN HYPERTHYROID PATIENTS WITH GRAVES' DISEASE

Bedernjak Bajuk $N^{1}$, Zaletel $K^{1}$, Gaberšček $S^{1}$, Lenasi $H^{2}$

${ }^{1}$ University Medical Centre Ljubljana, Department of Nuclear

Medicine, Ljubljana, Slovenia, ${ }^{2}$ University of Ljubljana, Institute of Physiology, Faculty of Medicine, Ljubljana, Slovenia

\section{P157 Poster has been withdrawn}

P158 CONCOMITANT THYROID AND THYMIC EXERESIS IN SURGERY OF HYPERPARATHYROIDISM

Diaconescu MR ${ }^{1}$, Glod $M^{1}$, Costea I ${ }^{1}$, Grigorovici $M^{2}$, Diaconescu $S^{3}$ ${ }^{1}$ Gr T Popa' University of Medicine and Pharmacy, Surgery (IVth Surgical Clinic), Iasi, Romania, ${ }^{2}$ University CF Hospital, Pathology, lasi, Romania, ${ }^{3 \prime} \mathrm{Gr}$ T Popa' University of Medicine and Pharmacy, Pediatrics (Vth Pediatric Clinic), lasi, Romania

\section{P018 Environmental Influences on Thyroid Function \\ Chair: Leonidas Duntas, Greece}

P159 PREVIOUS PREGNANCY IS A MAJOR RISK FACTOR FOR AUTOIMMUNE HYPOTHYROIDISM IN YOUNG WOMEN - A POPULATION-BASED CASE-CONTROL STUDY

Carlé $A^{1}$, Knudsen $N^{2}$, Pedersen $I B^{1}$, Ovesen $L^{3}$, Rasmussen $L B^{4}$, Jørgensen $T^{5,6}$, Perrild $H^{2}$, Laurberg $P^{1,6}$, all from the DanThyr group (The Danish Investigation on lodine Intake and Thyroid Diseases)

${ }^{1}$ Aalborg University Hospital, Department of Endocrinology \& Medicine, Aalborg, Denmark, ${ }^{2}$ Bispebjerg Hospital, Endocrine Unit, Medical Clinic I, Bispebjerg, Copenhagen, Denmark, ${ }^{3}$ Slagelse Hospital, Department of Internal Medicine, Slagelse, Denmark, ${ }^{4}$ Technical University of Denmark, Ministry of Food, Agriculture and Fisheries, National Food Institute, Copenhagen, Denmark, ${ }^{5}$ Copenhagen County, Research Centre for Disease Prevention and Health, Copenhagen, Denmark, ${ }^{6}$ University of Aalborg, Faculty of Medicine, Aalborg, Denmark

P160 INCREASED INCIDENCE OF THYROID DISORDERS IN ADULT POPULATION OF UKRAINE AFTER THE CHERNOBYL NPP ACCIDENT IS RELATED TO COMPLEX HORMONAL PATHWAYS

Kaminskyi OV' ${ }^{1}$ Afanasyev DE ${ }^{1}$, Kiselova $I^{2}$, Tepla OV 1

${ }^{1}$ State Enterprise 'National Research Center for Radiation Medicine of AMS of Ukraine', Endocrinology, Kiev, Ukraine, ${ }^{2}$ Kiev City Center of Clinical Endocrinology, Kiev, Ukraine
P161 INFLUENCE OF EXCESSIVE IODINE INTAKE ON THYROID FUNCTION AND PREVALENCE OF THYROID ABNORMALITIES IN ADULT POPULATION IN SVERDLOVSK REGION OF RUSSIA

Kiyaev $A^{1}$, Abdulhabirova $F^{2}$, Platonova $N^{2}$, Troshina $E^{2}$, Gerasimov $G^{3}$

'Ural Medical Academy, Yekaterinburg, Russian Federation, ${ }^{2}$ Federal Endocrinological Research Center, Moscow, Russian Federation, ${ }^{3}$ ICCIDD, Moscow, Russian Federation

\section{P162 INTERACTION OF SERUM COPPER WITH THYROID} HORMONES IN POSTMENOPAUSAL WOMEN

Rijntjes $E^{1}$, Pietschmann $N^{1}$, Gogakos $A^{2}$, Hoeg $A^{1}$, Reid $D^{3}$, Gluer $C^{4}$, Murphy $E^{2}$, Felsenberg $D^{5}$, Roux $C^{6}$, Eastell $R^{7}$, Williams $G^{2}$, Schomburg $L^{1}$

${ }^{1}$ Charité-Universitätsmedizin Berlin, Institute for Experimental Endocrinology, Berlin, Germany, ${ }^{2}$ Molecular Endocrinology Group, Imperial College London, Department of Medicine, London, United Kingdom, ${ }^{3}$ School of Medicine and Dentistry, University of Aberdeen, Aberdeen, United Kingdom, ${ }^{4}$ Klinik fuer Diagnostische Radiologie, Universitaetsklinikum SH, Kiel, Germany, ${ }^{5}$ Center for Muscle and Bone Research, Charite-Universitaetsmedizin Berlin, Berlin, Germany, ${ }^{6}$ Paris Descartes University, Department of Rheumatology, Paris, France, ${ }^{7}$ Bone Biomedical Research Unit, University of Sheffield, Sheffield, United Kingdom

\section{P163 PITFALLS OF THYROID SCREENING IN CHILDREN AFTER NUCLEAR POWER PLANT ACCIDENT IN FUKUSHIMA, JAPAN \\ Kikuchi S1 ${ }^{1}$, Kikuchi $T^{1}$, Kikuchi $K^{1}$, Yokozawa $T^{2}$ \\ ${ }^{1}$ Kikuchi Pediatric Clinic, Koriyama, Japan, ${ }^{2}$ Sakuragaoka \\ Genaral Hospital, Shimizu, Japan}

P164 THYROID FUNCTION IN HEALTHY SUBJECTS AND IN EUTHYROID PATIENTS WITH HASHIMOTO'S THYROIDITIS THREE YEARS BEFORE AND THREE YEARS AFTER INCREASE IN MANDATORY SALT IODIZATION

Gaberšček $S^{1,2}$, Novak $N^{2}$, Zaletel $K^{1}$, Pirnat $E^{1}$, Hojker $S^{1,2}$

${ }^{1}$ University Medical Centre Ljubljana, Ljubljana, Slovenia,

${ }^{2}$ Faculty of Medicine, University of Ljubljana, Ljubljana,

Slovenia

\section{P165 THYROID DISORDERS AND KIDNEY TRANSPLANTATION}

Gouveia $S^{1}$, Bastos $M^{1}$, Baptista $C^{1}$, Alves $R^{2}$, Ribeiro $C^{1}$, Vieira $A^{1}$, Alves $M^{1}$, Saraiva $J^{1}$, Moreno $C^{1}$, Mota $A^{3}$, Carvalheiro $M^{1}$, Carrilho $F^{1}$

${ }^{1}$ Coimbra's University Hospital, Endocrinology, Diabetes and Metabolism Department, Coimbra, Portugal, ${ }^{2}$ Coimbra's University Hospital, Nephrology Department, Coimbra, Portugal, ${ }^{3}$ Coimbra's University Hospital, Kidney

Transplantation and Urology Department, Coimbra, Portugal 
P166 AUTOIMMUNE THYROIDITIS IN PATIENTS WITH MULTIPLE SCLEROSIS TREATED WITH INTERFERON-BETA Nonchev $B^{1}$, Trenova $A^{2}$, Pavlov $P^{3}$, Manova $M^{2}$, Argatska $A^{1}$, Ginova-Noncheva $G^{4}$, Orbetzova $M^{1}$

${ }^{1}$ Medical University - Plovdiv, Endocrinology, Plovdiv, Bulgaria, ${ }^{2}$ Medical University - Plovdiv, Neurology, Plovdiv, Bulgaria, ${ }^{3}$ Medical University - Plovdiv, Central Clinical Laboratory, Plovdiv, Bulgaria, ${ }^{4}$ Medical University - Plovdiv, Nephrology, Plovdiv, Bulgaria

\section{P019 Hyperthyroidism 2 \\ Chair: Chantal Daumerie, Belgium}

\section{P167 YOUNGER AND LESS HYPERTHYROID PATIENTS} WITH GRAVES' DISEASE ARE MORE SUCCESSFULLY TREATED WITH THE FIRST DOSE OF RADIOIODINE

Pirnat $E^{1}$, Gaberšček $S^{1,2}$, Šfiligoj $D^{1}$, Jaki Mekjavič $P^{1,2}$, Zaletel $K^{1}$, Hojker $S^{1,2}$

${ }^{1}$ University Medical Centre Ljubljana, Ljubljana, Slovenia,

${ }^{2}$ Faculty of Medicine, University of Ljubljana, Ljubljana,

Slovenia

P168 INCREASING THE RADIOIODINE DOSE DOES NOT IMPROVE CURE RATES IN SEVERE GRAVES HYPERTHYROIDISM: A CLINICAL TRIAL WITH HISTORICAL CONTROL

Dora JM' ${ }^{1}$, Machado $W^{1}$, Andrade $V A^{1}$, Scheffel $R S^{1}$, Maia $A L^{1}$ ${ }^{1}$ Hospital de Clínicas de Porto Alegre, Thyroid Section, Porto Alegre, Brazil

\section{P169 EFFECTS OF THIAMAZOLE, METOPROLOL, AND} VITAMIN E ON OXIDATIVE STRESS IN GRAVES' DISEASE PATIENTS

Petrulea $\mathrm{MS}^{1}$, Muresan $\mathrm{A}^{2}$, Duncea $\mathrm{I}^{1}$

${ }^{1}$ Iuliu Hatieganu University of Medicine and Pharmacy Cluj-Napoca, Endocrinology, Cluj-Napoca, Romania, ${ }^{2}$ Iuliu Hatieganu University of Medicine and Pharmacy Cluj-Napoca, Physiology, Cluj-Napoca, Romania

P170 POTENTIAL CAPABILITIES OF MINIMALLY INVASIVE APPROACH IN THE SURGICAL TREATMENT OF GRAVES' DISEASE

Nenkov RN ${ }^{1}$, Radev RS ${ }^{1}$, Hristosov $K^{2}$

${ }^{1}$ Medical University of Varna, Thoracic Surgery, Varna, Bulgaria, ${ }^{2}$ Medical University of Varna, Clinic of Endocrinology, Varna, Bulgaria
P171 SUSTAINED INCREASE OF SERUM ADIPONECTIN FOLLOWING ADMINISTRATION OF RADIOIODINE IN TREATMENT OF THYROTOXICOSIS

Lewandowski $K^{1}$, Brona $A^{2}$, Karbownik-Lewińska $M^{3}$, Milewicz $A^{2}$,

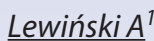

${ }^{1}$ The Medical University of Lodz, Department of Endocrinology and Metabolic Diseases, Lodz, Poland, ${ }^{2}$ The Medical University of Wroclaw, Department of Endocrinology, Diabetology and Isotope Therapy, Wroclaw, Poland, ${ }^{3}$ The Medical University of Lodz, Department of Oncological Endocrinology, Lodz, Poland

P172 THE TIME-LAG BETWEEN THE ONSET OF SYMPTOMS AND THE APPEARANCE OF ABNORMAL LABORATORY FINDINGS IN THE PATIENTS WITH SUBACUTE THYROIDITIS Tachibana $T^{1}$, Orita $Y^{2}$, Ogawara $Y^{1}$, Matsuyama $Y^{1}$, Abe I', Nishizaki $K^{2}$

${ }^{1}$ Himeji Red Cross Hospital, Otolaryngology, Himeji City, Japan, ${ }^{2}$ Okayama University, Otolaryngology-Head \& Neck Surgery,

Okayama City, Japan

\section{P173 GRAVES' DISEASE TREATMENT WITH FIXED} ACTIVITY OF RADIOIODINE

Sleptsov I' , Isheiskaya $M^{1}$, Chinchuk ${ }^{1}$, Chernikov $R^{1}$, Makarin $V^{1}$, Uspenskaya $A^{1}$, Semenov $A^{1}$, Novokshonov $K^{1}$, Bubnov $A^{1}$, Fedotov $Y^{1}$

${ }^{1}$ National Medical\&Surgical Center, Endocrine Surgery, St. Petersburg, Russian Federation

P174 A WEB-BASED CLINICAL TRIAL MANAGEMENT SYSTEM FOR A PRAGMATIC MULTI-CENTER TRIAL OF SELENIUM SUPPLEMENTATION VERSUS PLACEBO IN PATIENTS WITH GRAVES' DISEASE

Cramon $P^{1}$, Bue Bjorner $\mathrm{J}^{2}$, Joop Bonnema $S^{3}$, Feldt-Rasmussen $U^{1}$, Groenvold $M^{4}$, Hegedüs $L^{3}$, Holbech Nielsen $S^{5}$, Nauta Pedersen $A^{6}$, Krogh Rasmussen $\AA^{1}$, Watt $T^{1}$

${ }^{1}$ Copenhagen University Hospital - Rigshospitalet, Department of Medical Endocrinology, Copenhagen, Denmark, ${ }^{2}$ National Research Centre for the Working Environment, Copenhagen, Denmark, ${ }^{3}$ Odense University Hospital, Department of Endocrinology and Metabolism, Odense, Denmark, ${ }^{4}$ University of Copenhagen, Institute of Public Health Science, Copenhagen, Denmark, ${ }^{5}$ Admazely, Copenhagen, Denmark, ${ }^{6}$ Bitkompagniet, Copenhagen, Denmark

P175 THYROTROPIN-PRODUCING PITUITARY TUMOURS - A CHALLENGE FOR ENDOCRINOLOGIST AND NEUROSURGEON

Kostecka-Matyja $M^{1}$, Fedorowicz $A^{1}$, Hubalewska-Dydejczyk $A^{1}$

${ }^{1}$ Chair and Department of Endocrinology, Jagiellonian

University College of Medicine, Krakow, Poland 


\section{PO20 Hypothyroidism}

Chair: Marek Niedziela, Poland

P176 CHANGES IN T3 THERAPY RELATED QOL IN HYPOTHYROID PATIENTS IS NO SIGNIFICANTLY ASSOCIATED TO POLYMORPHISM IN DIO2, DIO1, MCT10, PDE8B OR SLC 16A10 GENES

Nygaard B ${ }^{1}$, Steffensen $R^{2}$, Faber $J^{1}$, Kvetney ${ }^{3}$, Jarloev $A^{4}$, Jensen $E W^{1}$, Laurberg $P^{5}$

${ }^{1}$ Herlev Hospital, University of Copenhagen, Dept of Endocrinology O 106, Herlev, Denmark, ${ }^{2}$ Aalborg University Hospital, Dept Clinical Immunology Aalborg, Aalborg, Denmark, ${ }^{3}$ Naestved Hospital, University of Southern Denmark, Dept Endocrinology, Naestved, Denmark, ${ }^{4}$ Frederiksberg Hospital, University of Copenhagen, Dept of Endocrinology, Frederiksberg, Denmark, ${ }^{5}$ Aalborg University Hospital, Dept of Endocrinology, Aalborg, Denmark

\section{P177 PREVALENCE OF HYPOTHYROIDISM AMONG} CHILDREN AND ADOLESCENTS WITH DIABETES MELLITUS Kiyaev $A^{1}$, Alexandrov $K^{1}$, Kovtun $O^{1}$

${ }^{1}$ Ural Medical Academy, Yekaterinburg, Russian Federation

\section{P178 THE INCIDENCE OF THYROID DYSFUNCTION IN}

\section{EUROPE: A META-ANALYSIS}

Garmendia Madariaga $A^{7}$, Guillén-Grima F², Galofré $\mathrm{JC}^{1}$

${ }^{1}$ Clínica Universidad de Navarra, Department of Endocrinology and Nutrition, Pamplona, Spain, ${ }^{2}$ Clínica Universidad de

Navarra, Department of Preventive Medicine, Pamplona, Spain

\section{P179 QUALITY OF LIFE AND EMOTIONAL STATUS OF PATIENTS WITH HYPOTHYROIDISM DUE TO RADIOIODINE TREATMENT OR SURGERY}

Dreval $A^{7}$, Nechaeva $\mathrm{O}^{1}$, Mamedova $^{\top}$, Shestakova $T^{1}$, Chikh ${ }^{1}$, Komerdous $I^{7}$

${ }^{1}$ Moscow Regional Research Clinical Institute, Moscow, Russian Federation
P180 COMPARATIVE EFFECTIVENESS OF REPLACEMENT THERAPY WITH L-THYROXINE IN WOMEN WITH POSTOPERATIVE AND AUTOIMMUNE HYPOTHYROIDISM Fadeyev $\mathrm{V}^{1,2}$, Madiyarova $\mathrm{M}^{1}$, Morgunova $T^{1}$

${ }^{1}$ I.M. Sechenov First Moscow State Medical University, Endocrinology, Moscow, Russian Federation, ${ }^{2}$ Federal Endocrinological Research Centre, Moscow, Russian Federation

P181 QUALITY OF LIFE AND THE PSYCHOEMOTIONAL STATUS OF THE PATIENTS WHO HAVE RECEIVED RADICAL TREATMENT OF GRAVES' DISEASE

Mamedova $T^{1}$, Dreval $A^{1}$, Nechaeva $O^{1}$, Shestakova $T^{1}$, Chikh I', Komerdous I 1

${ }^{1}$ Moscow Regional Research Clinical Institute, Moscow, Russian Federation

P182 THE QUALITY OF LIFE AND PSYCHO-EMOTIONAL STATUS OF PATIENTS WITH LOW AND UPPER-NORMAL LEVELS OF TSH

Dreval $A^{1}$, Nechaeva $\mathrm{O}^{1}$, Mamedova $T^{1}$, Chikh I ${ }^{1}$, Shestakova $T^{1}$, Komerdous $I^{1}$

${ }^{1}$ Moscow Regional Research Clinical Institute, Moscow, Russian Federation

\section{P183 SLEEP APNEA, MYOPATHY, HYPOTHYROIDISM:} CASE REPORT

Parhimovich $R M^{1}$, Chikh ID ${ }^{1}$, Zgulov DA ${ }^{2}$

${ }^{1}$ Moscow Regional Research Clinical Institute, Endocrinology, Moscow, Russian Federation, ${ }^{2}$ Moscow Regional Research Clinical Institute, Reanimatology, Moscow, Russian Federation 
Poster Exhibition Area

\subsection{0-13.00}

Poster Session 3

P021 Thyroid Cancer Diagnostics 3

Chair: Kalliopi Pazaitou-Panayiotou, Greece

P184 EARLY POSTOPERATIVE VOCAL FUNCTION EVALUATION AFTER THYROIDECTOMY USING THYROIDECTOMY RELATED VOICE QUESTIONNARE Chun B-J', Bae J-S', Chae B- $J^{2}$, Hwang $Y-S^{1}$, Shim M- $R^{1}$, Sun D-I'

${ }^{1}$ College of Medicine, The Catholic University of Korea, Department of Otolaryngology-Head and Neck Surgery, Seoul, Republic of Korea, ${ }^{2}$ College of Medicine, The Catholic University of Korea, Department of Surgery, Seoul, Republic of Korea

P185 HIGH THYROGLOBULIN LEVELS AT REMNANT ABLATION MAY PREDICT RECURRENT/PERSISTENT DISEASE IN DIFFERENTIATED THYROID CANCER(DTC) Aydoğan $B i^{1}$, Güllü $S^{1}$, Can $F^{1}$, Yüksel $B^{1}$, Özkan $E^{2}$, Emral $R^{1}$, Küçük Öं, Çorapçıoğlu $D^{1}$, Başkal $N^{1}$, Uysal $A R^{1}$, Erdogan $M F^{1}$ ${ }^{1}$ Ankara University School of Medicine, Endocrinology and Metabolism Diseases, Ankara, Turkey, ${ }^{2}$ Ankara University School of Medicine, Nuclear Medicine, Ankara, Turkey

\section{P186 REVIEW OF CLINICAL AND PATHOLOGICAL} FEATURES OF THYROID CARCINOMA FROM FOLLICULAR ORIGIN IN CHILDREN FROM SOUTH PORTUGAL REGIONAL CANCER REGISTRY BETWEEN 1964 AND 2006

Silva-Vieira $M^{1}$, Macedo $D^{1}$, Simões-Pereira $J^{1}$, Marques $P^{1}$, Santos $R^{1}$, Leite $V^{1}$, Limbert $E^{1}$

'Instituto Português de Oncologia de Lisboa, Francisco Gentil, Lisboa, Portugal
P187 OUR EXPERIENCES OF TRI-ANNUAL THYROID FINENEEDLE ASPIRATON BIOPSIES AT THE DOUBLE-HEAD CENTER IN AN ENDEMIC AREA: THE RETROSPECTIVE DESCRIPTIVE CYTOPATHOLOGICAL ANALYSIS OF 1196 CASES

Findık Guvendi $G^{1}$, Sengul $D^{2}$, Sengul ${ }^{3}$, Oksuz $H^{1}$, Guvendi $B^{4}$, Akgedik $S^{7}$, Maras Ozdemir $Z^{5}$, Erverdi $B^{5}$, Ozhan $C^{5}$, Gurgen $F^{5}$, Duzcu S $S^{5}$ Yilmaz ZC ${ }^{5}$

${ }^{1}$ The Ministery of Health, Prof. Dr. A. Ilhan Ozdemir State Hospital, Pathology, Giresun, Turkey, ${ }^{2}$ The Health Application and Research Center, Giresun University Faculty of Medicine, Pathology, Giresun, Turkey, ${ }^{3}$ The Health Application and Research Center, Giresun University Faculty of Medicine, General Surgery, Giresun, Turkey, ${ }^{4}$ The Ministery of Health, Prof. Dr. A. Ilhan Ozdemir State Hospital, General Surgery, Giresun, Turkey, ${ }^{5}$ The Ministery of Health, Prof. Dr. A. Ilhan Ozdemir State Hospital, Radiology, Giresun, Turkey

\section{P188 PREDICTION OF MALIGNANCY IN PATIENTS WITH SUSPICIOUS THYROID NODULE IN THE BACKGROUND OF HETEROGENEOUS PARENCHYMA \\ Nam $S Y^{1,2}$, Shin $J H^{1}$, Han $B-K^{1}, K o E Y^{1}, K o E S^{1}$, Hahn $S Y^{1}$ \\ ${ }^{1}$ Samsung Medical Center, Sungkyunkwan University School of Medicine, Radiology, Seoul, Korea, Republic of, ${ }^{2}$ Gil Hospital, Gachon University of Medicine and Science, Radiology, Incheon, Republic of Korea}

P189 ECHOGRAPHIC, CYTOLOGICAL AND HISTOLOGICAL CHARACTERISTICS OF THYROID FOLLICULAR TUMOR Gasparyan E', Goroshko $O^{2}$, Vorobyov $S^{1}$, Zaitseva $I^{1}$

${ }^{1}$ Medical Centre 'Professor', Endocrinology, Saint Petersburg, Russian Federation, ${ }^{2}$ Medical Centre 'Professor', Ultrasound Diagnostic, Saint Petersburg, Russian Federation

\section{P190 RETROSPECTIVE VALUE OF THE ECHOGRAPHIC PICTURE OF THYROID PAPILLARY CARCINOMA Zaitseva I', Gasparyan $E^{1}$, Goroshko $O^{2}$, Vorobyov $S^{1}$ \\ ${ }^{1}$ Medical Centre 'Professor', Endocrinology, Saint Petersburg, Russian Federation, ${ }^{2}$ Medical Centre 'Professor', Ultrasound Diagnostic, Saint Petersburg, Russian Federation}

P191 PAPILLARY THYROID CARCINOMA PRESENTING SPONGIFORM OR PREDOMINANTLY CYSTIC NODULE Kim SJ', Park $\mathrm{SH}^{1}$, Lee $\mathrm{SJ}^{1}$, Chung $\mathrm{B}^{1}$

${ }^{1}$ Chung-Ang University Hospital, Seoul, Republic of Korea 
P192 THYROID PAPILLARY CARCINOMA: ECHOGRAPHIC PICTURE

Goroshko ${ }^{1}$, Gasparyan $E^{2}$, Vorobyov $S^{2}$

${ }^{1}$ Medical Centre 'Professor', Ultrasound Diagnsotic,

Saint Petersburg, Russian Federation, ${ }^{2}$ Medical Academy of Postgraduate Studies, Endocrinology, Saint Petersburg, Russian Federation

\section{P022 Thyroid Cancer Diagnostics 4}

Chair: Valeriano Leite, Portugal

P193 THE IMPORTANT ROLE OF PREOPERATIVE ULTRASOUND AND CT FINDINGS OF THE PRIMARY TUMOR IN PREDICTING THE CERVICAL LYMPH NODE METASTASES OF PAPILLARY THYROID CARCINOMAS

Cho J-G ${ }^{1}$, Park M-W ${ }^{1}$, Baek S-K ${ }^{1}$, Kwon S- $Y^{1}$, Jung $K-Y^{1}$, Woo J-S ${ }^{1}$

${ }^{1}$ Korea University Medical College, Otorhinolaryngology-Head and Neck Surgery, Seoul, Republic of Korea

P194 PREOPERATIVE ULTRASOUND, FINE NEEDLE ASPIRATION CITOLOGY AND TG IN ASPIRATES IN THE ASSESSMENT OF LATERAL LYMPH NODES IN PATIENTS WITH PAPILLARY THYROID CARCINOMA

Sisko Markos I' , Franceschi $M^{1}$, Jukic $T^{1}$, Stanicic J',

Petranovic Ovcaricek $P^{1}$, Granic $R^{1}$, Punda $M^{1}$, Lukinac $L^{1}$, Kusic $Z^{1}$ ${ }^{1}$ University Hospital Center Sestre Milosrdnice, Department of Nuclear Medicine and Oncology, Zagreb, Croatia

P195 DIAGNOSIS OF THYROID NODULES BY MEANS OF FINE-NEEDLE ASPIRATION CYTOLOGY, RESEARCH RESULTS Dundua $T^{1}$, Javashvili $L^{1}$, Kaloiani $T^{2}$, Kherkheulidze $V^{1}$

${ }^{1}$ Clinic Cortex, Tbilisi, Georgia, ${ }^{2}$ National Centre of Oncology, Tbilisi, Georgia

P196 PREDICTORS OF MALIGNANCY IN THYROID NODULES WITH CYTOLOGICAL DIAGNOSIS OF FOLLICULAR NEOPLASM

Lim $\mathrm{JA}^{1}$, Lee $\mathrm{SH}^{2}$, Cho SY${ }^{3}$, Lee $\mathrm{TH}^{4}, \mathrm{Ku} \mathrm{YH}^{2}, \mathrm{Kim} \mathrm{H{ } ^ { 2 }}$, Kim MJ ${ }^{2}$

${ }^{1}$ Eulji University School of Medicine, Department of Internal Medicine, Seoul, Republic of Korea, ${ }^{2}$ Korea Cancer Center Hospital, Department of Internal Medicine, Seoul, Republic of Korea, ${ }^{3}$ Korea Cancer Center Hospital, Department of Pathology, Seoul, Republic of Korea, ${ }^{4}$ Korea Cancer Center Hospital, Department of Radiology, Seoul, Republic of Korea

P197 THYROID CANCER IN GRAVES' DISEASE PATIENTS

Chinchuk $I^{1}$, Sleptsov $I^{2}$, Isheiskaya $M^{1}$, Chernikov $R^{1}$, Semenov $A^{1}$, Makarin $V^{1}$, Novokshonov $K^{1}$, Uspenskaya $A^{1}$, Bubnov $A^{1}$,

Fedotov $Y^{1}$, Karelina $Y^{1}$

${ }^{1}$ National Medical \& Surgical Center, Endocrine Surgery,

St. Petersburg, Russian Federation, ${ }^{2}$ North-Western Regional Medical Center of Roszdrav, Endocrine Surgery, St. Petersburg, Russian Federation
P198 FALSE POSITIVE IODINE-131 SCAN IN A PATIENT WITH DIFFERENTIATED THYROID CARCINOMA AND CHRONIC INFLAMMATORY LUNGS DISEASE Oliveira $M J^{1}$, Babosa $L^{2}$, Povoa $A^{2}$, Soares $C^{2}$, Oliveira $J^{3}$ ${ }^{1}$ Centro Hospitalar de Vila Nova de Gaia / Espinho, EPE, Endocrinology, Porto, Portugal, ${ }^{2}$ Centro Hospitalar de Vila Nova de Gaia / Espinho, Surgery, Vila Nova Gaia, Portugal, ${ }^{3}$ HPP-MN, Nuclear Medicine, Porto, Portugal

P199 DIAGNOSIS OF PAPILLARY CANCER BY MEASUREMENT OF THYROGLOBULIN IN FINE NEEDLE ASPIRATES: CLINICAL CASES

Ribeiro $C^{1}$, Paiva $S^{1}$, Gouveia $S^{1}$, Melo $M^{1}$, Martins $M J^{2}$, Fernandes $G^{2}$, Leitão $F^{3}$, Carrilho $F^{1}$

${ }^{1}$ University Hospital of Coimbra, Endocrinology, Coimbra, Portugal, ${ }^{2}$ University Hospital of Coimbra, Pathology, Coimbra, Portugal, ${ }^{3}$ University Hospital of Coimbra, Clinical Pathology, Coimbra, Portugal

\section{P200 ANAPLASTIC CARCINOMA AND TOXIC} MULTINODULAR GOITER, AN UNUSUAL PRESENTATION Marcelino $M^{1}$, Marques $P^{2}$, Lopes $L^{1}$, Leite $V^{2}$, de Castro $J^{1}$ ${ }^{1}$ Armed Forces University Hospital, Endocrinology, Lisbon, Portugal, ${ }^{2}$ Portuguese Cancer Institute, Endocrinology, Lisbon, Portugal

\section{P201 REVIEW OF PAPILLARY THYROID CARCINOMA} VARIANTS: IMAGING, PATHOLOGICAL AND CLINICAL CORRELATION

Nam $S Y^{1,2}$, Shin $\mathrm{JH}^{1}$, Lee $\mathrm{JH}^{1}$

${ }^{1}$ Samsung Medical Center, Sungkyunkwan University School of Medicine, Radiology, Seoul, Korea, Republic of, ${ }^{2}$ Gil Hospital, Gachon University of Medicine and Science, Radiology, Incheon, Republic of Korea

\section{P023 Thyroid Cancer Therapeutics 3}

Chair: Françoise Borson-Chazot, France

\section{P202 BRAF ${ }^{\mathrm{V} 600 E}$ MUTATION IN PATIENTS WITH PAPILLARY} THYROID CARCINOMA CONCURRENT WITH HASHIMOTO THYROIDITIS

Kwak $H Y^{1}$, Choi $H^{1}$, Chae $B J^{1}$, Song $B J^{1}$, Jung $S S^{1}$, Bae JS ${ }^{1}$

${ }^{1}$ Catholic University of Korea, College of Medicine, Department of Surgery, Seoul, Republic of Korea 
P203 LONG TERM UTILITY OF INJECTION

LARYNGOPLASTY IN THE MANAGEMENT OF PERMANENT POST-THYROIDECTOMY VOCAL FOLD PARALYSIS PROSPECTIVE STUDY

Park KN ${ }^{1}$, Park $J H^{2}$, Kim JW ${ }^{3}$, Lee SW ${ }^{1}$

${ }^{1}$ Soonchunhyang University Hospital, Otorhinolaryngology and Head and Neck Surgery, Bucheon, Republic of Korea, ${ }^{2}$ Soonchunhyang University Hospital, Otorhinolaryngology and Head and Neck Surgery, Cheon An, Republic of Korea, ${ }^{3}$ Soonchunhyang University Hospital, Otorhinolaryngology and Head and Neck Surgery, Seoul, Republic of Korea

P204 SIALENDOSCOPY FOR DYSFUNCTIONS OF SALIVARY GLANDS AFTER RADIOACTIVE IODINE THERAPY

Choi J-S ${ }^{1}$, Lim J-Y $^{1}$, Kim Y-M ${ }^{1}$

${ }^{1}$ Inha University School of Medicine, Otorhinolaryngology-

Head and Neck Surgery, Incheon, Republic of Korea

P205 LEARNING CURVE FOR GASLESS ENDOSCOPIC THYROIDECTOMY USING THE TRANS-AXILLARY APPROACH: CUSUM ANALYSIS OF A SINGLE SURGEON'S EXPERIENCE

Kwak $H Y^{1}$, Choi $H^{1}$, Chae $B J^{1}$, Song $B J^{1}$, Jung $S S^{1}$, Bae JS $S^{1}$

${ }^{1}$ Catholic University of Korea, College of Medicine, Department of Surgery, Seoul, Republic of Korea

\section{P206 COMPARATIVE ANALYSIS OF THE CENTRAL NODE METASTASIS BETWEEN WITH OR WITHOUT CHRONIC LYMPHOCYTIC THYROIDITIS IN PAPILLARY THYROID CANCER \\ Son G-T ${ }^{1}$, Lee J-H $H^{1}$, Choi J-E' , Kang S-H $H^{1}$, Lee S-J1 \\ ${ }^{1}$ Yeungnam University College of Medicine, General Surgery, Daegu, Republic of Korea}

\section{P207 PROSPECTIVE STUDY ON SUTURELESS AND} DRAINLESS OPEN THYROIDECTOMY USING ULTRASONIC COAGULATOR: PRELIMINARY STUDY

Jeon $Y^{1}$

${ }^{1}$ Goo Hospital, Endocrine Surgery, Dae-Gu, Republic of Korea

P208 ROBOTIC THYROID SURGERY USING BILATERAL AXILLO-BREAST APPROACH: A SINGLE SURGEON'S EXPERIENCE AND OUTCOME WITH THE FIRST 200 CASES Kim WW ${ }^{1}$, Kang JG ${ }^{1}$, Choi $\mathrm{HH}^{1}$, Hwang $\mathrm{SO}^{1}$, Jung $\mathrm{JH}^{1}$, Park $H Y^{1}$ ${ }^{1}$ Kyungpook National University, Daegu, Republic of Korea

P209 COMPARISON STUDY BETWEEN HARMONIC FOCUS ${ }^{\circledR}$ AND LIGASURE ${ }^{\circledR}$ IN OPEN THYROIDECTOMY: A PROSPECTIVE, RANDOMIZED STUDY

Kim WW' ${ }^{1}$, Kang JG ${ }^{1}$, Choi $\mathrm{HH}^{1}$, Hwang SO ${ }^{1}$, Jung $\mathrm{JH}^{1}$, Park $\mathrm{HY}^{1}$ ${ }^{1}$ Kyungpook National University, Daegu, Republic of Korea
P210 SURGICAL SURVIVAL FIGURES FOR THYROID CANCER IN THE NORTHERN AND WEST YORKSHIRE REGIONS OF THE UNITED KINGDOM: IMPROVEMENTS AFTER TEN YEARS?

Flatley $\mathrm{MJ}^{1}$, Gerrard $\mathrm{G}^{1}$, Lawton $\mathrm{S}^{2}$, Aravani $\mathrm{A}^{2}$

${ }^{1}$ St James's University Hospital, Institute of Oncology, Leeds, United Kingdom, 2Public Health England (NYCRIS), St James's Institute of Oncology, Leeds, United Kingdom

\section{PO24 Thyroid Cancer Therapeutics 4}

Chair: Lionel Groussin, France

P211 TRANSORAL ENDOSCOPIC THYROIDECTOMY VIA THE TRI-VESTIBULAR ROUTE: RESULTS OF A PRECLINICAL CADAVER FEASIBILITY STUDY

Park J-O ${ }^{1}$, Cho $J-H^{1}$, Chun B-J', Sun D-I

${ }^{1}$ The Catholic University of Korea, Seoul, Republic of Korea

\section{P212 SHORTERM CHANGES OF ELECTROLYTES AND} PARATHYROID HORMONE IN PERMANENT HYPOCALCEMIA AFTER TOTAL THYORIDECTOMY IN PAPILLARY THYROID CANCER

Lee $\mathrm{K}-\mathrm{H}^{1}$, Cho $\mathrm{J}-\mathrm{H}^{1}$

${ }^{1}$ St. Vincent's Hospital, The Catholic University of Korea, Otolaryngology Head \& Neck Surgery, Suwon, Republic of Korea

P213 EXPERIENCE WITH THE USE OF RECOMBINANT HUMAN THYROTROPIN (RHTSH) IN FOLLOW-UP OF DIFFERENTIATED THYROID CARCINOMA AND THERAPY OF METASTATIC DISEASE

Mackova $M^{1}$, Vlcek $P^{1}$

${ }^{1}$ Motol University Hospital, Department of Nuclear Medicine and Endocrinology, Praha, Czech Republic

P214 HEMITHYROIDECTOMY IN PAPILLARY THYROID MICROCARCINOMA WITH THYROIDITIS INCREASES THE RISK OF POSTOPERATIVE HYPOTHYROIDISM

$\operatorname{Kim} Y^{1}$

${ }^{1}$ Ulsan University Hospital, Surgery, Ulsan, Republic of Korea

P215 UTILITY OF RECOMBINANT HUMAN TSH TO FACILITATE RADIO-IODINE UPTAKE BY LUNG METASTASES WHEN PITUITARY FAILS TO PRODUCE ENDOGENOUS TSH Dillikar $G^{1}$, Kumaresan $K^{1}$, Kavitha $N^{2}$

${ }^{1}$ KK Nuclear Scans, Hyderabad, India, ${ }^{2}$ Nizam's Institute of Medical Sciences, Nuclear Medicine, Hyderabad, India 
P216 VISUAL AND QUANTITATIVE EVALUATION OF POSTOPERATIVE RADIOIODINE ABLATION WITH I-131 WITH 1850MBQ IN PATIENTS WITH DIFFERENTIATED THYROID CANCER

Kawabe $J^{1}$, Higashiyama $S^{1}$, Kotani $K^{1}$, Yoshida $A^{1}$, Onoda $N^{2}$, Shiomi $S^{1}$

${ }^{1}$ Graduate School of Medicine, Osaka City University, Department of Nuclear Medicine, Osaka City, Japan, ${ }^{2}$ Graduate School of Medicine, Osaka City University, Department of Surgical Oncology, Osaka City, Japan

P217 THE CLINICAL FEATURES IN PATIENTS WITH POORLY DIFFERENTIATED THYROID CARCINOMA Kim YS ${ }^{1}$

${ }^{1}$ Ulsan University Hospital, Surgery, Ulsan, Republic of Korea

P218 THYROID CANCER RATE IN PATIENTS WHO UNDERWENT TOTAL THYROIDECTOMY WITH THE DIAGNOSIS OF TNG

$\underline{\operatorname{Tam} A A^{1}}$, Kaya $C^{1}$, Kıyak $G^{2}$, Ersoy $P E^{2}$, Yalçın $S^{3}$, Yıldırım Poyraz $N^{4}$, Kılıcyazgan $A^{5}$, Guler $G^{5}$, Ersoy $R^{6}$, Cakır $B^{6}$ ${ }^{1}$ Ataturk Education and Research Hospital, Department of Endocrinology and Metabolism, Ankara, Turkey, ${ }^{2}$ Ataturk Education and Research Hospital, Department of General Surgery, Ankara, Turkey, ${ }^{3}$ Yıldırım Beyazıt University Faculty of Medicine, Department of General Surgery, Ankara, Turkey, ${ }^{4}$ Ataturk Education and Research Hospital, Department of Nuclear Medicine, Ankara, Turkey, ${ }^{5}$ Y Ildırım Beyazıt University Faculty of Medicine, Department of Pathology, Ankara, Turkey, ${ }^{6}$ Yıldırım Beyazıt University Faculty of Medicine, Department of Endocrinology and Metabolism, Ankara, Turkey

\section{P025 Case Reports 3}

Chair: Valentin Fadayev, Russia

\section{P219 COMBINED THYROID DYSFUNCTION IN PATIENTS WITH ACROMEGALY}

llovaiskaja I', Dreval $A^{1}$, Shestakova $T^{1}$

${ }^{1}$ Moscow Regional Research Clinical Institute

n.M.F Vladimirskii, Endocrinology, Moscow, Russian Federation

\section{P220 Poster has been withdrawn}

\section{P221 MASSIVE PERICARDIAL EFFUSION: MYXEDEMA OR} SOMETHING MORE?

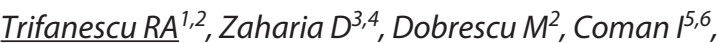
Bogdan $M A^{3,4}$, Poiana $\mathrm{C}^{1,2}$

${ }^{1}$ Carol Davila University of Medicine and Pharmacy, Endocrinology Dept., Bucharest, Romania, ${ }^{2}$ C.I. Parhon National Institute of Endocrinology, Bucharest, Romania, ${ }^{3}$ Carol Davila University of Medicine and Pharmacy, Pneumology Dept., Bucharest, Romania, ${ }^{4}$ Marius Nasta Institute of Pneumology, Bucharest, Romania, ${ }^{5}$ Carol Davila University of Medicine and Pharmacy, Cardiology Dept., Bucharest, Romania, ${ }^{6}$ C.C. Iliescu Institute of Cardiology, Bucharest, Romania
P222 ALOPECIA AREATA AFTER RADIOIODINE TREATMENT OF BONE METASTASES FROM THYROID FOLLICULAR CARCINOMAS

Begolli $A G^{1}$, Gerqari $1^{2}$, Rizvanolli $N^{3}$, Miftari $R^{4}$, Ferizi $M^{1}$, Halimi $S^{5}$, $\operatorname{Daka}^{1}$

${ }^{1}$ University Clinical Center of Kosovo, Dermatovenerologic Clinic, Pristina, Albania, ${ }^{2}$ University Clinical Center of Kosovo, Nuclear Medicine Service \& Diagnostika plus, Pristina, Albania, ${ }^{3}$ Diagnostika plus, Nuclear Medicine Service \& Diagnostika plus, Pristina, Albania, ${ }^{4}$ University Clinical Center of Kosovo, Nuclear Medicine Service, Pristina, Albania, ${ }^{5}$ Univrsity Clinical Center of Kosovo, Dermatovenerologic Clinic, Pristina, Albania

P223 THYROTROPIN SECRETING ADENOMA AND THYROID HORMONE RESISTANCE: TWO CASES Algun $E^{1}$, Anaforoglu I ${ }^{1}$, Kose $\mathrm{M}^{1}$, Incecayır $\mathrm{O}^{1}$

${ }^{1}$ Trabzon Kanuni Education and Research Hospital, Endocrinology and Metabolism, Trabzon, Turkey

P224 FAMILIAL PAPILLARY THYROID CARCINOMA: AGGRESSIVE TREATMENT OR CAREFUL SURVEILLANCE?

Siddiqi $A I^{1}$, Chung $T^{1}$

${ }^{1}$ University College London Hospitals, Diabetes and

Endocrinology, London, United Kingdom

P225 VANISHING BRAIN METASTASES FOLLOWING RADIO-IODINE THERAPY IN I-131 SCAN AS WELL AS IN MAGNETIC RESONANCE IMAGING - A RARE OCCURRENCE Zakir Ali $A^{1}$, Kumaresan $K^{2}$

${ }^{1}$ Basavatarakam Indo-American Cancer Institute, Nuclear Medicine, Hyderabad, India, ${ }^{2}$ KK Nuclear Scans, Hyderabad, India

\section{P226 AUTOIMMUNE HYPO TO HYPERTHYROIDISM,} A RARE EVOLUTION

Marcelino $\mathrm{M}^{1}$, Silva $\mathrm{J}^{1}$, Passos $\mathrm{D}^{1}$, de Castro $\mathrm{J}^{1}$

${ }^{1}$ Armed Forces University Hospital, Endocrinology, Lisbon, Portugal

\section{P227 CLINICAL CASE - RADIOTHERAPY IN ENDOCRINE OPHTHALMOPATHY}

Luchina $E^{1}$, Lukashova $M^{1}$, Meleshkevich $T^{1}$

${ }^{1}$ Central Clinical Hospital \#2 n.a. N.A. Semashko Public Corporation 'Russian Railways', Endocrinology, Moscow, Russian Federation 
P026 Imaging

Chair: Markus Luster, Germany

P228 ID01 (INDOLEAMINE-2,3-DIOXYGENASE 1) INHIBITION DECREASES PROLIFERATION OF FOLLICULAR THYROID CARCINOMA-DERIVED FTC133 CELLS: IN VITRO AND IN VIVO DATA

Moretti $S^{1}$, Menicali $E^{1}$, Voce $P^{1}$, Puxeddu $E^{1}$

${ }^{1}$ University of Perugia, Internal Medicine, Perugia, Italy

P229 FDG POSITIVE, IODINE NEGATIVE PATIENTS ARE STRONGLY ASSOCIATED WITH A POSITIVE TG DOUBLING TIME, HOWEVER, THE 'FLIP-FLOP' PHENOMENON IN DIFFERENTIATED THYROID CARCINOMA IS OFTEN INCOMPLETE

Kelders $A^{1}$, Kennes $L^{2}$, Krohn $T^{1}$, Behrendt $F^{1}$, Mottaghy $F^{1}$, Verburg $F A^{7}$

${ }^{1}$ University Hospital Aachen, Nuclear Medicine, Aachen, Germany, ${ }^{2}$ University Hospital Aachen, Medical Statistic, Aachen, Germany

\section{P230 ACCURACY AND OBSERVER VARIATION OF THE} ASSESSMENT OF THYROID RADIOIODINE UPTAKE AND GOITER SIZE BY VISUAL INTERPRETATION OF THYROID SCINTIGRAMS

Soelberg $K K^{1}$, Grupe $P^{2}$, Jørgensen $H B^{3}$, Jørgensen $\mathrm{PH}^{4}$, Fast $\mathrm{S}^{1}$, Nielsen $V E^{1}$, Hegedüs $L^{1}$, Bonnema $S^{\prime}$

'Odense University Hospital, Endocrinology, Odense, Denmark, ${ }^{2}$ Odense University Hospital, Nuclear Medicine, Odense, Denmark, ${ }^{3}$ Sygehus Lillebælt, Nuclear Medicine, Vejle, Denmark, ${ }^{4}$ Odense University Hospital, Cardiology, Odense, Denmark

\section{P231 METASTASES TO THE THYROID GLAND; US CLASSIFICATION ACCORDING TO ORIGINAL MALIGNANCIES}

Lee $K H^{1}$, Shin $J H^{2}$, Han $B-K^{2}, K o E Y^{2}$

'Inje University Haeundae Paik Hospital, Radiology, Busan, Republic of Korea, ${ }^{2}$ Samsung Medical Center, Sungkyunkwan University School of Medicine, Radiology, Seoul, Republic of Korea

\section{P232 Poster has been withdrawn}

\section{P233 PRINCIPLES OF PROPER APPLICATION OF} ULTRASOUND (US) AND A FINE-NEEDLE ASPIRATION BIOPSY (FNAB) IN PATIENTS WITH NODULES/US FOCAL LESIONS OF THE THYROID GLAND

Lewiński $A^{1,2}$, Adamczewski $Z^{1,2}$

${ }^{1}$ The Medical University of Lodz, Department of Endocrinology and Metabolic Diseases, Lodz, Poland, ${ }^{2}$ Polish Mother's Memorial Hospital - Research Institute, Lodz, Poland
P234 GRAY SCALE ULTRASONOGRAPHY IN DETECTING NEOPLASTIC THYROID NODULES. IS IT USEFUL? Aslan $A^{1,2}$, Sancak S ${ }^{3,4}$, Aslan $M^{2,5}$, Buğdaycı $O^{6}$, Güllüoğlu $B^{7}$, Ahıskalı RA ${ }^{8}$, Akalın NS ${ }^{4}$, Arıbal ME ${ }^{2}$

${ }^{1}$ Şevket Yılmaz Educational Hospital, Department of Radiology, Bursa, Turkey, ${ }^{2}$ Marmara Medical School, Department of Radiology, Istanbul, Turkey, ${ }^{3}$ Fatih Sultan Mehmet Educational Hospital, Section of Endocrinology and Metabolism, Istanbul, Turkey, ${ }^{4}$ Marmara Medical School, Department of Endocrinology and Metabolism, Istanbul, Turkey, ${ }^{5}$ Zübeyde Hanım Doğumevi, Department of Radiology, Bursa, Turkey, ${ }^{6}$ inebolu State Hospital, Department of Radiology, Kastamonu, Turkey, ${ }^{7}$ Marmara Medical School, General Surgery Department, Istanbul, Turkey, ${ }^{8}$ Marmara Medical School, Department of Pathology, Istanbul, Turkey

\section{P235 131 I SPECT/CT FALSE POSITIVE IMAGES IN DIFFERENTIATED THYROID CANCER, OR HOW TO DISTINGUISH BETWEEN PHYSIOLOGICAL AND} PATHOLOGICAL UPTAKE? ON BEHALF OF THE FRENCH TUTHYREF (TUMEURS DE LA THYROIDE REFRACTAIRES) NETWORK

Méas $T^{1}$, Godbert $Y^{2}$, Kelly $A^{3}$, Schvartz $C^{4}$, Ciappuccini $R^{5}$, Faugeron $I^{1}$, Toubert $M-E^{1}$

${ }^{1}$ Saint-Louis Hospital, APHP, Nuclear Medicine, Paris, France, ${ }^{2}$ Institut Bergonie, Nuclear Medicine, Bordeaux, France, ${ }^{3}$ Centre Jean Perrin, Nuclear Medicine, Clermont-Ferrand, France, ${ }^{4}$ Centre Jean Godinot, Nuclear Medicine, Reims, France, ${ }^{5}$ Centre François Baclesse, Nuclear Medicine, Caen, France

\section{P236 ULTRASOUND RISK STRATIFICATION OF THYROID} FOLLICULAR NEOPLASMS

Russ $G^{1,2}$, Royer $B^{2,3}$, Bigorgne $C^{2}$, Rouxel $A^{1,2}$, Bienvenu-Perrard $M^{2,4}$, Leenhardt $L^{1,5}$

${ }^{1}$ Pitié-Salpêtrière Hospital, Nuclear Medicine, Paris, France, ${ }^{2}$ Centre de Pathologie et d'Imagerie, Paris, France, ${ }^{3}$ Cochin Hospital, Pathology, Paris, France, ${ }^{4}$ Cochin Hospital, Nuclear Medicine, Paris, France, ${ }^{5}$ Pierre et Marie Curie University, Paris, France

\section{P237 NON-DIAGNOSTIC RESULTS OF FINE NEEDLE} ASPIRATION CYTOLOGY OF THYROID NODULES

Jacobs $S^{1}$, van Nederveen $F^{2}$, Burger $P^{2}$, Peeters $R^{2}$, Vernooij $M^{2}$, van der Lugt $A^{2}$

${ }^{1}$ Erasmus Medical Center, Radiology, Rotterdam, Netherlands,

${ }^{2}$ Erasmus Medical Center, Rotterdam, Netherlands 
P027 Thyroid Hormone Metabolism and Action Chair: Maria Jesus Obregòn, Spain

\section{P238 HISTOPATHOLOGICAL ANALYSIS OF} MCT8-DEFICIENT HUMAN BRAINS

Lopez-Espindola $D^{1,2}$, Morales-Bastos $C^{3}$, Refetoff $S^{4}$, Lev $D^{5}$, Sugo $E^{6}$, Bernal $J^{1,7}$, Guadaño-Ferraz $A^{1}$

${ }^{1}$ Instituto de Investigaciones Biomédicas (CSIC-UAM), Madrid, Spain, ${ }^{2}$ Universidad de Valparaiso, Valparaiso, Chile, ${ }^{3}$ La Paz University Hospital, Madrid, Spain, ${ }^{4}$ University of Chicago, Chicago, United States, ${ }^{5}$ Wolfson Medical Center, Holon, Israel, ${ }^{6}$ Prince of Wales Hospital, Randwick, Australia, ${ }^{7} \mathrm{CIBERER}$, Madrid, Spain

P239 ALTERED THYROID HORMONE METABOLISM IN THE PREMATURELY AGING KLOTHO MUTANT MICE

Doycheva $D^{1}$, Laubscher $U^{1}$, Darras VM², Boelen $A^{3}$, Zevenbergen $C^{4}$, Visser $W E^{4}$, Visser $T J^{4}$, Kuro-o $M^{5}$, Kaether $C^{1}$, Heuer $\mathrm{H}^{1}$

${ }^{1}$ Leibniz Institute for Age Research/Fritz Lipmann Institute, Jena, Germany, ${ }^{2} \mathrm{KU}$ Leuven, Leuven, Belgium, ${ }^{3}$ Academical Medical Centre, Amsterdam, Netherlands, ${ }^{4}$ Erasmus Medical Center, Rotterdam, Netherlands, ${ }^{5}$ The University of Texas Southwestern Medical Center, Dallas, United States

\section{P240 TSH EFFECTS ON THERMOGENESIS IN RAT BROWN ADIPOCYTES}

Martinez-de-Mena $R^{1}$, Anedda $A^{2}$, Cadenas $S^{2}$, Obregon $M-J^{1}$ ${ }^{1} \mathrm{CSIC}$, Fisiopatologia Endocrina, Madrid, Spain, ${ }^{2}$ Hospital de la Princesa, Madrid, Spain

\section{P241 SIMULTANEOUS ANALYSIS OF ALL NINE POSSIBLE IODOTHYRONINES BY LIQUID CHROMATOGRAPHY- TANDEM MASS SPECTROMETRY}

Köhrle J', Martin $\mathrm{C}^{2}$, Renko $K^{1}, \underline{\text { Hoefig }}$ CS $^{1,3}$

${ }^{1}$ Charité-Universitätsmedizin Berlin, Institut für experimentelle Endokrinologie, Berlin, Germany, ${ }^{2}$ Waters GmbH, Eschborn, Germany, ${ }^{3}$ Karolinska Institute, Department of Cell \& Molecular Biology, Stockholm, Sweden

\section{P242 DIVERSE ASPECTS OF 3-T1AM INDUCED SIGNALING} AT HUMAN AND MOUSE TRACE AMINE-ASSOCIATED RECEPTOR 5 (TAAR5)

Mühlhaus J' ${ }^{1}$, Pratzka J', Piechowski $\mathrm{CL}^{1}$, Krude $\mathrm{H}^{1}$, Grüters-Kieslich $A^{1}$, Köhrle $\mathcal{J}^{2}$, Kleinau $G^{1}$, Biebermann $H^{1}$ ${ }^{1}$ Charité Universitätsmedizin Campus Virchow-Klinikum, Institute for Experimental Pediatric Endocrinology, Berlin, Germany, ${ }^{2}$ Charité Universitätsmedizin Campus VirchowKlinikum, Institute for Experimental Endocrinology, Berlin, Germany
P243 TISSUE-SPECIFIC FUNCTION OF THE MURINE THYROID HORMONE TRANSPORTER MCT8 Horn $S^{1}$, Müller $J^{1}$, Liebsch $C^{1}$, Visser $T J^{2}$, Heuer $H^{1}$ ${ }^{1}$ Leibniz Institute for Age Research / Fritz Lipmann Institute (FLI), Jena, Germany, ${ }^{2}$ Erasmus Medical Center, Erasmus University, Internal Medicine, Rotterdam, Netherlands

\section{P244 TRANSCRIPTIONAL ACTIVITY OF A TRE IN THE} HUMAN KLF9 PROMOTER

Moeller $L C^{1}$, Saygün $G^{1}$, Jaeger $A^{1}$, Führer $D^{1}$

${ }^{1}$ University Duisburg-Essen, Endocrinology and Metabolism, Essen, Germany

\section{P245 A NOVEL HPLC-MS-MS METHOD TO ASSAY TISSUE} THYROID HORMONES

Saba $A^{1}$, Colligiani $D^{1}$, Donzelli $R^{1}$, Chiellini $G^{1}$, Nannipieri $M^{1}$, Kusmic $C^{2}$, Dos Remedios $C^{3}$, Simonides $W^{4}$, lervasi $G^{2}, Z$ ucchi $R^{1}$ ${ }^{1}$ University of Pisa, Pisa, Italy, ${ }^{2}$ CNR Institute of Clinical Physiology, Pisa, Italy, ${ }^{3}$ University of Sydney, Sydney, Australia, ${ }^{4}$ VU University Medical Center, Amsterdam, Netherlands

\section{P246 ESTABLISHMENT OF A COMPETITIVE} CHEMILUMINESCENCE IMMUNOASSAY TO DETECT 3,5-DIIODO-L-THYRONINE IN HUMAN SERUM Lehmphul I', Wu $Z^{2}$, Strasburger $C \mathcal{J}^{2}$, Köhrle $\mathrm{J}^{1}$ ${ }^{1}$ Charité - Universitätsmedizin Berlin, Institut für Experimentelle Endokrinologie, Berlin, Germany, ${ }^{2}$ Charité Universitätsmedizin Berlin, Department of Medicine for Endocrinology, Diabetes and Nutritional Medicine, Berlin, Germany

\section{P247 EXPRESSION AND LOCALIZATION OF TRACE} AMINE-ASSOCIATED RECEPTORS IN RODENT THYROID EPITHELIAL CELLS WITH ALTERED ACTIVITIES OF THE THYROGLOBULIN-PROCESSING CYSTEINE CATHEPSINS B, K, AND L

Qatato $M^{1}$, Szumska $J^{1}$, Venugopalan $V^{1}$, Rehders $M^{1}$, Mc Innes $J^{1}$, Oellrich $N^{1}$, Pratzka ${ }^{2}$, Saftig $P^{3}$, Peters $C^{4}$, Reinheckel $T^{4}$,

Führer $D^{5}$, Biebermann $H^{2}$, Brix $K^{1}$

${ }^{1}$ Jacobs University Bremen, School of Engineering and Science, Bremen, Germany, ${ }^{2}$ Charité - Universitätsmedizin Berlin, Institut für Experimentelle Pädiatrische Endokrinologie, Berlin, Germany, ${ }^{3}$ Christian-Albrechts Universität zu Kiel, Institute of Biochemistry, Kiel, Germany, ${ }^{4}$ Albert-Ludwigs-Universität Freiburg, Institut für Molekulare Medizin und Zellforschung, Freiburg, Germany, ${ }^{5}$ Universitätsklinikum Essen, Klinik für Endokrinologie und Stoffwechselerkrankungen, Essen, Germany

P248 HOMOLOGY MODEL OF THE L-TYPE AMINO ACID TRANSPORTER LAT2 FOR ELUCIDATING THE STRUCTUREFUNCTION RELATIONSHIPS OF SUBSTRATE TRANSPORT Hinz $K^{1}$, Kinne $A^{1}$, Krause $G^{1}$

${ }^{1}$ Leibniz-Institut für Molekulare Pharmakologie, Berlin, Germany 
P249 COLLECTING MULTIPLE URINARY IODINE CONCENTRATION SAMPLES FROM EACH PARTICIPANT IN POPULATION SURVEYS - IS IT WORTH IT?

Samidurai $A J^{1}$, Davies PSW' ${ }^{1}$, Ware $R S^{2,3}$

${ }^{1}$ Childrens Nutrition Research Centre, Queensland Children's Medical Research Institute, The University of Queensland, Brisbane, Australia, ${ }^{2}$ Queensland Children's Medical Research Institute, The University of Queensland, Brisbane, Australia, ${ }^{3}$ School of Population Health, The University of Queensland, Brisbane, Australia

\section{P028 Medullary Thyroid Cancer \\ Chair: Laura Fugazzola, Italy}

\section{P250 WHOLE EXOME SEQUENCING OF MEDULLARY} THYROID CARCINOMA CASES IDENTIFIES 86 VARIATIONS IN GENES POSSIBLY INVOLVED IN TUMORAL

\section{TRANFORMATION}

Ciampi $R^{1}$, Lami $P^{1}$, Romei $C^{1}$, Tacito $A^{1}$, Vivaldi $A^{1}$, Vitti $P^{1}$, Elisei $R^{1}$

${ }^{1}$ Pisa, Department of Clinical and Experimental Medicine, Pisa, Italy

\section{P251 LESS CANCER REOPERATIONS AFTER INITIAL SURGERY ACCORDING TO ATA GUIDELINES IN MEDULLARY THYROID CANCER}

Verbeek $H H G^{1}$, Meijer JAA ${ }^{2,3}$, Zandee $W T^{3}$, Kramp $K H^{1}$, Sluiter $W J^{1}$, Smit JW ${ }^{3,4}$, Kieivt $J^{5}$, Links TP ${ }^{1}$, Plukker JTM ${ }^{6}$

${ }^{1}$ University of Groningen, University Medical Center Groningen, Department of Endocrinology, Groningen, Netherlands, ${ }^{2}$ Albert Schweitzer Hospital, Internal Medicine, Dordrecht, Netherlands, ${ }^{3}$ Leiden University Medical Center, Department of Endocrinology, Leiden, Netherlands, ${ }^{4}$ Radboud University Nijmegen Medical Center, Department of Internal Medicine, Nijmegen, Netherlands, ${ }^{5}$ Leiden University Medical Center, Department of Surgery, Leiden, Netherlands, ${ }^{6}$ University of Groningen, University Medical Center Groningen, Department of Surgical Oncology, Groningen, Netherlands

\section{P252 ANTI-NEOPLASTIC ACTIVITY OF CLM3 AND CLM94, MULTI-TARGET PYRAZOLOPYRIMIDINE DERIVATES, IN MEDULLARY THYROID CANCER IN VITRO}

Fallahi $P^{1}$, Ferrari $S M^{1}$, La Motta $C^{1}$, Di Domenicantonio $A^{1}$, Mancusi $C^{1}$, Materazzi $G^{1}$, Galleri $D^{1}$, Da Settimo $F^{1}$, Miccoli $P^{1}$, Antonelli $A^{1}$

${ }^{1}$ University of Pisa, Pisa, Italy
P253 COMBINED TREATMENT WITH EVEROLIMUS AND 5-AZA-2' -DEOXYCYTIDINE: A NEW THERAPEUTIC STRATEGY IN MEDULLARY THYROID CANCER

Dicitore $A^{1}$, Gaudenzi $G^{2}$, Caraglia $M^{3}$, Misso $G^{3}$, Borghi $M^{2,4}$, Hofland $L^{5}$, Persani $L^{1,2}$, Vitale $G^{1,2}$

${ }^{1}$ Istituto Auxologico Italiano, Laboratory of Endocrine and Metabolic Research, Cusano Milanino, Italy, ${ }^{2}$ University of Milan, Department of Clinical Sciences and Community Health, Milan, Italy, ${ }^{3}$ Second University of Naples, Department of Biochemistry, Biophysics and General Pathology, Naples, Italy, ${ }^{4}$ Istituto Auxologico Italiano, Laboratory of Immunology, Cusano Milanino, Italy, ${ }^{5}$ Erasmus MC, Department of Internal Medicine, Division of Endocrinology, Rotterdam, Netherlands

\section{P254 TIMING OF TOTAL THYROIDECTOMY IN RET GENE} CARRIERS $<18$ YEARS OF AGE

Romei $C^{1}$, Bottici $V^{1}$, Opocher $G^{2}$, Mian $C^{2}$, Brandi $M L^{3}$, Giusti $F^{3}$, Loli $P^{4}$, Castellano $M^{5}$, Cappelli $C^{5}$, Persani $L^{6}$, Filetti $S^{7}$, Fugazzola $L^{6}$, Verga $U^{6}$, degli Uberti $E^{8}$, Zatelli $M C^{8}, \mathrm{Colao}^{9}$, Faggiano $A^{9}$, Creminini $N^{10}$, Taccaliti $A^{11}$, Boscaro $M^{11}$, Giorgino $F^{12}$, Orlandi $F^{13}$, Elisei $R^{1}$, ItaMEN network ${ }^{1}$ University of Pisa, Section of Endocrinology, Department of Clinical and Experimental Medicine, Pisa, Italy, ${ }^{2}$ Dept. of Medicine-DIMED, University of Padua, Padua, Italy, ${ }^{3}$ Unit of Metabolic Bone Diseases, Department of Surgery and Translational Medicine, University of Florence, Florence, Italy, ${ }^{4}$ Dept of Medical Specialties, Endocrinology Unit, Ospedale Niguarda Cà Granda, Milano, Italy, ${ }^{5}$ Dept of Clinical and Experimental Sciences, Internal Medicine and Endocrinology Unit, University of Brescia, Brescia, Italy, ${ }^{6}$ Dept. of Clinical Sciences and Community Health, University of Milan, Milan, Italy, ${ }^{7}$ Department of Internal Medicine and Medical Specialties, University of Rome 'Sapienza', Rome, Italy, ${ }^{8}$ Dept of Medical Sciences, University of Ferrara, Ferrara, Italy, ${ }^{9}$ Dept of Clinical Medicine and Surgery, 'Federico II' University of Naples, Naples, Italy, ${ }^{10}$ Endocrinology Unit - Maggiore Hospital - Bologna, Bologna, Italy, ${ }^{11}$ Dept. of Clinical and Molecular Science, Polytecnic University of Marche, Ancona, Italy, ${ }^{12}$ Dept of Emergenza e Trapianto di Organi, University of Bari, Bari, Italy, ${ }^{13}$ Dept of Oncology, University of Turin, Turin, Italy

\section{P255 CLINICAL CHARACTERISTICS IN SPORADIC AND FAMILIAL MEDULLARY THYROID CARCINOMAS (MTCS) AT PRESENTATION ARE CURRENTLY SIMILAR}

Alevizaki $M^{1}$, Saltiki $K^{1}$, Rentziou $G^{1}$, Athanasiadou $A^{1}$, Kyratzoglou $E^{1}$, Sarika $L^{1}$, Anastasiou $E^{1}$

${ }^{1}$ Athens University School of Medicine, Endocrine Unit, Dept Medical Therapeutics, Athens, Greece

\section{P256 RETROSPECTIVE ANALYSIS OF 140 CASES OF MEDULLARY THYROID CARCINOMA IN A SINGLE INSTITUTION}

Simões-Pereira J' ${ }^{1}$ Silva Vieira $M^{2}$, Macedo $D^{2}$, Marques $P^{2}$, Moura $M^{2}$, Limbert $E^{2}$, Bugalho $\mathrm{MJ}^{2}$, Leite $V^{2}$

${ }^{1}$ Instituto Português de Oncologia de Lisboa Francisco Gentil, Endocrinology, Lisbon, Portugal, ${ }^{2}$ Instituto Português de Oncologia de Lisboa Francisco Gentil, Lisbon, Portugal 
P257 TWO GENETIC VARIANT IN THE 3'UTR OF THE RET PROTO-ONCOGENE ARE IN LINKAGE DISEQUILIBRIUM WITH S836S POLYMORPHISM IN PATIENTS WITH MEDULLARY THYROID CARCINOMA

Ceolin $L^{1}$, Siqueira $D R^{1}$, Romitti $M^{1}$, Ferreira $C V^{1}$, Maia $A L^{1}$

${ }^{1}$ Universidade Federal do Rio Grande do Sul, Endocrinology, Porto Alegre, Brazil

\section{P258 Poster has been withdrawn}

\section{PO29 Thyroid Nodules and Goitre 2 Chair: Ralf Paschke, Germany}

\section{P259 SOMATIC MUTATIONS IN 33 HOT THYROID NODULES IN CHILDREN}

Eszlinger $M^{1}$, Niedziela $M^{2}$, Typlt $E^{1}$, Huth $S^{1}$, Jäschke $H^{1}$, Schaarschmidt $J^{1}$, Krohn $K^{3}$, Paschke $R^{1}$

${ }^{1}$ Universität Leipzig, Klinik \& Poliklinik für Endokrinologie und Nephrologie, Leipzig, Germany, ${ }^{2}$ Poznan University of Medical Sciences, Department of Pediatric Endocrinology and Rheumatology, Poznan, Poland, ${ }^{3}$ Universität Leipzig, IZKF Leipzig, Leipzig, Germany

\section{P260 RARE ALLELE OF RS944289 AT CHROMOSOME 14Q13.3 ASSOCIATES WITH RISK OF BOTH MALIGNANT AND BENIGN THYROID TUMORS IN JAPANESE POPULATION}

Rogounovitch $T^{1}$, Saenko VA², Bychkov $A^{1}$, Nikitski AV ${ }^{1}$ Takahashi $M^{3}$, Nakashima $M^{4}$, Hayashi $T^{5}$, Hirokawa $M^{6}$, Miyauchi $A^{6}$, Shigematsu $K^{7}$, Mitsutake $N^{1}$, Matsuda $F^{3}$, Yamashita $S^{1,2}$

${ }^{1}$ Nagasaki University, Department of Radiation Medical Sciences, Nagasaki, Japan, ${ }^{2}$ Nagasaki University, Department of Health Risk Control, Nagasaki, Japan, ${ }^{3}$ Kyoto University Graduate School of Medicine, Center for Genomic Medicine, Kyoto, Japan, ${ }^{4}$ Nagasaki University, Department of Tumour and Diagnostic Pathology, Nagasaki, Japan, ${ }^{5}$ Nagasaki University Hospital, Department of Pathology, Nagasaki, Japan, ${ }^{6}$ Kuma Hospital, Kobe, Japan, ${ }^{7}$ Japanese Red Cross Nagasaki Genbaku Hospital, Department of Pathology, Nagasaki, Japan
P261 SYSTEMIC OXIDATIVE STRESS TO NUCLEIC ACIDS IS UNALTERED FOLLOWING RADIOIODINE THERAPY OF PATIENTS WITH BENIGN NODULAR GOITER

Bonnema SJ', Stovgaard ES ${ }^{2}$, Fast $S^{1}$, Broedbaek $K^{2}$, Andersen $\mathrm{JT}^{2}$, Grupe $P^{3}$, Hegedüs $L^{1}$, Weimann $A^{2}$, Poulsen $H^{2,4,5}$

${ }^{1}$ Odense University Hospital, Endocrinology, Odense, Denmark, ${ }^{2}$ Rigshospitalet, Laboratory of Clinical Pharmacology, Copenhagen, Denmark, ${ }^{3}$ Odense University Hospital, Nuclear Medicine, Odense, Denmark, ${ }^{4}$ Bispebjerg Hospital, Department of Clinical Pharmacology, Copenhagen, Denmark, ${ }^{5}$ University of Copenhagen, Faculty of Health Sciences, Copenhagen, Denmark

\section{P262 MANAGEMENT OF MULTINODULAR GOITERS OF ENDEMIC ZONES BY SPECIALLY TRAINED SURGEONS Maudar $K K^{1,2}$ \\ ${ }^{1}$ Bhopal Memorial Hospital and Research Centre, Surgery, Bhopal, India, ${ }^{2}$ Manipal College of Medical Sciences, Surgery, Pokhra, Nepal}

\section{P263 CALCITONIN LEVELS IN PREGNANT WOMEN}

Sanchez $E^{1}$, Grunenwald $S^{1}$, d'Herbomez $M^{2}$, Caron $P^{\prime}$

${ }^{1} \mathrm{CHU}$ Larrey, Endocrinology and Metabolic Diseases, Toulouse, France, ${ }^{2} \mathrm{CHRU}$ Lille, Department of Nuclear Medicine, Lille, France

\section{P264 LATE FOLLOW-UP RESULTS AFTER I-131 THERAPY OF TOXIC MULTINODULAR GOITER}

Petrovski $Z^{1}$

${ }^{1}$ Clinical Hospital, Department of Nuclear Medicine, Bitola, the Former Yugoslav Republic of Macedonia

\section{P265 HIGH INTENSITY FOCUSED ULTRASOUND [HIFU] - A FEASIBLE OPTION FOR THE TREATMENT OF BENIGN THYROID NODULES}

Kovatcheva $\mathrm{RD}^{1}$, Vlahov $\mathrm{JD}^{1}$, Stoinov $\mathrm{Jl}^{2}$, Ivanova $\mathrm{RS}^{3}$, Shinkov $A D^{1}$ ${ }^{1}$ University Hospital of Endocrinology, Thyroid and Metabolic Bone Diseases, Sofia, Bulgaria, ${ }^{2}$ University Hospital of Endocrinology, Endocrine Surgery, Sofia, Bulgaria, ${ }^{3}$ University Hospital of Endocrinology, Pathology, Sofia, Bulgaria

\section{P266 PREGNANCY AND EUTHYROID GOITER: CHOICE OF THERAPY \\ Badalyan $M^{1}$, Harutyunyan $A^{1}$, Azatyan $K^{2}$, Florov $V^{1}$ \\ ${ }^{1}$ Yerevan State Medical University, Yerevan, Armenia, \\ ${ }^{2}$ Polyclinic medical center N8, Yerevan, Armenia}


P030 Thyroid in Reproduction and Development Chair: Peter Bisschop, The Netherlands

\section{P267 PREDICTIVE VALUE OF MATERNAL SECOND} GENERATION TBII ASSAY FOR NEONATAL AUTOIMMUNE HYPERTHYROIDISM

Abeillon-du Payrat J ${ }^{1}$, Chikh $K^{2,3}$, Bossard $N^{4}$, Bretones $P^{5}$, Gaucherand $P^{6,7}$, Claris $O^{7,8}$, Charrié $A^{2,9}$, Raverot $V^{10}$, Orgiazzi $\mathrm{J}^{7,11}$, Borson - Chazot $F^{7,12,13}$, Bournaud $C^{7,13,14}$ ${ }^{1}$ Hospices Civils de Lyon, GH Est, Fédération d'endocrinologie, Bron Cedex, France, ${ }^{2}$ Hospices Civils de Lyon, Centre Hospitalier Lyon Sud, Service de biochimie, Lyon, France, ${ }^{3}$ Faculté de pharmacie, Lyon, France, ${ }^{4}$ Hospices Civils de Lyon, Service de biostatistiques, Lyon, France, ${ }^{5}$ Hospices Civils de Lyon, GH Est, Service d'endocrinologie pédiatrique, Lyon, France, ${ }^{6}$ Hospices Civils de Lyon, GH Est, Service de gynécologie obstétrique, Lyon, France, ${ }^{7}$ Université Lyon 1, Faculté de médecine Lyon Est, Lyon, France, ${ }^{8}$ Hospices Civils de Lyon, GH Est, Service de néonatologie, Lyon, France, ${ }^{9}$ Faculté de médecine et de maïeutique Lyon Sud, CARMEN INSERM U1060, Lyon, France, ${ }^{10}$ Hospices Civils de Lyon, GH Est, Service de biochimie, Lyon, France, ${ }^{11}$ Hospices Civils de Lyon, Centre hospitalier Lyon Sud, Service d'endocrinologie, Lyon, France, ${ }^{12}$ Hospices Civils de Lyon, GH Est, Fédératoion d'endocrinologie, Lyon, France, ${ }^{13}$ INSERM, U1052, Lyon, France, ${ }^{14}$ Hospices Civils de Lyon, GH Est, Service de Médecine nucléaire, Lyon, France

\section{P268 EFFECTS OF IODINE SUPPLEMENTATION ON THYROID FUNCTION IN INFANTS}

Belykh $N A^{1}$, Mamenko $\mathrm{MY}^{1}$, Dontsova $E M^{1}$

${ }^{1}$ Luhansk State Medical University, Department of

Postgraduate Education of Pediatrics, Lugansk, Ukraine

\section{P269 SUBCLINICAL HYPOTHYROIDISM IN PREGNANCY:} 5 YEAR FOLLOW-UP INDICATES THE MAJORITY OF CASES ARE TRANSIENT

Shields $B M^{1}$, Knight $B A^{1}$, Hill $A V^{1}{ }^{1}$, Hattersley $A T^{1}$, Vaidya $B^{1,2}$ ${ }^{1}$ University of Exeter Medical School, Exeter, United Kingdom, ${ }^{2}$ Royal Devon \& Exeter Hospital, Endocrinology, Exeter, United Kingdom

\section{P270 EFFECTS OF IODINE SUPPLEMENTATION ON PREGNANCY AND ON THE OFFSPRING}

Mamenko $\mathrm{M}^{1}$, Belykh $N^{1}$, Valiyev $\mathrm{O}^{2}$, Mimyaylo $\mathrm{N}^{3}$, Kovalenko $\mathrm{N}^{4}$ ${ }^{1}$ Luhansk State Medical University, Department of

Postgraduate Education of Pediatrics, Lugansk, Ukraine, ${ }^{2}$ Luhansk State Medical University, Obstetrics and Gynecology, Luhansk, Ukraine, ${ }^{3}$ Krasnodon Obstetrics Hospital, Krasnodon, Ukraine, ${ }^{4}$ Pervomaysk Obstetrics Hospital, Pervomaysk, Ukraine
P271 IODINE PROPHYLAXIS RATHER THAN L-THYROXINE TREATMENT IS EFFECTIVE IN IMPROVING NEUROINTELLECTUAL PERFORMANCES IN CHILDREN BORN TO MOTHERS FROM A MODERATELY IODINE DEFICIENT (ID) AREA: RESULTS OF A LONGITUDINAL PILOT STUDY Moleti $M^{1}$, Ilardo $G^{2}$, Boncoddo $M^{2}$, Candia Longo $A^{2}$, Di Bella $B^{1}$, Presti $S^{1}$, Sturniolo $G^{1}$, Tortorella $G^{2}$, Trimarchi $F^{1}$, Vermiglio $F^{1}$ ${ }^{1}$ University of Messina, Endocrinology, Messina, Italy,

${ }^{2}$ University of Messina, Neuroscience, Messina, Italy

P272 CROSS-CULTURAL VALIDITY OF THE THYROIDRELATED QUALITY OF LIFE INSTRUMENT THYPRO

Watt $T^{1}$, Barbesino $G^{2}$, Bjorner $J B^{3}$, Bonnema $S J^{4}$, Bukvic $B^{5}$, Drummond $R^{6}$, Groenvold $M^{3}$, Hegedüs $L^{4}$, Kantzer $V^{7}$, Lasch $K E^{8}$, Marcocci $C^{9}$, Mishra $A^{10}$, Netea-Maier $R^{11}$, Paunovic ${ }^{12}$, Quinn $T^{6}$, Åse $R K^{13}$, Russell $A^{14}$, Sabaretnam $M^{15}$, Smit JWA ${ }^{16}$, Törring $\mathrm{O}^{17}$, Zivaljevic $V^{12}$, Feldt-Rasmussen $U^{13}$

${ }^{1}$ Copenhagen University Hospital Rigshospitalet, Department of Medical Endocrinology, Copenhagen, Denmark, ${ }^{2}$ Massachusetts General Hospital, Boston, United States, ${ }^{3}$ University of Copenhagen, Copenhagen, Denmark, ${ }^{4}$ Odense University Hospital, Odense, Denmark, ${ }^{5}$ University of Belgrade, Belgrade, Serbia, ${ }^{6}$ University of Glasgow, Glasgow, United Kingdom, ${ }^{7}$ Health Research Associates, Seattle, United States, ${ }^{8}$ Pharmerit, Boston, United States, ${ }^{9}$ University of Pisa, Pisa, Italy, ${ }^{10}$ Sanjay Gandhi Postgraduate Medical Institute, Lucknow, India, ${ }^{11}$ University Nijmegen Medical Center, Nijmegen, Netherlands, ${ }^{12}$ Clinical Centre of Serbia, Belgrade, Serbia, ${ }^{13}$ Copenhagen University Hospital (Rigshospitalet), Copenhagen, Denmark, ${ }^{14}$ University of Cork, Cork, Ireland, ${ }^{15}$ Christian Medical College, Vellore, India, ${ }^{16}$ Nijmegen University Medical Center, Nijmegen, Netherlands, ${ }^{17}$ Karolinska Institutet, Stockholm, Sweden

P273 IODINE SUPPLEMENTATION DURING PREGNANCY AND OFFSPRING NEUROCOGNITIVE DEVELOPMENT AT 2 YEARS OF AGE IN AN AREA OF MILD IODINE DEFICIENCY Brucker-Davis $F^{1}$, Chauliac $F^{2}$, Panaia-Ferrari $P^{3}$, Fenichel $P^{1}$, Hieronimus $S^{1}$

${ }^{1} \mathrm{CHU}$ Nice, Endocrinology, Nice, France, ${ }^{2} \mathrm{CHU}$ Nice, Neurology, Nice, France, ${ }^{3} \mathrm{CHU}$ Nice, Biochemistry, Nice, France

\section{P274 IODINE STATUS AMONG PREGNANT PATIENTS IN NORTH-EAST OF TURKEY, TRABZON, AFTER MANDATORY SALT IODINATION}

Anaforoglu I', Algun $\mathrm{E}^{1}$, Incecayır $\mathrm{O}^{1}$, Topbas $\mathrm{M}^{2}$, Erdogan $\mathrm{MF}^{3}$

${ }^{1}$ Trabzon Kanuni Education and Research Hospital, Endocrinology and Metabolism, Trabzon, Turkey, ${ }^{2}$ Karadeniz Technical University, Faculty of Medicine, Department of Public Health, Trabzon, Turkey, ${ }^{3}$ Ankara University, Faculty of Medicine, Endocrinology and Metabolism, Ankara, Turkey

\section{P275 THE RELATION OF THYROID STIMULATING HORMONE AND METABOLIC PARAMETERS IN THE SUBJECTS FOR HEALTH CHECK-UP}

Yu $\mathrm{HM}^{1}$, Park $K S^{1}$, Lee $J M^{1}$, Hong $J H^{1}$, Ryu $A J^{1}$

${ }^{1}$ Research Institute of Clinical Medicine, Eulji University Hospital, Division of Endocrinology and Metabolism, Department of Internal Medicine, Daejeon, Republic of Korea 


\section{Congress General Information}

\section{Venue}

City Music Hall (Stadsgehoorzaal)

Breestraat 60

2311 CS Leiden, The Netherlands

Tel. +319009001705

All conference rooms are fully equipped with up-to-date presentation systems. Powerpoint is the preferred format for presentations.

In the Media Check Room speakers can also check their presentation at several working stations.

\section{Opening Times of Media Check}

$\begin{array}{ll}\text { Saturday: } & 07.30-18.30 \\ \text { Sunday: } & 07.30-19.00 \\ \text { Monday: } & 07.30-17.30 \\ \text { Tuesday: } & 07.30-18.00 \\ \text { Wednesday: } & 07.30-12.30\end{array}$

All presenters are requested to hand in their lecture at least 1 hour before the scheduled talk, or the day before if your talk is early the next morning.

\section{Poster Displays}

Maximum Poster sizes are $125 \mathrm{~cm}$ high and $90 \mathrm{~cm}$ wide. The poster should be easily readable from a distance of about $1 \mathrm{~m}$. All posters have to be in English.

Mounting material will be available on site. All poster boards will be numbered. Staff will assist you in locating your poster wall and setting up your poster.

Poster discussion sessions are from 12.00-13.00 from Sunday to Tuesday. Your poster should be in place well before discussion time. See below for a time guide:

P1-P94: $\quad$ Sunday 8 th from 07.30 to be removed by 18.00

P95-P183: $\quad$ Monday 9th from 07.30 to be removed by 17.00

P184-P275: Tuesday 10 th from 07.30 to be removed by 18.00

\section{Authors must be present at their poster session.}

Thank you for your understanding that posters not removed by the above mentioned times cannot be stored.

\section{Programme Changes}

The organisers do not assume liability for any changes in the programme due to external or unforeseen circumstances. 
The official congress language is English.

\section{Name Badges}

Entrance to the Congress area will be limited to badge holders only. If the badge is lost, please contact the Congress registration desk.

\section{Congress Lunches}

Lunch boxes will be provided in the exhibition areas as well as two other catering stations within the venue (see floor plans).

\section{Coffee Breaks}

Coffee breaks will be served in the exhibition areas as well as at various stations within the venue. The coffee bar in the Catherina Foyer is a self-paying bar which only offers free coffee during the official coffee breaks.

\section{Congress Material}

The Congress participants who have pre-registered will receive the congress material, together with their name badge from the Pre-Registered desk of the Congress Secretariat.

\section{Banks and Exchange}

Banks are open from Monday to Friday, from 9.00-17.00 and are closed on public holidays. Most hotels, restaurants and shops accept credit cards. ATMs are located throughout the city.

\section{Climate}

The Netherlands is located in a temperate weather region with moderate temperatures. Early September should still be relatively warm.

\section{Currency}

The official currency in the Netherlands is the Euro.

\section{Dutch Time}

Leiden is located in the Central European Time Zone $(G M T+1)$. During the congress the official time will be summer time, i.e. GMT +2 .

\section{Electricity}

The electricity supply is 220 volts. Foreign appliances may require a power converter and/or an adapter.

\section{Emergency phone numbers}

For emergencies dial 112. 
Health

Free first aid and hospital services are available to all citizens of the Europe who have a special card (EHIC, European Health Insurance Card, formerly E111) issued by the health authority of the relative country. Visitors from other countries are advised to take out special insurance for the duration of the trip, to avoid the cost of possible medical treatment. American visitors may find that reimbursement of medical expenses incurred abroad is covered by their private insurance. Prescription medication can only be obtained in the pharmacies (Apotheek).

\section{Insurance}

The registration fee does not include the insurance of participants against personal accidents, illness, cancellations by any party, loss or damage to personal possessions, theft. All participants are strongly advised to make adequate personal insurance arrangements to cover travel, accommodation, cancellation and personal effects prior to travel.

\section{Italian Secretariat}

Alijet \& Fargo International S.r.I. has been appointed to be the referent between the Italian Pharmaceutical Companies and the Italian Health Ministry as to the collection and submission of the legal documentation required by the Italian Legislative Order n. 219 of 24th April 2006 - art. 124 from Italian delegates visiting the congress. Contact: Alijet \& Fargo International S.r.l., Via Pietro Maroncelli 44/46, 50137 Firenze, Italy, Tel. 01139055600555 - Fax 01139055609078.

\section{Smoking Policy}

For the general comfort and health of all participants, smoking is not permitted at any of the official functions during the Congress. This includes all scientific sessions, business and other meetings, evening functions and registration area \& foyers.

\section{Telephone}

The international code for The Netherlands is ++31 . The prefix for Leiden is (0)71.

\section{Tipping}

Value-added tax (VAT) and service charges are included in hotel, restaurant, shopping bills and taxi fares. Tips for extra services are always appreciated but not absolutely necessary. It is customary to give taxi drivers and waiters a tip of about 10 per cent.

\section{Visa Requirements}

Citizens of countries in the European Union and the European Economic Area do not need a visa for The Netherlands.

We advise you to consult the following website:

http://www.justlanded.com/english/Netherlands/Netherlands-Guide/Visas-Permits/ Visa-requirements for updated and detailed information for foreigners regarding entrance visas for The Netherlands and permits of stay. Foreign participants should contact the Dutch Embassy or Consulate in their home country as soon as possible to determine their particular visa requirements. Participants requiring visas must initiate the application process at least 3 months prior to their departure date. Visa 
application procedures are easier when the confirmation of registration is included.

Refunds cannot be made if a visa application is not granted.

The conference organizers are not obliged to assist participants with their visa application process.

\section{Leiden Information}

Leiden can be reached easily by international visitors, with Schiphol just 20 minutes away and Rotterdam's smaller airport at 25 minutes distance. Leiden is within 10 kilometres of Holland's North Sea coast, and the Green Heart of the Netherlands is also close at hand.

Leiden is ideally located within a short travelling distance of major centres such as The Hague and Amsterdam.

By car

Leiden is located between the A4 and A44 motorways, which makes it easy to reach by car. The city centre is a pedestrian-only area, but visitors will find space for more than 3,000 cars in the many small and large car parks and garages spread around the periphery of the centre.

\section{Haagweg car park (recommended for visitors)}

Leiden's biggest car park is on the Haagweg, and provides full park-and-ride services to the city centre. During the daytime and in the evenings, shuttle buses will take you from the car park to all the main spots in the city - and bring you back, of course. Special arrangements can be made for groups, so that you can always be sure of transport to the city centre. For more information: www.stadsparkeerplan.com.

\section{Cycling in and around Leiden}

As well as the city centre, the area around Leiden also has a lot to offer. Cycling is the ideal mode of transport for discovering the region, and there are many different cycle routes starting in Leiden see http://portal.leiden.nl/en/tourism_leisure/discover/ walking_and_cycling

\section{Bicycle Rental Leiden}

De Rijwielshop, at the rear of the main station.

See further information under Transportation.

\section{Airports}

\section{Amsterdam Airport/AMS (http://www.amsterdamairport.info/)}

Officially known by the name Amsterdam Airport Schiphol, this airport is of great importance in Europe. It is an international airport and is located 20 minutes from Amsterdam city and approximately 9 miles south-west of the center of Amsterdam in Haarlemmermeer municipality. This is an international airport connecting to many notable European airports.

\section{Rotterdam Airport/RTM (http://rotterdam-rtm.airports-guides.com/)}

Rotterdam Airport is a small airport that handles flights from a small number of local carriers to destinations throughout Europe. The airport is situated around $8 \mathrm{~km} /$ 5 miles to the north-west of central Rotterdam and close to Kethel, Schiebroek, Schiedam and Zestienhoven. 


\section{Transportation}

Leiden can be reached in a variety of ways: by car, boat, train, bus and by air. At Amsterdam (Schiphol) and Rotterdam Airport, flights are continually landing from the major cities of neighbouring countries. The number of international flights is increasing.

Inside the city, a network of busses, maintains excellent connections. Parking places for coaches can be found, for example, near Municipal Windmill Museum 'De Valk'. Trains from all directions stop at Leiden Central Station, and the city centre is just a short walk from the station. Or, if you prefer, there is a frequent bus service from the station to almost anywhere in the city.

See also http://portal.leiden.nl/en/tourism_leisure/practical/accessibility

\section{Bus}

Connexxion Stationsplein 3F (at AKO at Leiden Central Station), 2312 AJ Leiden, customer service tel. 0900-2666399 Veolia Transport Haaglanden/Service point Zoetermeer, Kelvinstraat 52723 RJ Zoetermeer

\section{Train}

Dutch Railways www.ns.nl

Information OV Chipkaart: www.ov-chipkaart.nl

\section{Taxi Information}

Taxi stands

Stations: Leiden Central, Leiden Lammenschans

\section{Information about the Netherlands}

For further information about the Netherlands please visit www.holland.com 


\section{European Thyroid Journal}
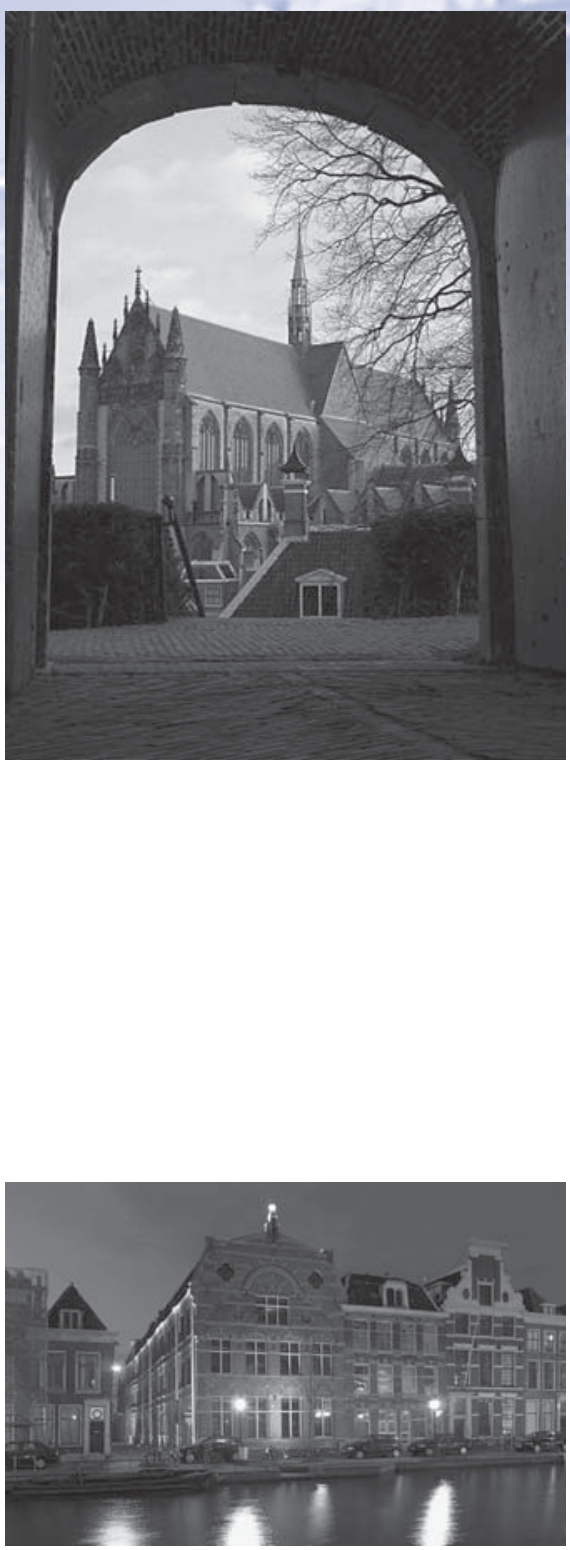

Photo: Courtesy of Scheltema Leiden

\section{Social Events}

\section{Welcome Reception}

Saturday, 7th September, 19.30-21.00

\author{
Hooglandse Kerk (Highlands Church) \\ Middelweg 2 \\ 2312 KH Leiden
}

The Hooglandse Kerk is a cross-shaped church dating from the 14th century. Although emptied of its art by Calvinist iconoclasm, its elegant architecture has been beautifully restored. The first place of worship on this elevated site was a simple wooden chapel consecrated to St. Pancras around the beginning of the 14th century. In 1315, it was replaced by a sturdier stone church, and in 1377 construction of the present Late Gothic church got underway, beginning with the choir. The Collegiate Church of St. Pancras was consecrated in phases in 1381 and 1436. Other buildings sprung up around the church in this period, including homes for the canons, a beguinage, and an inn. The Hooglandse Kerk is located where the Old Rhine and New Rhine rivers meet. A beautiful landmark of Leiden. For further information go to www.hooglandsekerk.com. After the welcome address from Jan Smit and Theo Visser, you will be able to enjoy a short organ concert before the buffet opens. The Hooglandse Kerk is within walking distance of the congress venue.

Price per person: included in the fee for registered participants and registered accompanying persons.

\section{ETA Excursion: Canal Trip and Scheltema Complex, Marktsteeg 1}

\section{Monday, 9th September, 18.00}

The excursion will be an impressive encounter with past and present of Leiden. A canal tour through the beautiful Leiden canals will be held with small motorboats http://www.schuitjevaart.nl/e_index.html. For those of you who prefer a more stable ride, a guided city walking tour will be provided. After the canal tour, all will meet at the Scheltema complex (Marktsteg 1) http://www. scheltemaleiden.nl/Historie (Dutch language only) which originally housed a factory of sheets and plaids. After the factory was closed, the building was renovated into a cultural center, where modern art and science meet in exhibitions, performances and symposia. No better place for thyroid scientists to meet! We will have an informal party at Scheltema with typical Dutch food, drinks and dance. The boats for the canal tour will leave from the canal directly behind the congress venue, within walking distance.

NB: Drinks are complimentary from 19.00-22.00 only. Any drinks consumed after 22.00 must be paid for by the participant.

\section{Price per person: $50 €$}


Gala Dinner: National Museum of Antiquities, Rapenburg 28, Leiden

\section{Tuesday, 10th September, 20.00}

The formal congress dinner will be in the National Museum of Antiquities, http://www.rmo.nl/english, Rapenburg 28, Leiden. The Museum hosts an internationally renowned collection of fine Egyptian, Greek and Roman art and archeology as well as remains from ancient Dutch history. The dinner will be at the main hall in the museum where the Temple of Taffeh, transported piece by piece from Nubia will ensure a stylish atmosphere. During the evening, the collection can be visited. This venue is in the old city centre.

Price per person: $75 €$ (formal dress)
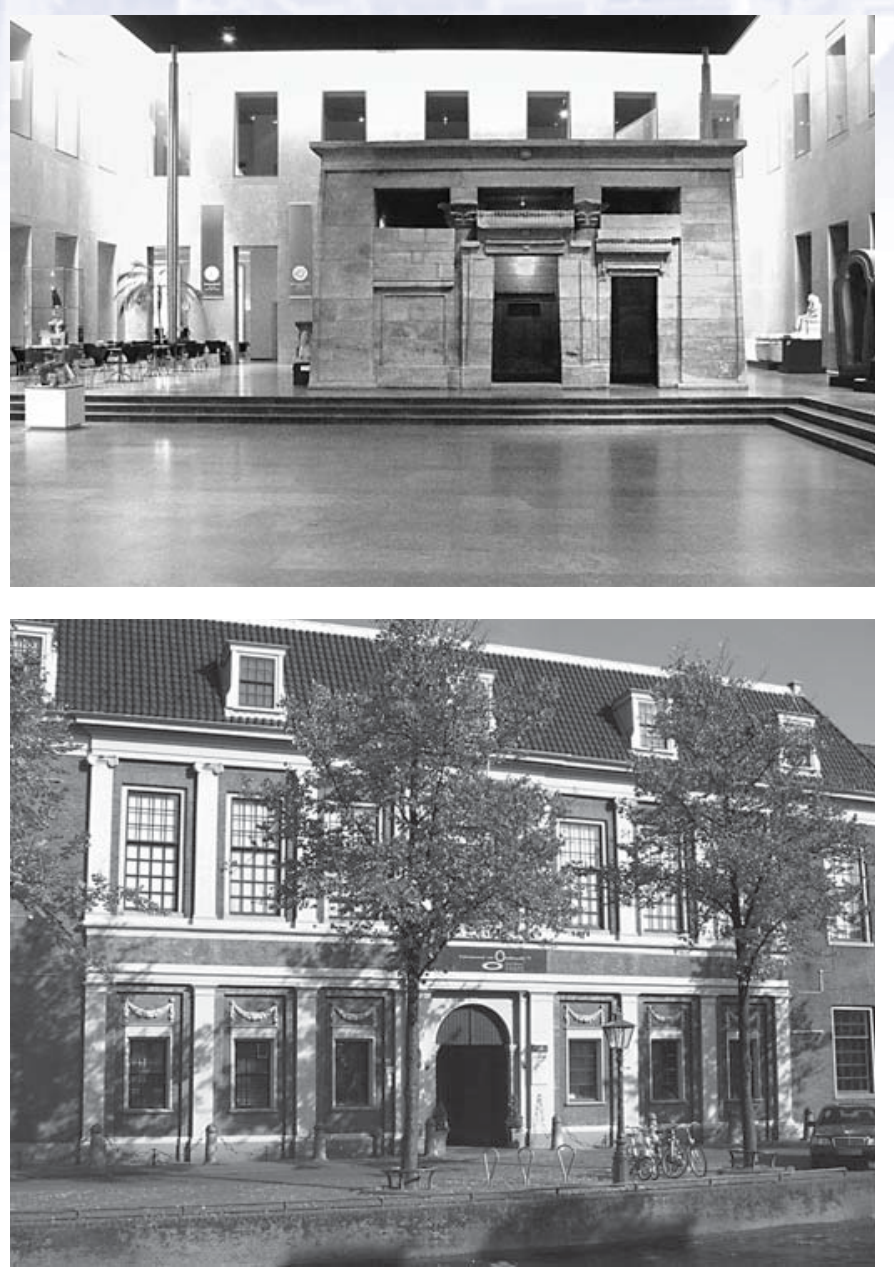

Photo: Courtesy of the Rijksmuseum van Oudheden 


\section{European Thyroid Journal}

\section{Map of Leiden}

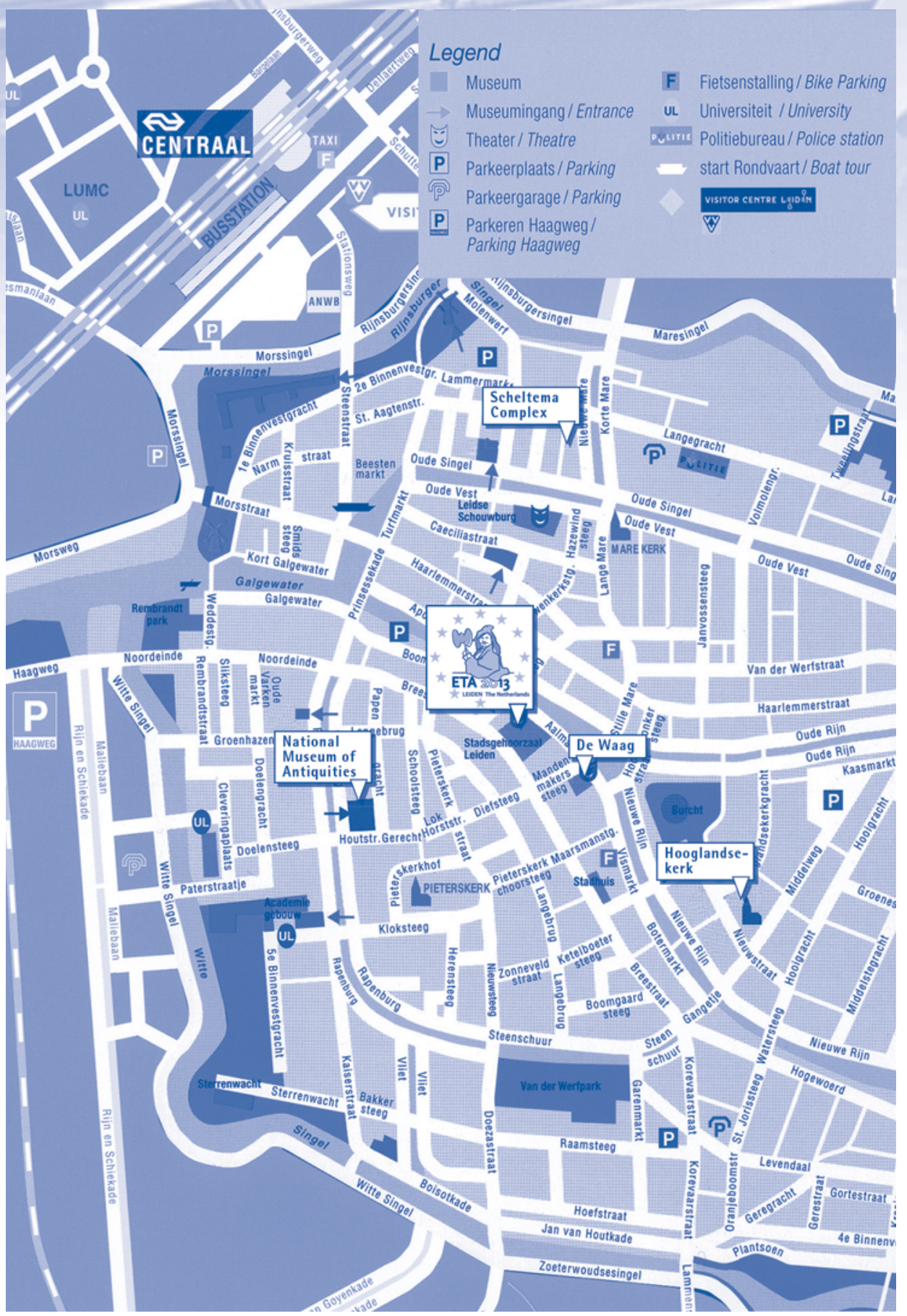




\section{Transparency Declaration}

The Executive Committee and the Standing Office of the ETA are most grateful to the following ETA Corporate members and all other sponsors for their generous logistical support of the ETA 2013 Annual Meeting

\begin{tabular}{|c|c|}
\hline AstraZeneca & $\begin{array}{l}30,000 € \text { for a satellite symposium } \\
6,000 € \text { for an exhibition booth } \\
1,500 € \text { for a one page advert }\end{array}$ \\
\hline Bayer Healthcare Pharmaceuticals & $\begin{array}{l}30,000 € \text { for a satellite symposium } \\
7,500 € \text { for an exhibition booth } \\
1,500 € \text { for a one page advert }\end{array}$ \\
\hline Eisai Europe Limited & $\begin{array}{l}30,000 € \text { for a satellite symposium } \\
1,500 € \text { for a one page advert }\end{array}$ \\
\hline Esaote SpA & $\begin{array}{l}1,200 \text { lanyards } \\
3,000 € \text { for an exhibition booth }\end{array}$ \\
\hline Esaote Benelux & 2 Ultrasonic scanners \\
\hline Exelixis, Inc. & $3,000 €$ for an exhibition booth \\
\hline Genzyme Europe bv & $\begin{array}{l}30,000 € \text { for a satellite symposium } \\
1,500 € \text { for a one page advert } \\
9,000 € \text { for an exhibition booth }\end{array}$ \\
\hline inomed Medizintechnik GmbH & Exhibition booth \\
\hline Merck Serono & $\begin{array}{l}10,000 € \text { for congress bags } \\
30,000 € \text { for a satellite symposium } \\
15,000 € \text { for an exhibition booth } \\
\text { Internet Café } \\
1,000 \text { writing pads and } 100 \text { pens }\end{array}$ \\
\hline Oxigene, Inc. & $3,000 €$ for an exhibition booth \\
\hline Pfizer bv & $\begin{array}{l}1,000 \text { congress pens } \\
2,000 € \text { for an exhibition booth }\end{array}$ \\
\hline Philips, The Netherlands & $\begin{array}{l}2 \text { Ultrasonic scanners } \\
1,000 € \text { for an exhibition booth }\end{array}$ \\
\hline Roche Diagnostics International Ltd. & $6,000 €$ for an exhibition booth \\
\hline Theraclion SA & $3,000 €$ for an exhibition booth \\
\hline Thermo Fisher Scientific & $7,500 €$ for an exhibition booth \\
\hline WON TECH Co., Ltd. & $3,000 €$ for an exhibition booth \\
\hline
\end{tabular}

